\title{
Halogen-Bonding Interactions and Electrochemical Properties of Unsymmetrical Pyrazole Pincer Ni" Halides: A Peculiar Behavior of the Fluoride Complex (PCN)NiF
}

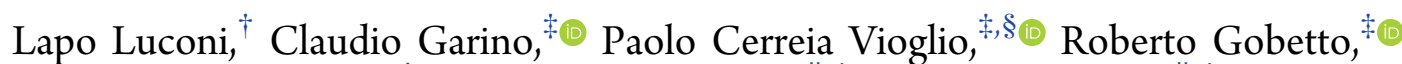

Michele R. Chierotti, ${ }^{*}$, Dic Ditry Yakhvarov, ${ }^{*}, \|, \perp$ Zufar N. Gafurov, ${ }^{\|, \perp}$ Vladimir Morozov, ${ }^{\perp}$

Il'yas Sakhapov, $^{\perp}$ Andrea Rossin, ${ }^{*} \dagger$ (i) and Giuliano Giambastiani ${ }^{*}, \dagger, \| \oplus$

${ }^{\dagger}$ Istituto di Chimica dei Composti Organometallici (ICCOM-CNR), Via Madonna del Piano 10, 50019 Sesto Fiorentino, Italy

${ }^{\ddagger}$ Department of Chemistry and NIS Centre, University of Torino, V. Giuria 7, 10125 Torino, Italy

${ }^{\S}$ CNRS, Aix-Marseille Université, Institute de Chimie Radicalaire, Avenue Escadrille Normandie-Niemen 521, 13397 Marseille, France

"Kazan Federal University, Kremlyovskaya str. 18, 420008 Kazan, Russia

${ }^{\perp}$ Arbuzov Institute of Organic and Physical Chemistry, FRC Kazan Scientific Center of RAS, Arbuzov str. 8, 420088 Kazan, Russia

Supporting Information

ABSTRACT: Four metal halides of the $\left({ }^{t \mathrm{Bu}} \mathrm{PCN}\right) \mathrm{NiX}$ family $[\mathrm{X}$ $=\mathrm{F}(1), \mathrm{Cl}(2), \mathrm{Br}(3)$, or I (4); $\mathrm{PCN}=1-[3-[($ di-tertbutylphosphino)methyl]phenyl]-1H-pyrazole] have been prepared through a direct reaction of the corresponding anhydrous $\mathrm{NiX}_{2}$ salts and the unsymmetrical PCN pincer ligand. Structural information from single-crystal X-ray data, ${ }^{19} \mathrm{~F}$ solution nuclear magnetic resonance, and combined electrochemical results [cyclic voltammetry $(\mathrm{CV})$ and in situ electron paramagnetic resonance spectro-electrochemistry] reveal that the fluoride complex $\mathbf{1}$ is different from the other halides $\mathbf{2 - 4}$ in terms of electro-oxidation behavior (presence of three anodic peaks instead of one in the CV profile). $\mathbf{1}$ is also different from its symmetrical analogue $\left({ }^{t \mathrm{Bu}} \mathrm{PCP}\right) \mathrm{NiF}$ in terms of halogen-bonding capability toward the halogen-bond donor, iodopentafluorobenzene $\left(\mathrm{C}_{6} \mathrm{~F}_{5} \mathrm{I}, \mathrm{IPFB}\right)$. The positive $\Delta S^{\circ}$ value for the formation of the 1 ...IPFB adduct inferred from the van't Hoff plots is in agreement with the existence of $\left(\mathbf{1} \cdot \mathrm{H}_{2} \mathrm{O}\right)$ aggregates in solution, not present in $\mathbf{2}-\mathbf{4}$. The high nucleophilicity of the fluoride ligand and the simultaneous presence of electrophilic (acidic) protons on the sidearm of the pyrazole ligand are at the origin of the observed phenomena.

\section{INTRODUCTION}

Intermolecular interactions such as hydrogen and halogen bonding have found applications in various fields of chemistry and interdisciplinary sciences. ${ }^{1-7}$ Over the past decade, the study of halogen bonding in particular has undergone dramatic development. It has emerged as a powerful, directional, and selective noncovalent force in molecular recognition, supramolecular assembly, materials chemistry, and structural biology. ${ }^{8-15}$ Halogen bonding typically involves a Lewis acidic, covalently bound halogen and a Lewis basic site. It is commonly observed for the heavier halogen iodine, where its lower electronegativity and higher polarizability facilitate the redistribution of the electron density when the halogen is involved in covalent bonds, ${ }^{16}$ thereby yielding an electrondeficient region aligned along the covalent bond. This region of positive electrostatic potential is called " $\sigma$-hole," enhanced by the presence of an electron-withdrawing group bound to iodine. Thus, iodopentafluorobenzene $\left(\mathrm{C}_{6} \mathrm{~F}_{5} \mathrm{I}\right.$, IPFB)

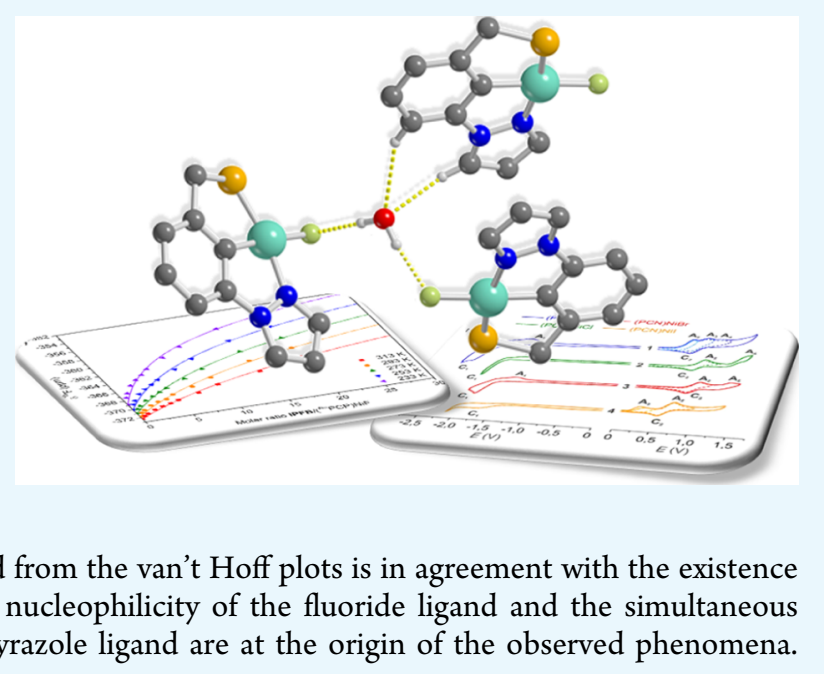

is a better halogen-bond donor than the simple iodobenzene $\left(\mathrm{C}_{6} \mathrm{H}_{5} \mathrm{I}\right)$, owing to the strong electron-withdrawing inductive effect of fluorine on the aromatic ring. From the halogen-bond acceptor side, transition metal fluorides have been analyzed as candidates in recent years by a number of seminal studies. They have been extensively studied to elucidate their unusual reactivity and their role in $\mathrm{C}-\mathrm{F}$ activation and $\mathrm{C}-\mathrm{F}$ bond formation processes. ${ }^{18-23}$ Indirect evidence based upon complexes of other metal halides ${ }^{24,25}$ and upon simple fluoride ions $^{26,27}$ suggests that fluoride ligands may serve as halogenbond acceptors. Indeed, metal fluoride complexes are today recognized as good acceptors of both hydrogen and halogen bonds. $^{28-32}$ Among the various $3 \mathrm{~d}$ transition metal complex fluorides conceivable, those of nickel play a predominant role.

Received: September 20, 2018

Accepted: December 20, 2018

Published: January 14, 2019 
In fact, synthesis and characterization of organometallic highvalent nickel species is of great importance as they have been widely proposed as key intermediates in carbon-carbon and carbon-heteroatom bond formation reactions. ${ }^{33-36}$ Ligand design turns out to play a vital role in determining the stability and reactivity of the corresponding $\mathrm{Ni}$ centers. However, the generation of high metal oxidation states (such as $\mathrm{Ni}^{\mathrm{III}}$ or $\mathrm{Ni}^{\mathrm{IV}}$ ) and related complexes is not easy using classical pathways but can be achieved through electrochemical methods. In this context, the study of electrochemical properties and mechanism of redox processes of these organometallic species is of great interest. Following our investigation on novel unsymmetrical pincer-type complexes containing the pyrazole-based $\kappa^{3}$-tridendate ligand ${ }^{t \mathrm{Bu}} \mathrm{PCN}(\mathrm{H})\{1-[3-[($ di-tertbutylphosphino)methyl $]$ phenyl $]-1 H$-pyrazole, Scheme 1$\},{ }^{37}$

Scheme 1. (a) Synthesis of $\left({ }^{t \mathrm{Bu}} \mathrm{PCN}\right) \mathrm{NiX}(\mathrm{X}=\mathrm{Cl}, \mathrm{Br}$, or I); (b) Synthesis of $\left({ }^{t \mathrm{Bu}} \mathrm{PCN}\right) \mathrm{NiF}$

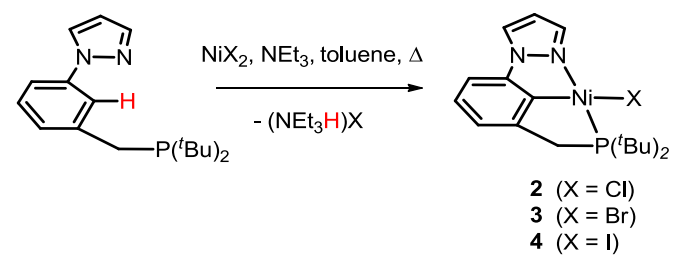

(a)

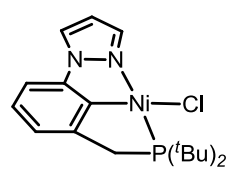

2

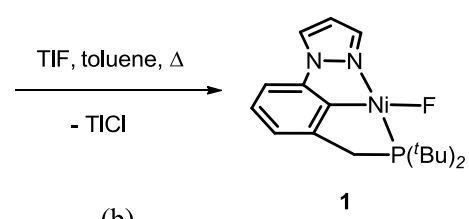

(b) we have prepared and characterized the nickel(II) halide series $\left({ }^{t \mathrm{Bu}} \mathrm{PCN}\right) \mathrm{NiX}(\mathrm{X}=\mathrm{F}, \mathrm{Cl}, \mathrm{Br}$, or I. Scheme 1$)$. The fluoride complex $\left({ }^{\mathrm{t} u} \mathrm{PCN}\right) \mathrm{NiF} \mathbf{1}$ has been compared with its symmetrical analogue $\left({ }^{t \mathrm{Bu}} \mathrm{PCP}\right) \mathrm{NiF}^{38}$ in terms of halogenbonding capability toward IPFB. In the previous study carried out by some of us on $\left({ }^{t B u} \mathrm{PCP}\right) \mathrm{NiF},{ }^{29}$ the high nucleophilicity of the fluoride ligand and its hydrogen-bonding ability toward the acidic transition metal hydride $\mathrm{CpW}(\mathrm{CO})_{3} \mathrm{H}\left(\mathrm{Cp}=\eta^{5}\right.$ $\left.\mathrm{C}_{5} \mathrm{H}_{5}{ }^{-}\right)$have been unveiled and analyzed in detail through ${ }^{19} \mathrm{~F}$ and ${ }^{1} \mathrm{H}$ nuclear magnetic resonance (NMR) spectroscopies. In here, we present the extension of this chemistry to halogen bonding toward IPFB. Finally, the combined structural (X-ray crystal structure), spectroscopic [variable temperature (VT) ${ }^{19} \mathrm{~F}$ NMR and electron paramagnetic resonance (EPR)], and electrochemical [cyclic voltammetry $(\mathrm{CV})$ ] information on $\mathbf{1}$ has confirmed its special behavior when compared with $\left({ }^{t \mathrm{Bu}} \mathrm{PCP}\right) \mathrm{NiF}$ or other complex halides of the $\left({ }^{t \mathrm{Bu}} \mathrm{PCN}\right) \mathrm{NiX}$ series.

\section{RESULTS AND DISCUSSION}

2.1. (PCN) Pincer Nickel(II) Halide Synthesis and Characterization. Following the same experimental procedure reported in the literature for the preparation of symmetrical nickel pincer complexes, ${ }^{39}$ the $\left({ }^{t \mathrm{Bu}} \mathrm{PCN}\right) \mathrm{NiX}[\mathrm{X}$ $=\mathrm{Cl}(2), \mathrm{Br}$ (3), I(4)] compounds were straightforwardly obtained through a direct reaction of the corresponding anhydrous $\mathrm{NiX}_{2}$ salts with the asymmetric pincer ligand ${ }^{t \mathrm{Bu}} \mathrm{PCN}(\mathrm{H})^{37}$ in toluene at reflux for $24 \mathrm{~h}$ (Scheme 1a). The $\mathrm{HX}$ byproduct is trapped by the addition of trimethylamine, with the concomitant formation of the related $\left(\mathrm{NEt}_{3} \mathrm{H}\right) \mathrm{X}$ ammonium salt that precipitates out of the reaction mixture. As previously reported by some of us for the synthesis of $\left({ }^{t \mathrm{Bu}} \mathrm{PCP}\right) \mathrm{NiF},{ }^{38}$ the fluoro-complex $\left({ }^{t \mathrm{Bu}} \mathrm{PCN}\right) \mathrm{NiF}(\mathbf{1})$ is obtained from chloro-analogue 2 after treatment with thallium fluoride in methanol (Scheme 1b). The driving force for the halide abstraction reaction is provided by the formation of the insoluble $\mathrm{TlCl}$ that is easily separated from the supernatant through filtration.

Complexes 1-4 were isolated in the form of air-stable yellow powders; they were characterized both in solution (multinuclear ${ }^{1} \mathrm{H},{ }^{13} \mathrm{C}\left\{{ }^{1} \mathrm{H}\right\}$, and ${ }^{31} \mathrm{P}\left\{{ }^{1} \mathrm{H}\right\}$ NMR spectroscopy) and in the solid state (single-crystal X-ray diffraction analysis). In $\mathrm{CD}_{2} \mathrm{Cl}_{2}$, the ${ }^{1} \mathrm{H}$ chemical shift of the acidic pyrazole proton closer to the metal center $[\mathrm{H}(8)$-Experimental Section] follows an increasing trend when passing from $1\left(\delta_{\mathrm{H}}=7.58\right.$ $\mathrm{ppm})$ to $2\left(\delta_{\mathrm{H}}=7.86 \mathrm{ppm}\right), 3\left(\delta_{\mathrm{H}}=8.13 \mathrm{ppm}\right)$, and $4\left(\delta_{\mathrm{H}}=\right.$ $8.47 \mathrm{ppm})$, in line with the decreased mesomeric effect $(+\mathrm{R})$ of the corresponding halide ligand. The same trend is observed in the ${ }^{31} \mathrm{P}$ NMR chemical shifts of the coordinated phosphorus atom $\left(\delta_{\mathrm{P}}=86.1,87.3,88.7\right.$, and $91.7 \mathrm{ppm}$ for 1, 2, 3, and 4, respectively). 1 and 4 crystallize in the $P 2_{1} / n$ monoclinic space group, with four molecules per unit cell, whereas 2 and 3 are isostructural and crystallize in the $\bar{P} \overline{1}$ triclinic space group, with two molecules per unit cell. In all cases, the coordination geometry around the metal center is square planar (Figure 1),

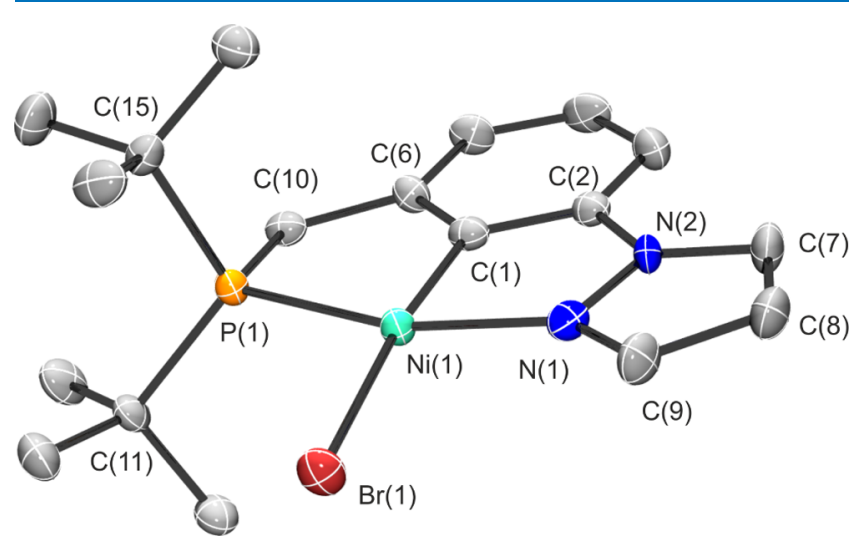

Figure 1. ORTEP thermal ellipsoid plot diagram (ellipsoids at 50\% probability) of the structure of 3 as a representative example of the family. Hydrogen atoms on the ligand omitted for clarity.

with the halide ligand occupying the coordination site trans to the pincer ipso carbon. The phosphorus atom and one nitrogen atom from the pyrazole ring (in trans to each other) complete the metal coordination sphere. The main bond lengths fall in the same range as those observed for similar pincer $\mathrm{Ni}^{\mathrm{II}}$ halides in the Cambridge Structure Database [mean $d(\mathrm{Ni}-\mathrm{F})$ value $=1.885 \AA{ }^{38,40-42}$ mean $d(\mathrm{Ni}-\mathrm{Cl})=2.206$ $\AA_{;}^{43-46}$ mean $d(\mathrm{Ni}-\mathrm{Br})=2.359 \AA_{;}^{47-51}$ mean $d(\mathrm{Ni}-\mathrm{I})=$ $2.541 \AA \AA^{52-57}$ mean $\left.d\left(\mathrm{Ni}-\mathrm{C}_{\mathrm{ipso}}\right)=1.890 \AA\right]$. Extensive $\mathrm{C}-\mathrm{H} \cdots$ $\mathrm{X}$ intermolecular short contacts involving the methylenic sidearm and the tert-butyl groups on the pincer are present in the solid state. See Table 1 for the crystallographic parameters of 1-4. Table $S 1$ in the Supporting Information compares the main bond lengths and angles among the three crystal structures. An intriguing feature of $\mathbf{1}$ is the presence of one water molecule as the crystallization solvent that engages into multiple hydrogen bonding with three adjacent pincer molecules, creating a trimeric adduct (Figure 2). The high 
Table 1. Crystal Data and Structure Refinement for Complexes 1-4

\begin{tabular}{|c|c|c|c|c|}
\hline & $\mathbf{1} \cdot \mathrm{H}_{2} \mathrm{O}$ & 2 & 3 & 4 \\
\hline CCDC number & 1868355 & 1868356 & 1868357 & 1868358 \\
\hline empirical formula & $\mathrm{C}_{18} \mathrm{H}_{28} \mathrm{FN}_{2} \mathrm{NiOP}$ & $\mathrm{C}_{18} \mathrm{H}_{26} \mathrm{ClN}_{2} \mathrm{NiP}$ & $\mathrm{C}_{18} \mathrm{H}_{26} \mathrm{BrN}_{2} \mathrm{NiP}$ & $\mathrm{C}_{18} \mathrm{H}_{26} \mathrm{IN}_{2} \mathrm{NiP}$ \\
\hline formula weight & 397.10 & 395.54 & 440.00 & 486.99 \\
\hline temperature $[\mathrm{K}]$ & $100(2)$ & $100(2)$ & $150(2)$ & $100(2)$ \\
\hline wavelength $[\AA]$ & 1.5414 & 1.5414 & 0.71069 & 1.5414 \\
\hline crystal system, space group & monoclinic, $P 2_{1} / n$ & triclinic, $P \overline{1}$ & triclinic, $P \overline{1}$ & monoclinic, $P 2_{1} / n$ \\
\hline$a[\AA]$ & $16.001(4)$ & $7.227(5)$ & $7.323(3)$ & $7.503(2)$ \\
\hline$b[\AA]$ & $7.834(18)$ & $11.137(5)$ & $11.064(8)$ & $23.001(6)$ \\
\hline$c[\AA]$ & $16.745(5)$ & $11.461(5)$ & $11.597(9)$ & $11.074(3)$ \\
\hline$\alpha[\mathrm{deg}]$ & 90 & $81.712(5)$ & $82.560(6)$ & 90 \\
\hline$\beta[\operatorname{deg}]$ & $116.551(3)$ & $83.352(5)$ & $83.246(5)$ & $95.603(3)$ \\
\hline$\gamma[\operatorname{deg}]$ & 90 & $85.775(5)$ & $85.250(5)$ & 90 \\
\hline$V\left[\AA^{3}\right]$ & $1877.6(9)$ & $905.2(8)$ & $923.1(11)$ & $1902.0(9)$ \\
\hline$Z, D_{\mathrm{c}}\left[\mathrm{g} \mathrm{cm}^{-3}\right]$ & $4,1.405$ & $2,1.451$ & $2,1.583$ & $4,1.701$ \\
\hline absorption coefficient $\left[\mathrm{mm}^{-1}\right]$ & 2.434 & 3.726 & 3.303 & 14.999 \\
\hline$F(000)$ & 840 & 416 & 452 & 976 \\
\hline crystal size $[\mathrm{mm}]$ & $0.01 \times 0.01 \times 0.02$ & $0.01 \times 0.01 \times 0.07$ & $0.02 \times 0.02 \times 0.05$ & $0.02 \times 0.03 \times 0.05$ \\
\hline $\begin{array}{l}\Theta \text { range for data collection } \\
{[\text { deg }]}\end{array}$ & $5.139-61.891$ & $4.018-72.292$ & $4.319-29.476$ & $4.447-72.183$ \\
\hline limiting indices & $\begin{array}{l}-18 \leq h \leq 18,-5 \leq k \leq 8 \\
-19 \leq l \leq 19\end{array}$ & $\begin{array}{l}-8 \leq h \leq 8,-12 \leq k \leq 13 \\
\quad-11 \leq l \leq 14\end{array}$ & $\begin{array}{l}-8 \leq h \leq 10,-14 \leq k \leq 15 \\
\quad-14 \leq l \leq 15\end{array}$ & $\begin{array}{l}-8 \leq h \leq 7,-27 \leq k \leq 28 \\
-12 \leq l \leq 13\end{array}$ \\
\hline reflections collected/unique & $8595 / 2866$ & $9627 / 3472$ & $8164 / 4188$ & $10457 / 3599$ \\
\hline GOF on $F^{2}$ & 1.029 & 1.040 & 1.177 & 1.108 \\
\hline data/restraints/parameters & $2866 / 0 / 229$ & $3472 / 0 / 214$ & $4188 / 0 / 214$ & $3599 / 0 / 202$ \\
\hline final $R$ indices $[I>2 \sigma(I)]$ & $R_{1}=0.0367, w R_{2}=0.0841$ & $R_{1}=0.0597, \mathrm{w} R_{2}=0.1448$ & $R_{1}=0.0546, \mathrm{w} R_{2}=0.1349$ & $R_{1}=0.0661, \mathrm{w} R_{2}=0.1723$ \\
\hline$R$ indices (all data) & $R_{1}=0.0506, w R_{2}=0.0912$ & $R_{1}=0.0941, \mathrm{w} R_{2}=0.1696$ & $R_{1}=0.0670, \mathrm{w} R_{2}=0.1410$ & $R_{1}=0.0975, \mathrm{w} R_{2}=0.2335$ \\
\hline $\begin{array}{l}\text { largest diff. peak and hole } \\
{\left[\mathrm{e} \AA^{-3}\right]}\end{array}$ & 0.352 and -0.232 & 0.660 and -0.767 & 1.083 and -0.783 & 2.502 and -1.837 \\
\hline
\end{tabular}

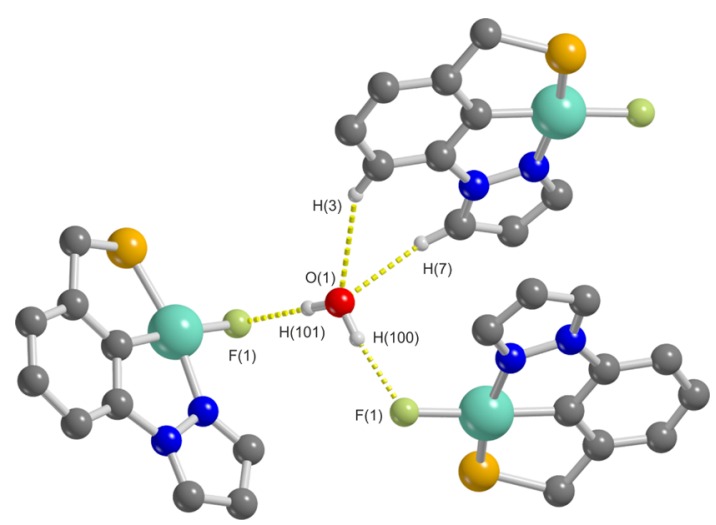

Figure 2. Solid-state structure of the trimeric adduct $\left[(1)_{3} \cdot \mathrm{H}_{2} \mathrm{O}\right]$. Hydrogen atoms on the ligand (except for those involved in the hydrogen bonding) and tert-butyl groups on phosphorus omitted for clarity. Selected bond lengths $[\AA]$ and angles $[\mathrm{deg}]$ for the hydrogen bonding: $d[\mathrm{H}(7) \cdots \mathrm{O}(1)]=2.28 ; d[\mathrm{H}(3) \cdots \mathrm{O}(1)]=2.71 ; d[\mathrm{H}(100) \cdots$ $\mathrm{F}(1)]=d[\mathrm{H}(101) \cdots \mathrm{F}(1)]=1.92 ; \alpha[\mathrm{H}(3)-\mathrm{O}(1)-\mathrm{H}(7)]=62.1 ;$ $\alpha[\mathrm{F}(1)-\mathrm{O}(1)-\mathrm{F}(1) \#]=110.2$.

affinity of transition metal fluorides shown toward water and their tendency to keep hydrogen-bonding interactions with water also in solution was already evidenced in the case of $\left({ }^{t \mathrm{Bu}} \mathrm{PCP}\right) \mathrm{NiF}$ through ${ }^{19} \mathrm{~F}-{ }^{1} \mathrm{H}$ heteronuclear Overhauser spectroscopy (HOESY) NMR experiments. ${ }^{29}$ In $\mathbf{1}$, the ligand acidic protons $\mathrm{H}(3)$ and $\mathrm{H}(7)$ that strongly interact with the oxygen atom from water play a fundamental role in the formation of the trimer. Indeed, the electrostatic potential surface (EPS) of 1 (Figure 3b) highlights an electrophilic region associated with the hydrogen atom of the pyrazole ring a)

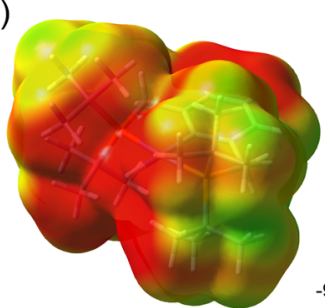

b)

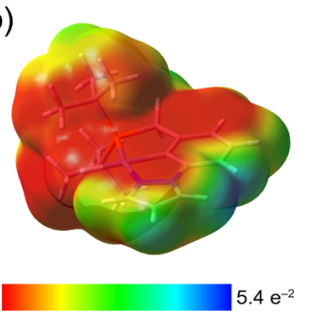

Figure 3. Molecular electrostatic potential, in hartrees, at the 0.001 electrons bohr ${ }^{-3}$ isodensity surface of $\left.{ }^{t B u} \mathrm{PCP}\right) \mathrm{NiF}$ (a) and $\mathbf{1}$ (b). The blue-colored electrophilic region around $\mathrm{H}(7)$ in $\mathbf{1}$ is clearly visible.

lying opposite to the fluoride ligand [H(7)-Figure 2]. This feature is totally absent in the crystal structure of $\left({ }^{t \mathrm{Bu}} \mathrm{PCP}\right) \mathrm{NiF}$ (Figure 3a). ${ }^{38}$ The hydrogen bond interaction between 1 and $\mathrm{H}_{2} \mathrm{O}$ seems to survive also in solution, and it can be at the origin of the positive $\Delta S^{\circ}$ value measured for the formation of the halogen-bonded adduct 1 ‥IPFB (vide infra, Section 2.2).

2.2. Reaction of 1 and ( $\left.{ }^{\mathrm{tB}} \mathrm{PCP}\right) \mathrm{NiF}$ with IPFB: Halogen Bonding. NMR spectroscopy has been actively used in recent years to probe the presence and strength of the halogen bond both in solution ${ }^{58,59}$ and in solid state. ${ }^{60-63}$ NMR spectroscopy was used to probe the ability of the fluorides, $\left({ }^{\mathrm{BB}} \mathrm{PCP}\right) \mathrm{NiF}$ and $\mathbf{1}$, to act as halogen-bond acceptors. We showed that both act as a Lewis base in the formation of halogen bonds with the halogen-bond donor, IPFB $\left(\mathrm{C}_{6} \mathrm{~F}_{5} \mathrm{I}\right.$, Scheme 2). IPFB is a very efficient halogen-bond donor because the presence of fluorine constituents greatly increases the electrophilicity of the iodine atom through the formation of a $\sigma$-hole. ${ }^{64}$ 
Scheme 2. Halogen Bonding between $\left({ }^{\mathrm{tBu}} \mathrm{PCE}\right) \mathrm{NiF}(\mathrm{E}=\mathrm{P}$, N) and IPFB

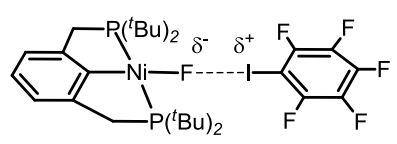

( $\left.{ }^{\text {Bu }} \mathrm{PCP}\right) \mathrm{NiF}$

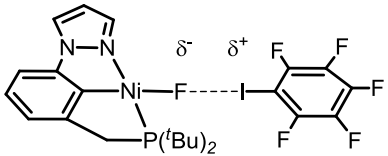

( $\left.{ }^{\text {Bu }} \mathrm{PCN}\right) \mathrm{NiF}(\mathbf{1})$
The formation of adducts was monitored by VT multinuclear $\left({ }^{1} \mathrm{H}\right.$ and $\left.{ }^{19} \mathrm{~F}\right)$ NMR spectroscopy. The ${ }^{19} \mathrm{~F}$ NMR chemical shift of the metal fluoride was used to evaluate the thermodynamics of the interactions. ${ }^{19} \mathrm{~F}$ represents a reliable spectroscopic probe as it is very sensitive to the fluorine chemical environment, and the signal overlapping is very rare because of the very broad chemical shift dispersion. The effective formation of a halogen-bonded adduct in solution was ascertained by evaluating the shift of the ${ }^{19} \mathrm{~F}$ resonance upon halogen bond formation. Titration experiments were carried out in deuterated tetrahydrofuran (THF)- $d_{8}$ at variable temperature. The room temperature ${ }^{19} \mathrm{~F}$ NMR fluoride signal of the two complexes falls at $-371.7\left[\left({ }^{\mathrm{B} u} \mathrm{PCP}\right) \mathrm{NiF}\right]$ and -347.2 (1) ppm (Figure 4a,c). The ${ }^{19} \mathrm{~F}$ chemical shift of the fluoride resonance was monitored while varying the fluoride/ IPFB molar ratio. Upon addition of an excess (20 times) of the halogen-bond donor at room temperature, the fluoride resonances exhibited an extensive high-frequency shift to $\sim-362\left(\Delta \delta_{293}=10 \mathrm{ppm}\right)$ and $\sim-327 \mathrm{ppm}\left(\Delta \delta_{293}=20 \mathrm{ppm}\right)$ for $\left.{ }^{t \mathrm{Bu}} \mathrm{PCP}\right) \mathrm{NiF}$ and $\mathbf{1}$, respectively (Figure $4 \mathrm{~b}, \mathrm{~d}$ ).

At $233 \mathrm{~K}$, the fluoride resonances shift from $\sim-369$ to $\sim-354 \mathrm{ppm}\left[\left({ }^{\mathrm{B} u} \mathrm{PCP}\right) \mathrm{NiF}\right]\left(\Delta \delta_{233}=15 \mathrm{ppm}\right)$ and from $\sim-341$ to $\sim-320 \mathrm{ppm}(1)\left(\Delta \delta_{233}=21 \mathrm{ppm}\right)$ upon addition of IPFB (Figure S1 in the Supporting Information). IPFB (present in excess) shows only small negligible changes in its ${ }^{19} \mathrm{~F}$ chemical shifts.

The 1:1 stoichiometry of the adducts was ascertained from the Job plots. The change in the chemical shift of the ${ }^{19} \mathrm{~F}$ resonance $(\Delta \delta)$ was monitored as a function of the IPFB molar fraction $(\chi)$ while keeping the sum of the concentrations [metal complex $]+[\mathrm{IPFB}]$ constant and equal to $0.01 \mathrm{~mol} \cdot \mathrm{L}^{-1}$. The graph of $\chi \Delta \delta$ versus $\chi$ showed a maximum at $\chi=0.5$ as expected for a 1:1 complex (Figure 5). Interestingly, the broad appearance of the plot of $\mathbf{1}$ (Figure $5 \mathrm{~b}$ ) can be attributed to a displacement rather than an association reaction, ${ }^{65}$ suggesting a possible role of water in the adduct formation.
Binding constants, enthalpies, and entropies of these interactions were evaluated through ${ }^{19} \mathrm{~F}$ NMR titration experiments. Figure 6 shows the titration data for the experiments with both fluorides. For all curves, a significant influence of the temperature on the chemical shifts is observed because of the complexes interaction with IPFB. In ( $\left.{ }^{t B u} \mathrm{PCP}\right)$ $\mathrm{NiF}$, this effect is relevant for high IPFB concentrations, whereas only small chemical shift differences are found for low concentrations. For 1, the effect seems to be concentration independent. The obtained titration curves were fitted using the simple model of eq 1 . This allowed to extract the equilibrium constant $\left(K_{\mathrm{eq}}\right)$ for formation of the adduct and the difference between the ${ }^{19} \mathrm{~F}$ chemical shift of the free metal fluoride and of the pure adduct $\left(\Delta \delta^{\mathrm{fit}}\right)$.

$$
[\mathrm{Ni}]-\mathrm{F}+\mathrm{IPFB} \leftrightarrow[\mathrm{Ni}]-\mathrm{F} \cdots \mathrm{IPFB}
$$

Thermodynamic data (equilibrium constant, standard reaction enthalpy, and entropy) were obtained from titration curves acquired at various temperatures and from the van't Hoff plot ( $\ln K$ vs $T^{-1}$ ). Analysis of the titration data gave excellent fits in all cases as well as the resulting van't Hoff plots $\left(R^{2}=0.99\right)$ (Figure 7$)$. The thermodynamic values for both fluorides are reported in Table 2.

Binding enthalpy values $\left[-7.3\right.$ and $-4.1 \mathrm{~kJ} \cdot \mathrm{mol}^{-1}$ for $\left({ }^{t \mathrm{Bu}} \mathrm{PCP}\right) \mathrm{NiF}$ and $\mathbf{1}$, respectively] are smaller than those reported in the literature for other metal fluoride complexes (falling in the range between -16 and $-26 \mathrm{~kJ} \cdot \mathrm{mol}^{-1}$ ), thereby indicating the formation of weaker interactions. ${ }^{30,31}$ However, comparison of $\mathbf{1}$ with the other samples might be compromised by a possible association with water also in solution.

Interestingly, complex 1 shows a positive $\Delta S^{\circ}$. This suggests the formation of aggregates, likely dimers or adducts with water molecules, of $\mathbf{1}$ in solution. This hypothesis is supported by the crystallographic evidence [vide supra, Section 2.1] and by the EPS calculations. Indeed, in the solid state, 1 forms trimers kept together by a triply bridging water molecule through $\mathrm{O}-\mathrm{H} \cdots \mathrm{F}$ and $\mathrm{C}-\mathrm{H} \cdots \mathrm{O}$ hydrogen bonding (Figure 2). However, diffusion ordered spectroscopy experiments (see Figure S2 in the Supporting Information) ruled out the existence of such a trimer in solution; thus, a simple water adduct $\left(\mathbf{1} \cdot \mathrm{H}_{2} \mathrm{O}\right)$ kept together by a strong hydrogen bond interaction with water is much more likely to be the solution form, as suggested by the Job plot shape (see above) and by the EPS. Indeed, the electrophilic regions evidenced in the EPS of $\mathbf{1}$ (Figure $3 \mathrm{~b}$ ) indicate that $\mathrm{H}(7)$ could act as a hydrogen-
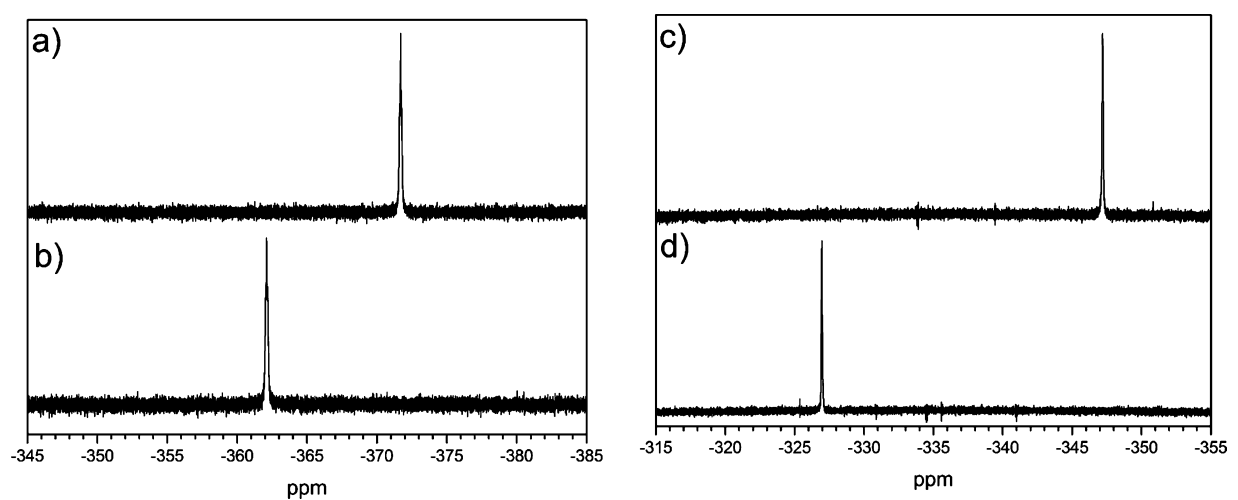

Figure 4. Plots of the fluoride region of the ${ }^{19} \mathrm{~F}$ NMR spectra of $\left({ }^{\mathrm{tBu}} \mathrm{PCP}\right) \mathrm{NiF}$ (left) and $\mathbf{1}$ (right) at $293 \mathrm{~K}$ with increasing equivalents of IPFB in THF- $d_{8}$. (a) Pure $\left({ }^{t B u} \mathrm{PCP}\right) \mathrm{NiF}$; (b) $\left.{ }^{\mathrm{tBu}} \mathrm{PCP}\right) \mathrm{NiF}$ with an excess of IPFB; (c) pure 1 ; (d) 1 with an excess of IPFB. 

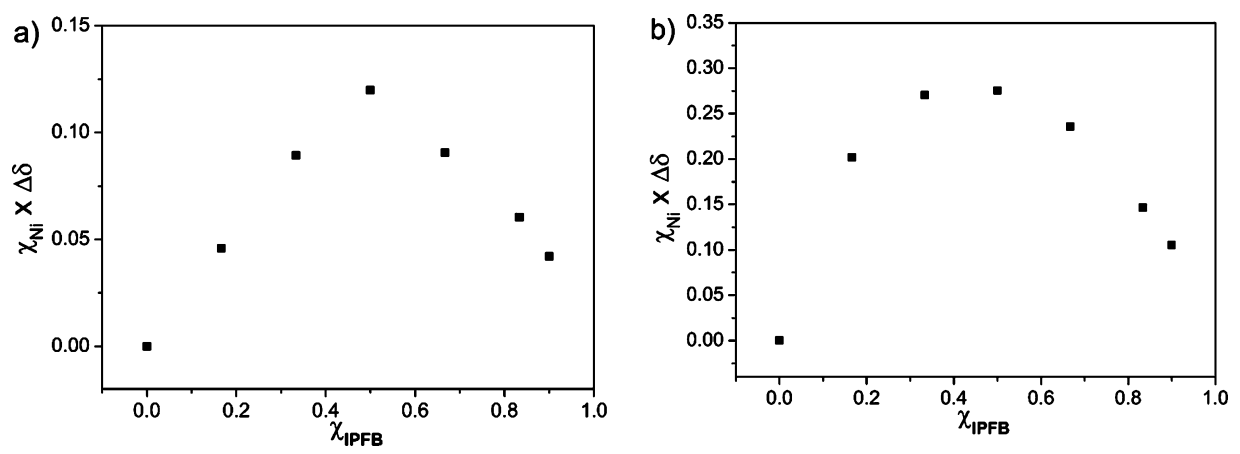

Figure 5. Job plot for IPFB and $\left({ }^{t B u} \mathrm{PCP}\right) \mathrm{NiF}(\mathrm{a})$ or $\mathbf{1}(\mathrm{b})$; total concentration $=0.01 \mathrm{M}$.
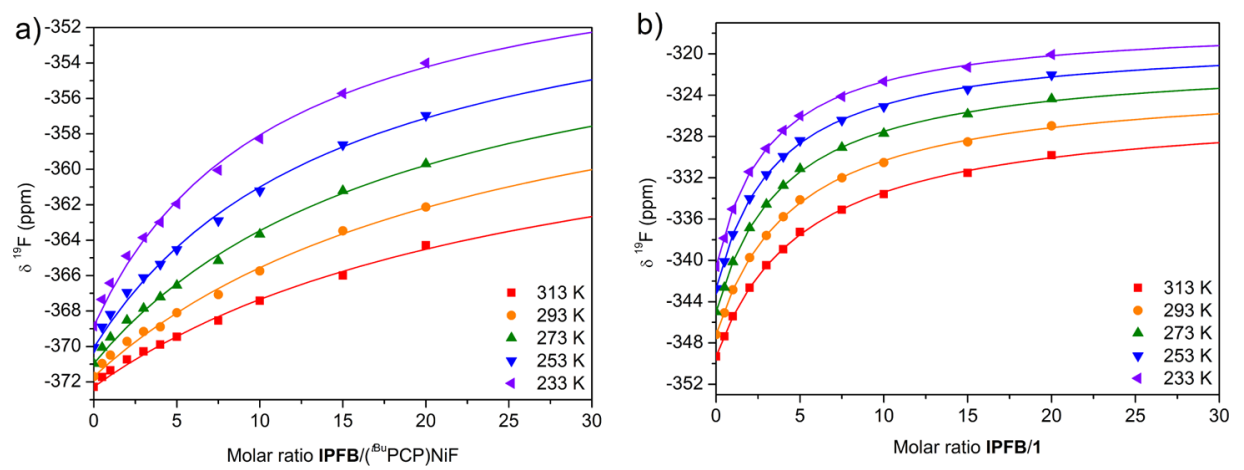

Figure 6. Fit of the titration curves at different temperatures showing observed values for $\delta^{19} \mathrm{~F}$ vs (complex: IPFB) molar ratio for $\left({ }^{t B u} \mathrm{PCP}\right) \mathrm{NiF}(\mathrm{a})$ or $1(b)$.
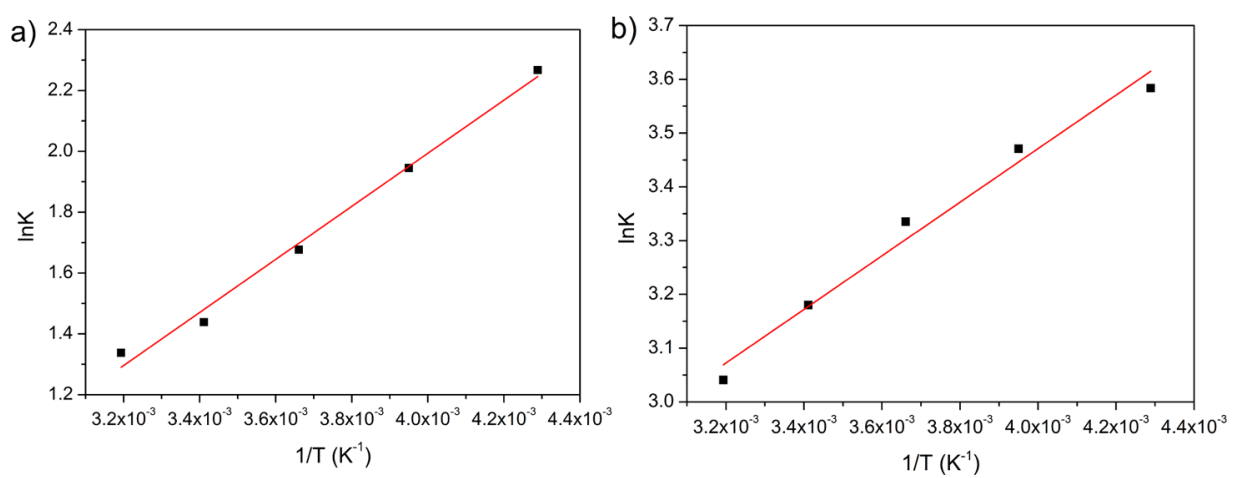

Figure 7. van't Hoff plot for halogen bonding of IPFB and complex $\left({ }^{t \mathrm{Bu}} \mathrm{PCP}\right) \mathrm{NiF}(\mathrm{a})$ or $\mathbf{1}$ (b). Data were fitted with the following equations: $y=$ $-1.50+872.60 x, R^{2}=0.99(\mathrm{a}) ; y=1.48+498.38 x, R^{2}=0.98(\mathrm{~b})$.

Table 2. Thermodynamic Data $\left(\Delta H^{\circ}\right.$ in $\mathrm{kJ} \cdot \mathrm{mol}^{-1}$ and $\Delta S^{\circ}$ in $\left.\mathrm{J} \cdot \mathrm{mol}^{-1} \cdot \mathrm{K}^{-1}\right)$ for Halogen Bonding of $\left({ }^{t \mathrm{Bu}} \mathrm{PCP}\right) \mathrm{NiF}$ and 1 with IPFB in THF- $d_{8}{ }^{a}$

\begin{tabular}{ccrccc} 
compound & $\Delta H^{\circ}$ & \multicolumn{1}{c}{$\Delta S^{\circ}$} & $K_{293}$ & $K_{233}{ }^{b}$ & $\Delta \delta_{293}^{\text {fit }}{ }^{c}$ \\
${ }^{\left({ }^{\mathrm{BBu}} \mathrm{PCP}\right) \mathrm{NiF}}$ & $-7.3 \pm 0.8$ & $-12 \pm 3$ & 4 & 10 & 21 \\
1 & $-4.1 \pm 0.7$ & $12 \pm 3$ & 24 & 36 & 25
\end{tabular}

${ }^{a}$ Errors at $95 \%$ confidence level. ${ }^{b}$ Extrapolated to $233 \mathrm{~K} .{ }^{c} \Delta \delta_{293}^{\mathrm{fit}}=$ chemical shift difference between free metal fluoride and metal fluoride $\cdots$ IPFB adduct, calculated from the curve fitting.

bond donor for oxygen lone pairs of water molecules. Unfortunately, ${ }^{1} \mathrm{H}-{ }^{19} \mathrm{~F}$ HOESY experiments recorded both at room temperature and at $253 \mathrm{~K}$ did not provide the necessary evidence to support this assumption, probably due to the very short ${ }^{19} \mathrm{~F} T_{1}$ values related to the very efficient chemical shift anisotropy (CSA) contribution to the ${ }^{19} \mathrm{~F}$ spin lattice relaxation time. Indeed, a large $\operatorname{CSA}(\Omega=663 \pm 20$ ppm) previously found for $\left({ }^{t B u} \mathrm{PCP}\right) \mathrm{NiF}$ from the spinning side band analysis ${ }^{29}$ explains why the heteronuclear dipolar mechanism is negligible compared with the much more efficient CSA mechanism.

2.3. Electrochemical Studies. As a further characterization study, all synthesized complexes were characterized via $\mathrm{CV}$ and in situ EPR spectro-electrochemistry. CV curves were recorded at an ambient temperature $(T=293 \mathrm{~K})$ using a glassy carbon (GC) as the working electrode at the constant potential scan rate of $50 \mathrm{mV} \cdot \mathrm{s}^{-1}$. Figure 8 outlines the voltammetric profiles of all $\mathrm{Ni}$ halides in the cathodic and anodic regions, whereas Table 3 lists the observed peak potentials. At negative potentials, all complexes show an irreversible reduction peak $\left(\mathrm{C}_{1}\right)$ ascribed to the $\mathrm{Ni}^{\mathrm{II}} \rightarrow \mathrm{Ni}^{0}$ conversion whose value $[E$ (V)] changes as a function of the halogen type. The higher the halide electronegativity, the higher the overpotential value at which reduction occurs. The appearance of minor reoxidation 


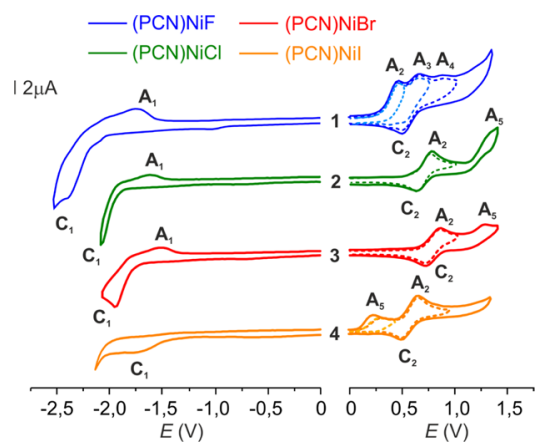

Figure 8. CV curves (cathodic-left and anodic-right) of the investigated complexes $\mathbf{1}$ (blue), $\mathbf{2}$ (green), $\mathbf{3}$ (red), and $\mathbf{4}$ (yellow) recorded in DMF $\left(C=5 \times 10^{-3} \mathrm{M}\right)$ in the presence of $\left(\mathrm{Bu}_{4} \mathrm{~N}\right) \mathrm{BF}_{4}$ $\left(10^{-1} \mathrm{M}\right) . \mathrm{CV}$ curves were recorded without infrared compensation at the first scan at a constant potential scan rate $50 \mathrm{mV} \cdot \mathrm{s}^{-1}$ (GC working electrode, $T=293 \mathrm{~K})$. Peak potentials are referred to $\mathrm{Ag} / \mathrm{AgNO}_{3}$, $0.01 \mathrm{M}$ in the $\mathrm{CH}_{3} \mathrm{CN}$ reference electrode. The dashed lines represent the $\mathrm{CV}$ curves recorded at the scanning of the anodic potential of the working electrode up to the peaks $A_{2}, A_{3}$, and $A_{5}$.

Table 3. Peak Potentials (E, V) on the CV Curves of the PCN Pincer Complexes 1-4

\begin{tabular}{|c|c|c|c|c|}
\hline \multirow{2}{*}{$\frac{\text { complex }}{\left({ }^{t \mathrm{Bu}} \mathrm{PCN}\right) \mathrm{NiF}(\mathbf{1})}$} & \multicolumn{2}{|c|}{ reduction } & \multicolumn{2}{|c|}{ oxidation } \\
\hline & $\mathrm{C}_{1}$ & -2.39 & $\mathrm{~A}_{2}$ & 0.44 \\
\hline & $A_{1}$ & -1.72 & $\mathrm{~A}_{3}$ & 0.65 \\
\hline & & & $\mathrm{A}_{4}$ & 0.88 \\
\hline & & & $\mathrm{C}_{2}$ & 0.52 \\
\hline \multirow[t]{3}{*}{$\left({ }^{t \mathrm{Bu}} \mathrm{PCN}\right) \mathrm{NiCl}(2)$} & $\mathrm{C}_{1}$ & -2.13 & $\mathrm{~A}_{2}$ & 0.79 \\
\hline & $\mathrm{A}_{1}$ & -1.64 & $\mathrm{~A}_{5}$ & 1.32 \\
\hline & & & $\mathrm{C}_{2}$ & 0.63 \\
\hline \multirow[t]{3}{*}{$\left({ }^{t \mathrm{Bu}} \mathrm{PCN}\right) \mathrm{NiBr}(3)$} & $\mathrm{C}_{1}$ & -1.98 & $\mathrm{~A}_{2}$ & 0.83 \\
\hline & $\mathrm{A}_{1}$ & -1.56 & $\mathrm{~A}_{5}$ & 1.27 \\
\hline & & & $\mathrm{C}_{2}$ & 0.72 \\
\hline \multirow[t]{3}{*}{$\left({ }^{t B u} \mathrm{PCN}\right) \mathrm{NiI}(4)$} & $\mathrm{C}_{1}$ & -1.70 & $\mathrm{~A}_{5}$ & 0.29 \\
\hline & & & $\mathrm{A}_{2}$ & 0.64 \\
\hline & & & $\mathrm{C}_{2}$ & 0.45 \\
\hline
\end{tabular}

${ }^{a} \mathrm{CV}$ curves were registered without infrared compensation. The mentioned potentials are referred to $\mathrm{Ag} / \mathrm{AgNO}_{3}, 0.01 \mathrm{M}$ in $\mathrm{CH}_{3} \mathrm{CN}$ $\left[E^{\circ}\left(\mathrm{Fc} / \mathrm{Fc}^{+}\right)=+0.20 \mathrm{~V}\right]$.

peaks $\left(\mathrm{A}_{1}\right)$ for $1-3$ in the -1.56 to $-1.72 \mathrm{~V}$ range is reasonably ascribed to the adsorption of traces of $\mathrm{Ni}(0)$ species at the surface of the working electrode. On the other hand, the complexes display different shapes of the anodic part of their $\mathrm{CV}$ curves. Thus, for $\mathbf{2}$ and 3, quasi-reversible oxidation peaks $\left(A_{2}-A_{4}\right)$ are observed (Figure 9), which correspond to the formation of stable nickel(III) derivatives in the electrochemical process. In the case of 4 , a new irreversible oxidation peak $A_{5}$ at less positive potentials is observed. This peak corresponds to the oxidation of free iodine anions. In fact, the addition of an increasing amount of tetrabutylammonium iodide to the working solution translates into an increase of $A_{5}$ and $A_{2}$ currents (see Figure $S 3$ in the Supporting Information). The increase of both $A_{5}$ and $A_{2}$ is due to a two-step oxidation of the free iodide anion that goes through a putative $\mathrm{I}_{3}{ }^{-}$ intermediate. $^{66,67}$ As expected, the corresponding oxidation process of free chloride and bromide anions takes place at higher potentials, whereas the oxidation of fluoride is not observed because it falls out of the selected potential range. For complex 1 , three oxidation peaks $A_{2}, A_{3}$, and $A_{4}$ are observed in solution. The first one $\left(A_{2}\right)$ is irreversible, and it is ascribed to

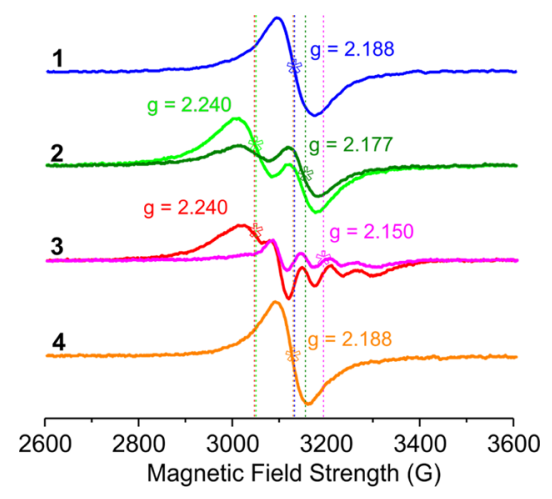

Figure 9. EPR spectra of 1-4 obtained in the EPR spectroelectrochemical cell using DMF as the solvent $\left[5 \times 10^{-3} \mathrm{M}\right]$ in the presence of $\left(\mathrm{NBu}_{4}\right) \mathrm{BF}_{4}[0.1 \mathrm{M}]$ recorded during the electrochemical oxidation process $(1.5 \mathrm{~V}$ for $1,0.8 \mathrm{~V}$ for $2,0.8 \mathrm{~V}$ for 3 , and $0.5 \mathrm{~V}$ for 4 ) at $300 \mathrm{~K}$. The two different curves reported for complexes 2 and 3 refer to the square planar and tetrahedral four-coordinated $\mathrm{Ni}^{\mathrm{III}}$ complexes bearing coordinated halogen, as sketched in Scheme 3.

the formation of the $\mathrm{Ni}^{\mathrm{III}}$ complex 5 (Scheme 4-vide infra), whereas $A_{3}$ and $A_{4}$ are reversible, and they may be ascribed to a sequential $\left[\mathrm{Ni}^{\mathrm{III}} \cdot \ldots \mathrm{Ni}^{\mathrm{III}}\right] \rightarrow\left[\mathrm{Ni}^{\mathrm{IV}} \cdots \mathrm{Ni}^{\mathrm{III}}\right] \rightarrow\left[\mathrm{Ni}^{\mathrm{iV}} \cdot \ldots \mathrm{Ni}^{\mathrm{IV}}\right]$ oxidation of the two $\mathrm{Ni}^{\mathrm{III}}$ metal ions within the dimeric species 7 formed in the electrochemical process after the first oxidation of $\mathbf{1}$ at $\mathrm{A}_{2}$ (Scheme 4$) . \mathrm{Ni}^{\mathrm{IV}}$ stable organometallic complexes containing pincer ligands are known; ${ }^{68,69}$ they have been obtained through electrochemical methods starting from their $\mathrm{Ni}^{\mathrm{II}}$ analogues. Their proven stability may be at the origin of the reversibility of the $\mathrm{A}_{3}$ and $\mathrm{A}_{4}$ oxidation peaks.

To get additional insights about the nature of the species formed in the electrochemical process, the in situ EPR spectroelectrochemical study was performed on each compound. The comparison of experimentally obtained and simulated EPR spectra is reported in the Supporting Information (Figures S4S7 and Table S2). The data reveal that under reducing conditions, a $2 \mathrm{e}^{-}$process takes place directly with the formation of diamagnetic $\mathrm{Ni}(0)$ complexes, as no radical species has been detected through EPR analysis. Under oxidative conditions, we observed interesting results with complexes 2 and 3 . At the $\mathrm{A}_{2}$ potential values, $\mathrm{Ni}$ (III) species bearing coordinated halogen in solution are formed ( $g$-factor is 2.177 for 2 and 2.150 for 3, see Figure 9). The presence of the halogen in the metal coordination sphere is clearly visible in 3 . Indeed, its EPR spectrum shows a hyperfine interaction (HFI) and signal coupling coming from the ${ }^{79} \mathrm{Br}$ and ${ }^{81} \mathrm{Br}$ isotopes (I $=3 / 2$ ) that are responsible for the generation of four lines with a hyperfine splitting of $58 \mathrm{G}$. No hyperfine coupling was observed for 2 because of the very small coupling constant of ${ }^{35} \mathrm{Cl}$ and ${ }^{37} \mathrm{Cl}$ isotopes (parallel $=29 \mathrm{G}$, perpendicular $=8 \pm 2$ $\mathrm{G}) .^{70}$

In line with several literature precedents, it can also be claimed that $\mathrm{Ni}^{\mathrm{II}} \rightarrow \mathrm{Ni}^{\mathrm{III}}$ oxidation causes a coordination geometry modification from square planar to distorted tetrahedral (Scheme 3$).^{71}$ The latter is additionally supported by the relatively high experimental $\Delta V\left(\mathrm{~A}_{2}-\mathrm{C}_{2}\right)$ values $(160$ and $110 \mathrm{mV}$ for 2 and 3, respectively) together with a larger $g$ factor $(g=2.240) . \Delta V$ is too high for a simple and reversible one-electron transfer process, but these data match well with a coordination geometry change and with a halide ligand moving from an equatorial to axial position. Furthermore, literature precedents show that $d^{7}-\mathrm{Ni}$ (III) complexes are generally in the 
Scheme 3. Electrochemical Oxidation of Complexes 2 and 3 and Related Coordination Geometry Change from Square Planar to Tetrahedral

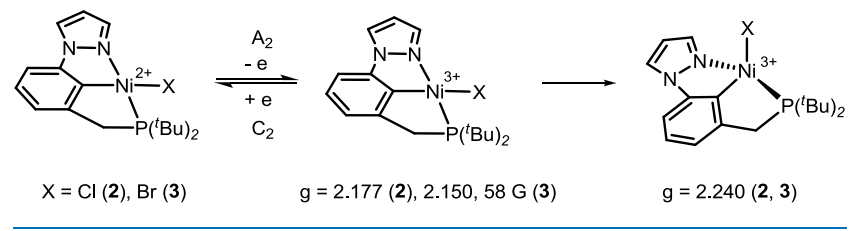

form of low-spin species $(S=1 / 2)$ with a strong preference for the tetrahedral coordination geometry. ${ }^{72}$ The same $g$-value of $\mathrm{Ni}(\mathrm{III})$ complexes derived from $\mathbf{2}$ or $\mathbf{3}$ comes from a weaker HFI of the nuclear spin of the halogen atom in the axial position. It is worth mentioning that this isomerization proceeds even after the electric current switch off (Figure S8).

A comparison of the in situ EPR spectro-electrochemical studies carried out on complexes $\mathbf{1}$ and $\mathbf{4}$ shows that during the oxidation process, both compounds converge to the same radical species $9(g=2.188$, Scheme 4$)$, although potentials required for its generation are different. In the case of $\left({ }^{t \mathrm{Bu}} \mathrm{PCN}\right) \mathrm{NiI}$, the formation of 9 already takes place at $E=0.5$ $\mathrm{V}$, and it comes from the oxidation of the halogen-free form 6 . As for $\left.{ }^{t \mathrm{Bu}} \mathrm{PCN}\right) \mathrm{NiF}, 9$ is obtained at a more oxidizing potential $(E=1.5 \mathrm{~V})$ with no radical species observed at the anodic peaks $A_{2}, A_{3}$, and $A_{4}$. In this case, it can be supposed that the formation of 9 proceeds with time through the simultaneous occurrence of faradic and chemical processes. After initial fluoride oxidation, dimerization of the resulting $\left[\left({ }^{t \mathrm{Bu}} \mathrm{PCN}\right) \mathrm{Ni}^{\mathrm{III}} \mathrm{F}\right]^{\bullet /+}$ radical-cation 5 leads to the intermediate 7 bearing $\mathrm{Ni}^{\mathrm{III}}(\mu-\mathrm{F}){ }_{2} \mathrm{Ni}^{\mathrm{III}}$ bridging fragments. After a heterolytic bond cleavage occurring in 7 , the monomeric $\left({ }^{t \mathrm{Bu}} \mathrm{PCN}\right) \mathrm{Ni}^{\mathrm{III}} \mathrm{F}_{2}$ species 8 and the halogen-free $\mathrm{Ni}^{\mathrm{iII}}$ complex 9 are then obtained as final reaction products (Scheme 4 ). This behavior mirrors that found in other organometallic Ni halides bearing assorted aromatic $\mathrm{N}$-containing ligands (pyridine, ${ }^{73}$ benzo $[h]$ quinoline $\left.{ }^{74}\right)$. The overall mechanism of the electrooxidation process observed for $\mathbf{1}$ and $\mathbf{4}$ is sketched in Scheme 4. Notably, the EPR spectrum for the dimeric intermediate 7 could not be observed because of its fast evolution to the monomeric species 8 and $\mathbf{9}$ and because of the presence of antiferromagnetic coupling between the two paramagnetic $\mathrm{d}^{7}$
$\mathrm{Ni}(\mathrm{III})$ cores $(S=1 / 2)$ magnetically coupled to each other via a direct $\mathrm{d}-\mathrm{d}$ orbital overlap. ${ }^{75}$ A similar diamagnetic behavior was also observed for the related binuclear $\left[\mathrm{Ni}^{\mathrm{III}}\{\mu-\mathrm{O}\}\right]_{2}$ complexes formed by hydrotris(pyrazolyl)borate ligand $\left(\mathrm{Tp}^{-}\right)^{76}$ and for some bromo-derivatives with a $\left[\mathrm{Ni}^{\mathrm{III}}(\mu\right.$ $\left.\mathrm{Br}) \mathrm{Ni}^{\mathrm{III}}\right]$ binuclear core, ${ }^{77}$ where antiferromagnetically coupled low-spin $\mathrm{Ni}^{\mathrm{III}}$ centers have been invoked to justify their EPRsilent nature. The absence of an EPR signal related to the paramagnetic complex $\left({ }^{t \mathrm{Bu}} \mathrm{PCN}\right) \mathrm{NiF}_{2}(\mathbf{8}$, Scheme 4$)$ is justified by invoking its very low concentration in solution. In fact, previous literature studies on related $\mathrm{Ni}^{\mathrm{iII}} \mathrm{F}_{2}$ complexes showed that they rapidly undergo $\mathrm{F}^{-}$loss from the metal coordination sphere. ${ }^{40,78}$ In the case of the paramagnetic intermediate $\mathbf{8}$, a fast regeneration of the square planar $\mathrm{Ni}^{\mathrm{III}} \mathrm{F}$ radical cation (5) is thought to occur, "quenching" the paramagnetic signal through dimerization to the EPR-silent 7.

\section{CONCLUSIONS}

The unsymmetrical ( $\mathrm{PCN})$ pincer halides $\left({ }^{t \mathrm{Bu}} \mathrm{PCN}\right) \mathrm{NiX}$ have been prepared and thoroughly characterized, both in solution and in the solid state. The high nucleophilicity of the fluoride ligand in $\left({ }^{t \mathrm{Bu}} \mathrm{PCN}\right) \mathrm{NiF}$ leads to halogen bonding with the electrophilic iodine atom in IPFB. The thermodynamic data on halogen bonding are inferred from the titration of ( $\left.{ }^{t \mathrm{Bu}} \mathrm{PCN}\right)$ $\mathrm{NiF}$ with IPFB at different temperatures. The halogen-bonding capability is weaker than that of the symmetrical analogue $\left({ }^{t \mathrm{Bu}} \mathrm{PCP}\right) \mathrm{NiF}$, and it is featured by a positive $\Delta S^{\circ}$ value because of higher degree of aggregation in solution (presence of adducts with water molecules). The different behavior of $\left({ }^{t} \mathrm{Pu} \mathrm{PCN}\right) \mathrm{NiF}$ with respect to the other halides of the family is also observed during its electrochemical oxidation: three distinct anodic peaks are recorded on the CV curve and no halogen loss takes place after oxidation, at odds with what is observed for the other scrutinized complexes. The pyrazole sidearm in the ligand backbone with its acidic protons switches on hydrogen-bonding interactions with other neighboring molecules. These weak interactions [that are not present in the bis(phosphine) $\left({ }^{t \mathrm{Bu}} \mathrm{PCP}\right) \mathrm{NiX}$ analogues] are at the origin of the observed phenomena.

Scheme 4. Proposed Pathways for the Electrochemical Oxidation of Complexes 1 and $4^{a}$

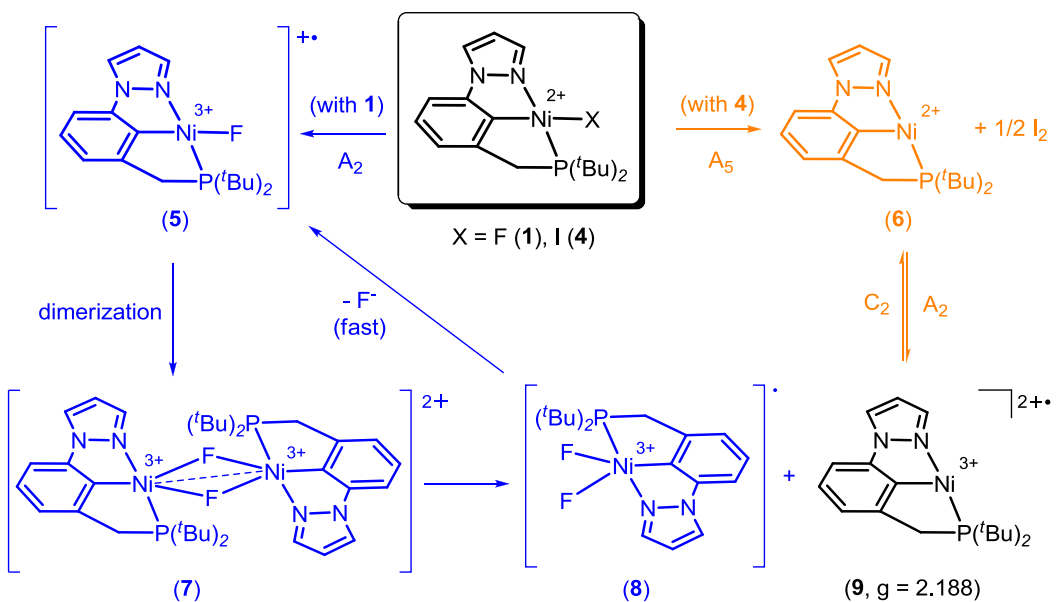

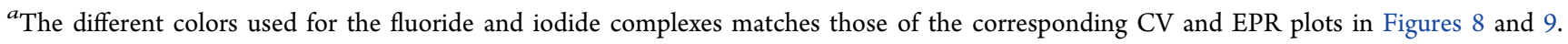




\section{EXPERIMENTAL SECTION}

4.1. Materials and Methods. All reactions were performed using standard Schlenk procedures under a dry nitrogen atmosphere. The ${ }^{t \mathrm{Bu}} \mathrm{PCN}(\mathrm{H})$ ligand ${ }^{37}$ and $\left({ }^{t \mathrm{Bu}} \mathrm{PCP}\right)$ $\mathrm{NiF}\left[{ }^{t \mathrm{Bu}} \mathrm{PCP}=2,6-\mathrm{C}_{6} \mathrm{H}_{3}\left(\mathrm{CH}_{2} \mathrm{P}^{t} \mathrm{Bu}_{2}\right)_{2}\right]^{38}$ were prepared according to the published procedures. Commercial reagents [anhydrous $\mathrm{NiX}_{2}(\mathrm{X}=\mathrm{Cl}, \mathrm{Br}$, or $\mathrm{I}), \mathrm{TlF}, \mathrm{NEt}_{3}$, and $\mathrm{C}_{6} \mathrm{~F}_{5} \mathrm{I}$ ] were purchased from Aldrich and used as received, without further purification. Methanol and toluene were purified by standard distillation techniques. Dimethylformamide (DMF) was dried with calcium hydride and purified by distillation. The electrolyte, $\left(\mathrm{NBu}_{4}\right) \mathrm{BF}_{4}$, was dried by melting in vacuum and stored under nitrogen. $\mathrm{CD}_{2} \mathrm{Cl}_{2}$ and THF- $d_{8}$ (Aldrich) were stored over $4 \AA$ molecular sieves and degassed by three freezepump-thaw cycles before use. NMR spectra were recorded on Bruker AVANCE 400 and 300 spectrometers or on a JEOL ECP 400 FT-NMR spectrometer. ${ }^{1} \mathrm{H}$ and ${ }^{13} \mathrm{C}\left\{{ }^{1} \mathrm{H}\right\}$ chemical shifts are reported in parts per million (ppm) downfield of tetramethylsilane and were calibrated against the residual resonance of the deuterated solvent, whereas ${ }^{31} \mathrm{P}\left\{{ }^{1} \mathrm{H}\right\}$ chemical shifts were referenced to $85 \% \mathrm{H}_{3} \mathrm{PO}_{4}$ with downfield shift taken as positive. ${ }^{19} \mathrm{~F}$ chemical shifts were referenced to external $\mathrm{CFCl}_{3}$ at $\delta=0$. The temperature of the probe was calibrated according to published procedures. ${ }^{79}$ Fourier transform infrared (FTIR) spectra in the solid state $(\mathrm{KBr}$ pellets) were recorded on a PerkinElmer Spectrum BX series FTIR spectrometer in the $4000-400 \mathrm{~cm}^{-1}$ range with a $2 \mathrm{~cm}^{-1}$ resolution. Elemental analyses were carried out by means of a Carlo Erba model 1106 elemental analyzer with an accepted tolerance of 0.4 units on $\mathrm{C}, \mathrm{H}$, and $\mathrm{N}$.

4.1.1. Synthesis of ( $\left.{ }^{B u} P C N\right) N i F(1)$.

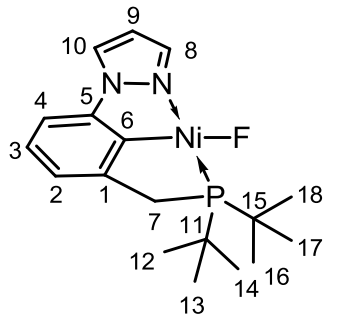

TlF (0.423 g, $1.9 \mathrm{mmol})$ was added to a solution of $\left({ }^{t \mathrm{Bu}} \mathrm{PCN}\right) \mathrm{NiCl}(2,0.150 \mathrm{~g}, 0.38 \mathrm{mmol})$ in dry and degassed $\mathrm{MeOH}(100 \mathrm{~mL})$. The reaction mixture was then stirred under reflux for $24 \mathrm{~h}$. After cooling, the supernatant was filtered off, and the solvent was removed under vacuum. The yellow residue was then extracted with toluene $(3 \times 20 \mathrm{~mL})$, and the solvent collected was concentrated in vacuo to afford the product as a yellow solid ( $0.122 \mathrm{~g}$, yield $85 \%)$. NMR spectra in $\mathrm{CD}_{2} \mathrm{Cl}_{2}$ are reported in the Supporting Information (Figures S9-S11). Crystals suitable for X-ray diffraction in the form of yellow needles were obtained from slow evaporation of a THF solution of the complex at room temperature.

${ }^{1} \mathrm{H}$ NMR $\left(300 \mathrm{MHz}, \mathrm{CD}_{2} \mathrm{Cl}_{2}, 293 \mathrm{~K}\right): \delta 1.49\left(\mathrm{~d},{ }^{3} \mathrm{~J}_{\mathrm{PH}}=13.4\right.$ $\left.\mathrm{Hz}, 18 \mathrm{H}, \mathrm{P}-\mathrm{C}\left(\mathrm{CH}_{3}\right)_{3}, \mathrm{H}^{12,13,14,16,17,18}\right), 3.10\left(\mathrm{~d},{ }^{2} J_{\mathrm{PH}}=8.6 \mathrm{~Hz}\right.$, $\left.2 \mathrm{H}, \mathrm{Ar}-\mathrm{CH}_{2}-\mathrm{P}, \mathrm{H}^{7}\right), 6.42\left(\mathrm{~m}, 1 \mathrm{H}, \mathrm{CH}, \mathrm{H}^{9}\right), 6.81-6.76(2 \mathrm{H}$, $\left.\mathrm{CH} \mathrm{Ar}, \mathrm{H}^{2,4}\right), 6.95\left(\mathrm{~m}, 1 \mathrm{H}, \mathrm{CH} \mathrm{Ar}, \mathrm{H}^{3}\right), 7.58(\mathrm{~m}, 1 \mathrm{H}, \mathrm{CH}$, $\left.\mathrm{H}^{8}\right), 7.85\left(\mathrm{~m}, 1 \mathrm{H}, \mathrm{CH}, \mathrm{H}^{10}\right) \cdot{ }^{13} \mathrm{C}\left\{{ }^{1} \mathrm{H}\right\}$ NMR $(75 \mathrm{MHz}$, $\left.\mathrm{CD}_{2} \mathrm{Cl}_{2}, 293 \mathrm{~K}\right): \delta 29.1\left(\mathrm{~d},{ }^{2} J_{\mathrm{PC}}=3.2 \mathrm{~Hz}, \mathrm{P}-\mathrm{C}\left(\mathrm{CH}_{3}\right)_{3}\right.$, $\left.\mathrm{C}^{12,13,14,16,17,18}\right), 32.9\left(\mathrm{~d},{ }^{1} J_{\mathrm{PC}}=33.2 \mathrm{~Hz}, \mathrm{Ar}-\mathrm{CH}_{2}-\mathrm{P}, \mathrm{C}^{7}\right), 34.5$ $\left(\mathrm{d},{ }^{1} J_{\mathrm{PC}}=13.5 \mathrm{~Hz}, \mathrm{P}-\mathrm{C}\left(\mathrm{CH}_{3}\right)_{3}, \mathrm{C}^{11,15}\right), 107.4\left(\mathrm{C}^{9}\right), 108.3$ $\left(\mathrm{C}^{4}\right), 122.0\left(\mathrm{~d},{ }^{3} J_{\mathrm{PC}}=16.2 \mathrm{~Hz}, \mathrm{C}^{2}\right), 124.6\left(\mathrm{C}^{10}\right), 125.7\left(\mathrm{C}^{3}\right)$, $138.5\left(\mathrm{C}^{8}\right), 139.6\left(\mathrm{C}^{5}\right), 145.3\left(\mathrm{~d}, \mathrm{C}^{1}\right), 152.1\left(\mathrm{~d},{ }^{3} \mathrm{JC}_{\mathrm{PC}}=16.2\right.$ $\left.\mathrm{Hz}, \mathrm{C}^{6}\right) .{ }^{31} \mathrm{P}\left\{{ }^{1} \mathrm{H}\right\}$ NMR $\left(121 \mathrm{MHz}, \mathrm{CD}_{2} \mathrm{Cl}_{2}, 293 \mathrm{~K}\right): \delta 86.1$ (d, $\left.{ }^{2} J_{\mathrm{PF}}=128.8 \mathrm{~Hz}\right) \cdot{ }^{19} \mathrm{~F} \mathrm{NMR}\left(376 \mathrm{MHz}, \mathrm{THF}-d_{8}, 293 \mathrm{~K}\right): \delta$ -374.2. IR $\left(\mathrm{KBr}, \mathrm{cm}^{-1}\right): 501[\nu(\mathrm{Ni}-\mathrm{F})]$. Anal. Calcd (\%) for $\mathrm{C}_{18} \mathrm{H}_{26} \mathrm{FN}_{2} \mathrm{NiP}$ (379.08): C, 57.03; H, 6.91; N, 7.39. Found: C, 57.23; H, 7.02; N, 7.45.

\subsubsection{Synthesis of ( $\left.{ }^{\mathrm{Bu}} \mathrm{PCN}\right) \mathrm{NiCl}(2)$.}

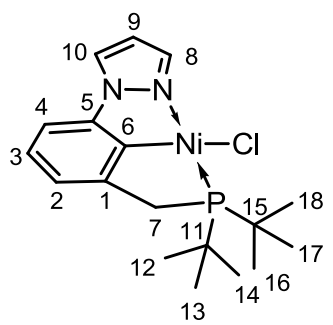

$\mathrm{NEt}_{3}(0.104 \mathrm{~mL}, 0.75 \mathrm{mmol})$ and anhydrous $\mathrm{NiCl}_{2}(0.161 \mathrm{~g}$, $0.98 \mathrm{mmol})$ were added to a solution of PCN $(0.150 \mathrm{~g}, 0.49$ $\mathrm{mmol})$ in dry and degassed toluene $(50 \mathrm{~mL})$. The reaction mixture was then stirred under reflux for $24 \mathrm{~h}$. After cooling, the solution was filtered on cotton to remove the formed $\left(\mathrm{NEt}_{3} \mathrm{H}\right) \mathrm{Cl}$ precipitate and concentrated in vacuo to afford a yellow solid that was washed with pentane and dried in vacuo $(0.186 \mathrm{~g}$, yield $96 \%)$. NMR spectra in $\mathrm{CD}_{2} \mathrm{Cl}_{2}$ are reported in the Supporting Information (Figures S12-S14). Crystals suitable for X-ray diffraction in the form of yellow prisms were obtained from slow evaporation of a THF/EtOH solution of the complex at $273 \mathrm{~K}$.

${ }^{1} \mathrm{H}$ NMR (400 MHz, $\left.\mathrm{CD}_{2} \mathrm{Cl}_{2}, 293 \mathrm{~K}\right): \delta 1.48\left(\mathrm{~d},{ }^{3} \mathrm{~J}_{\mathrm{PH}}=13.4\right.$ $\left.\mathrm{Hz}, 18 \mathrm{H}, \mathrm{P}-\mathrm{C}\left(\mathrm{CH}_{3}\right)_{3}, \mathrm{H}^{12,13,14,16,17,18}\right), 3.20\left(\mathrm{~d},{ }^{2} J_{\mathrm{PH}}=8.8 \mathrm{~Hz}\right.$, $\left.2 \mathrm{H}, \mathrm{Ar}-\mathrm{CH}_{2}-\mathrm{P}, \mathrm{H}^{7}\right), 6.41\left(\mathrm{~m}, 1 \mathrm{H}, \mathrm{CH}, \mathrm{H}^{9}\right), 6.86\left(\mathrm{~d},{ }^{2} J_{\mathrm{HH}}=\right.$ $\left.7.4 \mathrm{~Hz}, 2 \mathrm{H}, \mathrm{CH} \mathrm{Ar}, \mathrm{H}^{2,4}\right), 7.02\left(\mathrm{t},{ }^{2} \mathrm{~J}_{\mathrm{HH}}=7.4 \mathrm{~Hz}, 1 \mathrm{H}, \mathrm{CH} \mathrm{Ar}\right.$, $\left.\mathrm{H}^{3}\right), 7.89-7.86\left(2 \mathrm{H}, \mathrm{CH}, \mathrm{H}^{8,10}\right) .{ }^{13} \mathrm{C}\left\{{ }^{1} \mathrm{H}\right\}$ NMR $(100 \mathrm{MHz}$, $\left.\mathrm{CD}_{2} \mathrm{Cl}_{2}, 293 \mathrm{~K}\right): \delta 29.4$ (br s, $\left.\mathrm{P}-\mathrm{C}\left(\mathrm{CH}_{3}\right)_{3}, \mathrm{C}^{12,13,14,16,17,18}\right)$, $34.6\left(\mathrm{~d},{ }^{1} J_{\mathrm{PC}}=32.4 \mathrm{~Hz}, \operatorname{Ar}-\mathrm{CH}_{2}-\mathrm{P}, \mathrm{C}^{7}\right), 35.0\left(\mathrm{~d},{ }^{1} J_{\mathrm{PC}}=14.4\right.$ $\left.\mathrm{Hz}, \mathrm{P}-\mathrm{C}\left(\mathrm{CH}_{3}\right)_{3}, \mathrm{C}^{11,15}\right), 107.5\left(\mathrm{C}^{9}\right), 108.3\left(\mathrm{C}^{4}\right), 122.0\left(\mathrm{~d},{ }^{3} \mathrm{JC}_{\mathrm{PC}}\right.$ $\left.=16.2 \mathrm{~Hz}, \mathrm{C}^{2}\right), 125.1\left(\mathrm{C}^{10}\right), 125.7\left(\mathrm{C}^{3}\right), 139.5\left(\mathrm{C}^{8}\right), 144.8$ $\left(\mathrm{C}^{5}\right), 145.5\left(\mathrm{~d},{ }^{2} \mathrm{~J}_{\mathrm{PC}}=29.9 \mathrm{~Hz}, \mathrm{C}^{1}\right), 151.5\left(\mathrm{~d},{ }^{3} \mathrm{~J}_{\mathrm{PC}}=16.5 \mathrm{~Hz}\right.$, $\left.\mathrm{C}^{6}\right) .{ }^{31} \mathrm{P}\left\{{ }^{1} \mathrm{H}\right\}$ NMR $\left(161 \mathrm{MHz}, \mathrm{CD}_{2} \mathrm{Cl}_{2}, 293 \mathrm{~K}\right): \delta 87.3$ (s). Anal. Calcd (\%) for $\mathrm{C}_{18} \mathrm{H}_{26} \mathrm{ClN}_{2} \mathrm{NiP}$ (395.53): C, 54.66; $\mathrm{H}$, 6.63; N, 7.08. Found: C, 54.72; H, 6.70; N, 7.10.

\subsubsection{Synthesis of ( $\left.{ }^{\mathrm{Bu}} \mathrm{PCN}\right) \mathrm{NiBr}(3)$.}

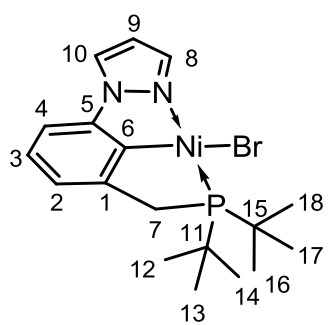

$\mathrm{NEt}_{3}(0.103 \mathrm{~mL}, 0.74 \mathrm{mmol})$ and anhydrous $\mathrm{NiBr}_{2}(0.161 \mathrm{~g}$, $0.74 \mathrm{mmol})$ were added to a solution of PCN $(0.150 \mathrm{~g}, 0.49$ $\mathrm{mmol})$ in dry and degassed toluene $(50 \mathrm{~mL})$. The reaction mixture was then stirred under reflux for $24 \mathrm{~h}$. After cooling, the solution was filtered on cotton to remove the formed $\left(\mathrm{NEt}_{3} \mathrm{H}\right) \mathrm{Br}$ precipitate and concentrated in vacuo to afford a yellow solid that was washed with pentane $(0.210 \mathrm{~g}$, yield 98\%). NMR spectra in $\mathrm{CD}_{2} \mathrm{Cl}_{2}$ are reported in the Supporting Information (Figures S15-S17). Crystals suitable for X-ray diffraction in the form of yellow prisms were obtained from slow evaporation of a THF/EtOH solution of the complex at room temperature. 
${ }^{1} \mathrm{H}$ NMR (300 MHz, $\left.\mathrm{CD}_{2} \mathrm{Cl}_{2}, 293 \mathrm{~K}\right): \delta 1.52\left(\mathrm{~d},{ }^{3} J_{\mathrm{PH}}=13.4\right.$ $\left.\mathrm{Hz}, 18 \mathrm{H}, \mathrm{P}-\mathrm{C}\left(\mathrm{CH}_{3}\right)_{3}, \mathrm{H}^{12,13,14,16,17,18}\right), 3.25\left(\mathrm{~d},{ }^{2} J_{\mathrm{PH}}=8.8 \mathrm{~Hz}\right.$, $\left.2 \mathrm{H}, \mathrm{Ar}-\mathrm{CH}_{2}-\mathrm{P}, \mathrm{H}^{7}\right), 6.41\left(\mathrm{~m}, 1 \mathrm{H}, \mathrm{CH}, \mathrm{H}^{9}\right), 6.86-6.92(2 \mathrm{H}$, $\left.\mathrm{CH} \mathrm{Ar}, \mathrm{H}^{2,4}\right), 7.05\left(\mathrm{~m}, 1 \mathrm{H}, \mathrm{CH} \mathrm{Ar}, \mathrm{H}^{3}\right), 7.90(\mathrm{~m}, 1 \mathrm{H}, \mathrm{CH}$, $\left.\mathrm{H}^{10}\right), 8.13\left(\mathrm{~m}, 1 \mathrm{H}, \mathrm{CH}, \mathrm{H}^{8}\right) .{ }^{13} \mathrm{C}\left\{{ }^{1} \mathrm{H}\right\}$ NMR (75 MHz, $\left.\mathrm{CD}_{2} \mathrm{Cl}_{2}, 293 \mathrm{~K}\right): \delta 29.6\left(\mathrm{~d},{ }^{2} J_{\mathrm{PC}}=2.2 \mathrm{~Hz}, \mathrm{P}-\mathrm{C}\left(\mathrm{CH}_{3}\right)_{3}\right.$, $\left.\mathrm{C}^{12,13,14,16,17,18}\right), 35.1\left(\mathrm{~d},{ }^{1} J_{\mathrm{PC}}=32.2 \mathrm{~Hz}, \mathrm{Ar}-\mathrm{CH}_{2}-\mathrm{P}, \mathrm{C}^{7}\right), 35.3$ $\left(\mathrm{d},{ }^{1} J_{\mathrm{PC}}=14.6 \mathrm{~Hz}, \mathrm{P}-\mathrm{C}\left(\mathrm{CH}_{3}\right)_{3}, \mathrm{C}^{11,15}\right), 107.8\left(\mathrm{C}^{9}\right), 108.4$ $\left(\mathrm{C}^{4}\right), 122.1\left(\mathrm{~d},{ }^{3} J_{\mathrm{PC}}=16.3 \mathrm{~Hz}, \mathrm{C}^{2}\right), 125.3\left(\mathrm{C}^{10}\right), 125.9\left(\mathrm{C}^{3}\right)$, $141.1\left(\mathrm{C}^{8}\right), 144.8\left(\mathrm{C}^{5}\right), 147.0\left(\mathrm{~d},{ }^{2} J_{\mathrm{PC}}=29.5 \mathrm{~Hz}, \mathrm{C}^{1}\right), 151.4$ $\left(\mathrm{d},{ }^{3} J_{\mathrm{PC}}=16.1 \mathrm{~Hz}, \mathrm{C}^{6}\right) .{ }^{31} \mathrm{P}\left\{{ }^{1} \mathrm{H}\right\}$ NMR $\left(121 \mathrm{MHz}, \mathrm{CD}_{2} \mathrm{Cl}_{2}\right.$, $293 \mathrm{~K}): \delta 88.7$ (s). Anal. Calcd (\%) for $\mathrm{C}_{18} \mathrm{H}_{26} \mathrm{BrN}_{2} \mathrm{NiP}$ (439.98): C, 49.14; H, 5.96; N, 6.37. Found: C, 49.23; H, 6.03; $\mathrm{N}, 6.39$.

\subsubsection{Synthesis of ( $\left.{ }^{\mathrm{Bu}} \mathrm{PCN}\right) \mathrm{Nil}(4)$.}

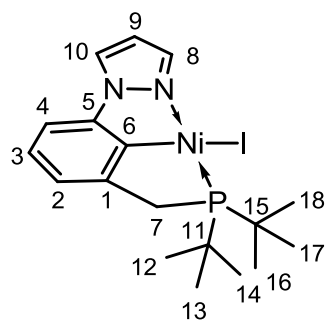

$\mathrm{NEt}_{3}(0.104 \mathrm{~mL}, 0.75 \mathrm{mmol})$ and anhydrous $\mathrm{NiI}_{2}(0.235 \mathrm{~g}$, $0.75 \mathrm{mmol})$ were added to a solution of PCN $(0.150 \mathrm{~g}, 0.49$ $\mathrm{mmol})$ in dry and degassed toluene $(50 \mathrm{~mL})$. The reaction mixture was then stirred under reflux for $24 \mathrm{~h}$. After cooling, the solution was filtered on cotton to remove the formed $\left(\mathrm{NEt}_{3} \mathrm{H}\right) \mathrm{I}$ precipitate and concentrated in vacuo to afford a yellow solid that was washed with pentane $(0.220 \mathrm{~g}$, yield 92\%). NMR spectra in $\mathrm{CD}_{2} \mathrm{Cl}_{2}$ are reported in the Supporting Information (Figures S18-S20). Crystals suitable for X-ray diffraction in the form of dark yellow prisms were obtained from slow evaporation of a THF/EtOH solution of the complex at room temperature.

${ }^{1} \mathrm{H}$ NMR $\left(300 \mathrm{MHz}, \mathrm{CD}_{2} \mathrm{Cl}_{2}, 293 \mathrm{~K}\right): \delta 1.50\left(\mathrm{~d},{ }^{3} \mathrm{JH}_{\mathrm{PH}}=13.4\right.$ $\left.\mathrm{Hz}, 18 \mathrm{H}, \mathrm{P}-\mathrm{C}\left(\mathrm{CH}_{3}\right)_{3}, \mathrm{H}^{12,13,14,16,17,18}\right), 3.29\left(\mathrm{~d},{ }^{2} J_{\mathrm{PH}}=8.8 \mathrm{~Hz}\right.$, $\left.2 \mathrm{H}, \mathrm{Ar}-\mathrm{CH}_{2}-\mathrm{P}, \mathrm{H}^{7}\right), 6.37\left(\mathrm{~m}, 1 \mathrm{H}, \mathrm{CH}, \mathrm{H}^{9}\right), 6.86\left(\mathrm{~d},{ }^{2} J_{\mathrm{HH}}=\right.$ $\left.7.6 \mathrm{~Hz}, 1 \mathrm{H}, \mathrm{CH} \mathrm{Ar}, \mathrm{H}^{4}\right), 6.93\left(\mathrm{~d},{ }^{2} \mathrm{~J}_{\mathrm{HH}}=7.4 \mathrm{~Hz}, 1 \mathrm{H}, \mathrm{CH} \mathrm{Ar}\right.$, $\left.\mathrm{H}^{2}\right), 7.06\left(\mathrm{~m}, 1 \mathrm{H}, \mathrm{CH} \mathrm{Ar}, \mathrm{H}^{3}\right), 7.92\left(\mathrm{~m}, 1 \mathrm{H}, \mathrm{CH}, \mathrm{H}^{10}\right), 8.47$ $\left(\mathrm{m}, 1 \mathrm{H}, \mathrm{CH}, \mathrm{H}^{8}\right) \cdot{ }^{13} \mathrm{C}\left\{{ }^{1} \mathrm{H}\right\} \mathrm{NMR}\left(75 \mathrm{MHz}, \mathrm{CD}_{2} \mathrm{Cl}_{2}, 293 \mathrm{~K}\right): \delta$ $29.9\left(\mathrm{~d},{ }^{2} \mathrm{JC}_{\mathrm{PC}}=2.2 \mathrm{~Hz}, \mathrm{P}-\mathrm{C}\left(\mathrm{CH}_{3}\right)_{3}, \mathrm{C}^{12,13,14,16,17,18}\right), 35.4(\mathrm{~d}$, $\left.{ }^{1} J_{\mathrm{PC}}=14.7 \mathrm{~Hz}, \mathrm{P}-\mathrm{C}\left(\mathrm{CH}_{3}\right)_{3}, \mathrm{C}^{11,15}\right), 35.6\left(\mathrm{~d},{ }^{1} \mathrm{~J}_{\mathrm{PC}}=32.1 \mathrm{~Hz}\right.$, Ar- $\left.\mathrm{CH}_{2}-\mathrm{P}, \mathrm{C}^{7}\right), 108.2\left(\mathrm{C}^{9}\right), 108.5\left(\mathrm{C}^{4}\right), 122.0\left(\mathrm{~d},{ }^{3} J_{\mathrm{PC}}=16.1\right.$ $\left.\mathrm{Hz}, \mathrm{C}^{2}\right), 125.7\left(\mathrm{C}^{10}\right), 125.9\left(\mathrm{C}^{3}\right), 144.3\left(\mathrm{C}^{8}\right), 144.5\left(\mathrm{C}^{5}\right)$, $149.7\left(\mathrm{~d},{ }^{2} J_{\mathrm{PC}}=28.5 \mathrm{~Hz}, \mathrm{C}^{1}\right), 150.9\left(\mathrm{~d},{ }^{3} J_{\mathrm{PC}}=16.1 \mathrm{~Hz}, \mathrm{C}^{6}\right)$. ${ }^{31} \mathrm{P}\left\{{ }^{1} \mathrm{H}\right\}$ NMR $\left(121 \mathrm{MHz}, \mathrm{CD}_{2} \mathrm{Cl}_{2}, 293 \mathrm{~K}\right): \delta 91.7$ (s). Anal. Calcd (\%) for $\mathrm{C}_{18} \mathrm{H}_{26} \mathrm{IN}_{2} \mathrm{NiP}$ (486.98): C, 44.39; H, 5.38; N, 5.75. Found: C, 44.50; H, 5.42; N, 5.81.

4.2. Crystal Data Collection. Single-crystal X-ray data for 1-4 were collected at low temperature $(T=100$ or $150 \mathrm{~K})$ on Oxford Diffraction XcaliburPX diffractometers equipped with a charge-coupled device area detector using $\mathrm{Cu} \mathrm{K} \alpha(\lambda=1.5418$ $\AA)$ or Mo $\mathrm{K} \alpha(\lambda=0.7107 \AA)$ radiation. The program used for the data collection was CrysAlis CCD $1.171 .^{80}$ Data reduction was carried out with the program CrysAlis RED $1.171,{ }^{81}$ and the absorption correction was applied with the program ABSPACK 1.17. Direct methods implemented in Sir97 ${ }^{82}$ were used to solve the structures, and the refinements were performed by full-matrix least-squares against $F^{2}$ implemented in SHELX2014. ${ }^{83}$ All non-hydrogen atoms were refined anisotropically, whereas the hydrogen atoms were fixed in calculated positions and refined isotropically with the thermal factor depending on one of the atoms to which they are bound. The $\mathrm{H}$ atoms on the water molecule in the structure of 1 $[\mathrm{H}(100)$ and $\mathrm{H}(101)$, Figure 2] were located in the residual electron density maps and refined isotropically against $\mathrm{O}(1)$. The geometrical calculations were performed by PARST $97,{ }^{84}$ and molecular plots were produced by the program ORTEP3. ${ }^{85}$ CCDC 1868355 (1), 1868356 (2), 1868357 (3), and 1868358 (4) contain the supplementary crystallographic data for this paper.

4.3. ${ }^{19} \mathrm{~F}$ VT-NMR Study of the Halogen Bonding Between $1 /\left({ }^{\text {Bu }} \mathrm{PCP}\right) \mathrm{NiF}$ and IPFB. The equilibrium constants for 1 and $\left({ }^{t \mathrm{Bu}} \mathrm{PCP}\right) \mathrm{NiF}$ were determined through ${ }^{19} \mathrm{~F}$ NMR. The chemical shift of the fluoride ligand coordinated to nickel was followed in a series of titrations with IPFB at various temperatures $(T=233,253,273,293$, and $313 \mathrm{~K})$. Solutions of 1 and $\left({ }^{t \mathrm{Bu}} \mathrm{PCP}\right) \mathrm{NiF}\left(1.00 \times 10^{-2} \mathrm{M}\right)$ were prepared by dissolving the related complex in THF- $d_{8}$. Such solutions $(0.600 \mathrm{~mL})$ were titrated by subsequent additions of neat IPFB in quantities ranging from $0.4 \mu \mathrm{L}$ up to $16.0 \mu \mathrm{L}$. The volume of the solutions was assumed to be the sum of the volumes of the components. For each spectrum, the temperature of the samples was left to equilibrate inside the probe at least for 10 min before the spectrum acquisition. For the Job plots, $1.00 \times$ $10^{-2} \mathrm{M}$ stock solutions of IPFB, $\mathbf{1}$, and ( $\left.{ }^{t \mathrm{Bu}} \mathrm{PCP}\right) \mathrm{NiF}$ in THF$d_{8}$ were prepared. NMR tubes were prepared with measured aliquots of each solution so that the total volume in the tube was $0.600 \mathrm{~mL}$.

4.4. Electrochemical and EPR Measurements on 1-4. Cyclic voltammograms were recorded with a GC electrode (working surface $3.14 \mathrm{~cm}^{2}$ ) in a thermostatically controlled ( $T$ $=293 \mathrm{~K}$ ) three-electrode electrochemical cell under $\mathrm{N}_{2}$ in the presence of $\left(\mathrm{NBu}_{4}\right) \mathrm{BF}_{4}(0.1 \mathrm{M})$. A silver electrode $\mathrm{Ag} / \mathrm{AgNO}_{3}$ $\left(0.01 \mathrm{~mol} \cdot \mathrm{L}^{-1}\right.$ solution in $\left.\mathrm{CH}_{3} \mathrm{CN}\right)$ was used as a reference electrode, and a platinum wire served as an auxiliary electrode. Curves were recorded at a constant potential scan rate of 50 $\mathrm{mV} \cdot \mathrm{s}^{-1}$ using an E14-440 analog-to-digital converter and a potentiostat/galvanostat PI-50-1. The EPR measurements were performed with a Bruker EMX spectrometer operational in the X-band.

4.5. Computational Methods. All calculations were performed by the Gaussian 09 (G09) program package ${ }^{86}$ employing the density functional theory method ${ }^{87}$ with a PBE0 functional. ${ }^{88}$ The LanL2DZ effective core potential and the related basis set $^{89}$ was used for the nickel atom, and the 6$31 \mathrm{G}^{* *}$ basis set ${ }^{90}$ was used for all the other atoms. Geometry optimizations were carried out without any symmetry constraints. The nature of all stationary points was verified by using harmonic vibrational frequency calculations. No imaginary frequencies were found, thus indicating that we had located the minima on the potential energy surfaces. EPSs are shown in space as well as mapped on electron density (isovalue 0.001 ) of the molecules.

\section{ASSOCIATED CONTENT}

\section{Supporting Information}

The Supporting Information is available free of charge on the ACS Publications website at DOI: 10.1021/acsomega.8b02452. 
Selected bond distances and angles for complexes 1-4 and comparison of experimental and simulated EPR spectra for complexes $1-4$ (PDF)

\section{AUTHOR INFORMATION}

\section{Corresponding Authors}

*E-mail: michele.chierotti@unito.it (M.R.C.).

*E-mail: yakhvar@iopc.ru (D.Y.).

*E-mail: a.rossin@iccom.cnr.it (A.R.).

*E-mail: giuliano.giambastiani@iccom.cnr.it (G.G.).

\section{ORCID}

Claudio Garino: 0000-0002-7854-6076

Paolo Cerreia Vioglio: 0000-0001-9546-7911

Roberto Gobetto: 0000-0002-2431-8051

Michele R. Chierotti: 0000-0002-8734-6009

Andrea Rossin: 0000-0002-1283-2803

Giuliano Giambastiani: 0000-0002-0315-3286

Notes

The authors declare no competing financial interest.

\section{ACKNOWLEDGMENTS}

The bilateral project CNR (Italy)-RFBR (Russian Federation) 2015-2017 (RFBR grant no. 15-53-78027) is acknowledged for the financial support. G.G. would also like to thank the Italian MIUR through the PRIN 2015 Project SMARTNESS (2015K7FZLH) "Solar driven chemistry: new materials for photo- and electro-catalysis" for the financial help. This work is performed according to the Russian Government Program of Competitive Growth of Kazan Federal University. The study of the electrochemical properties of the reported complexes was funded by RFBR according to the research project no. 18-33-00177. C.G., R.G., and M.R.C. are indebted to Jeol Company for helpful technical assistance and cooperation.

\section{REFERENCES}

(1) Metrangolo, P.; Carcenac, Y.; Lahtinen, M.; Pilati, T.; Rissanen, K.; Vij, A.; Resnati, G. Nonporous Organic Solids Capable of Dynamically Resolving Mixtures of Diiodoperfluoroalkanes. Science 2009, 323, 1461-1464.

(2) Metrangolo, P.; Meyer, F.; Pilati, T.; Resnati, G.; Terraneo, G. Halogen Bonding in Supramolecular Chemistry. Angew. Chem., Int. Ed. 2008, 47, 6114-6127.

(3) Metrangolo, P.; Resnati, G. Halogen Bonding: Fundamentals and Applications, Structure \& Bonding; Springer: Berlin, 2007.

(4) Metrangolo, P.; Neukirch, H.; Pilati, T.; Resnati, G. Halogen Bonding Based Recognition Processes: A World Parallel to Hydrogen Bonding $\dagger$. Acc. Chem. Res. 2005, 38, 386-395.

(5) Steiner, T. The Hydrogen Bond in the Solid State. Angew. Chem., Int. Ed. 2002, 41, 48-76.

(6) Brammer, L.; Bruton, E. A.; Sherwood, P. Understanding the Behavior of Halogens as Hydrogen Bond Acceptors. Cryst. Growth Des. 2001, 1, 277-290.

(7) Desiraju, G. R.; Steiner, T. The Weak Hydrogen Bond; Oxford University Press, 1999.

(8) Parisini, E.; Metrangolo, P.; Pilati, T.; Resnati, G.; Terraneo, G. Halogen bonding in halocarbon-protein complexes: a structural survey. Chem. Soc. Rev. 2011, 40, 2267-2278.

(9) Shirman, T.; Arad, T.; van der Boom, M. E. Halogen Bonding: A Supramolecular Entry for Assembling Nanoparticles. Angew. Chem., Int. Ed. 2009, 49, 926-929.

(10) Kilah, N. L.; Wise, M. D.; Serpell, C. J.; Thompson, A. L.; White, N. G.; Christensen, K. E.; Beer, P. D. Enhancement of Anion
Recognition Exhibited by a Halogen-Bonding Rotaxane Host System. J. Am. Chem. Soc. 2010, 132, 11893-11895.

(11) Yamamoto, H. M.; Kosaka, Y.; Maeda, R.; Yamaura, J.-i.; Nakao, A.; Nakamura, T.; Kato, R. Supramolecular Insulating Networks Sheathing Conducting Nanowires Based on Organic Radical Cations. ACS Nano 2008, 2, 143-155.

(12) Präsang, C.; Whitwood, A. C.; Bruce, D. W. Spontaneous Symmetry-Breaking in Halogen-Bonded, Bent-Core Liquid Crystals: Observation of a Chemically Driven Iso-N-N* Phase Sequence. Chem. Commun. 2008, 0, 2137-2139.

(13) Sun, A.; Lauher, J. W.; Goroff, N. S. Preparation of Poly(diiododiacetylene), an Ordered Conjugated Polymer of Carbon and Iodine. Science 2006, 312, 1030-1034.

(14) Nguyen, H. L.; Horton, P. N.; Hursthouse, M. B.; Legon, A. C.; Bruce, D. W. Halogen Bonding: A New Interaction for Liquid Crystal Formation. J. Am. Chem. Soc. 2004, 126, 16-17.

(15) Corradi, E.; Meille, S. V.; Messina, M. T.; Metrangolo, P.; Resnati, G. Halogen Bonding versus Hydrogen Bonding in Driving Self-Assembly Processes. Angew. Chem., Int. Ed. 2000, 39, 1782-1786.

(16) Cavallo, G.; Metrangolo, P.; Milani, R.; Pilati, T.; Priimagi, A.; Resnati, G.; Terraneo, G. The Halogen Bond. Chem. Rev. 2016, 116, 2478-2601.

(17) Clark, T.; Hennemann, M.; Murray, J. S.; Politzer, P. Halogen bonding: the $\sigma$-hole. J. Mol. Model. 2006, 13, 291-296.

(18) Rauch, M.; Ruccolo, S.; Mester, J. P.; Rong, Y.; Parkin, G. Synthesis, Structure and Reactivity of a Terminal Magnesium Fluoride Compound, $\left[\mathrm{Tp}^{\mathrm{But}, \mathrm{Me}}\right] \mathrm{MgF}$ : Hydrogen Bonding, Halogen Bonding and C-F Bond Formation. Chem. Sci. 2016, 7, 142-149.

(19) Smith, D. A.; Beweries, T.; Blasius, C.; Jasim, N.; Nazir, R.; Nazir, S.; Robertson, C. C.; Whitwood, A. C.; Hunter, C. A.; Brammer, L.; Perutz, R. N. The Contrasting Character of Early and Late Transition Metal Fluorides as Hydrogen Bond Acceptors. J. Am. Chem. Soc. 2015, 137, 11820-11831.

(20) Sattler, W.; Ruccolo, S.; Parkin, G. Synthesis, Structure, and Reactivity of a Terminal Organozinc Fluoride Compound: Hydrogen Bonding, Halogen Bonding, and Donor-Acceptor Interactions. J. Am. Chem. Soc. 2013, 135, 18714-18717.

(21) Clot, E.; Eisenstein, O.; Jasim, N.; Macgregor, S. A.; McGrady, J. E.; Perutz, R. N. $\mathrm{C}-\mathrm{F}$ and $\mathrm{C}-\mathrm{H}$ Bond Activation of Fluorobenzenes and Fluoropyridines at Transition Metal Centers: How Fluorine Tips the Scales. Acc. Chem. Res. 2011, 44, 333-348.

(22) Macgregor, S. A.; Roe, D. C.; Marshall, W. J.; Bloch, K. M.; Bakhmutov, V. I.; Grushin, V. V. The F/Ph Rearrangement Reaction of $\left[\left(\mathrm{Ph}_{3} \mathrm{P}\right)_{3} \mathrm{RhF}\right]$, the Fluoride Congener of Wilkinson's Catalyst. J. Am. Chem. Soc. 2005, 127, 15304-15321.

(23) Braun, T.; Perutz, R. N. Transition-Metal Mediated C-F Bond Activation. In Comprehensive Organometallic Chemistry III; Crabtree, R. H.; Mingos, D. M. P., Eds.; Elsevier: Amsterdam, 2001; Vol. 1, Chapter 26.

(24) Mínguez Espallargas, G.; Brammer, L.; Sherwood, P. Designing Intermolecular Interactions between Halogenated Peripheries of Inorganic and Organic Molecules: Electrostatically Directed M-X... $\mathrm{X}^{\prime}-\mathrm{C}$ Halogen Bonds. Angew. Chem., Int. Ed. 2006, 45, 435-440.

(25) Zordan, F.; Brammer, L.; Sherwood, P. Supramolecular Chemistry of Halogens: Complementary Features of Inorganic (M$\mathrm{X})$ and Organic $\left(\mathrm{C}-\mathrm{X}^{\prime}\right)$ Halogens Applied to $\mathrm{M}-\mathrm{X} \cdots \mathrm{X}$ - $-\mathrm{C}$ Halogen Bond Formation. J. Am. Chem. Soc. 2005, 127, 5979-5989.

(26) Ghassemzadeh, M.; Harms, K.; Dehnicke, K. Complexes of Halide Ions with 1-Halogen-2-phenylacetylenes. Crystal Structures of $\mathrm{PPh}_{4}\left[\mathrm{X}(\mathrm{I}-\mathrm{CC}-\mathrm{Ph})_{4}\right]$ with $\mathrm{X}=\mathrm{Cl}, \mathrm{Br}$, I, of $\mathrm{PPh}_{4}\left[\mathrm{Br}(\mathrm{Br}-\mathrm{CC}-\mathrm{Ph})_{4}\right]$, and of $\mathrm{NMe}_{4}\left[\mathrm{~F}(\mathrm{I}-\mathrm{CC}-\mathrm{Ph})_{2}\right]$. Chem. Ber. 1996, 129, 115-120.

(27) Drews, T.; Marx, R.; Seppelt, K. Cesium Fluoride-Bromine Intercalation Compounds. Chem.-Eur. J. 1996, 2, 1303-1307.

(28) Smith, D. A.; Brammer, L.; Hunter, C. A.; Perutz, R. N. Metal Hydrides Form Halogen Bonds: Measurement of Energetics of Binding. J. Am. Chem. Soc. 2014, 136, 1288-1291.

(29) Chierotti, M. R.; Rossin, A.; Gobetto, R.; Peruzzini, M. Interaction between a Transition-Metal Fluoride and a Transition- 
Metal Hydride: Water-Mediated Hydrofluoric Acid Evolution

Following Fluoride Solvation. Inorg. Chem. 2013, 52, 12616-12623.

(30) Beweries, T.; Brammer, L.; Jasim, N. A.; McGrady, J. E.; Perutz, R. N.; Whitwood, A. C. Energetics of Halogen Bonding of Group 10 Metal Fluoride Complexes. J. Am. Chem. Soc. 2011, 133, 1433814348.

(31) Libri, S.; Jasim, N. A.; Perutz, R. N.; Brammer, L. Metal Fluorides Form Strong Hydrogen Bonds and Halogen Bonds: Measuring Interaction Enthalpies and Entropies in Solution. J. Am. Chem. Soc. 2008, 130, 7842-7844.

(32) Jasim, N. A.; Perutz, R. N.; Whitwood, A. C.; Braun, T.; Izundu, J.; Neumann, B.; Rothfeld, S.; Stammler, H.-G. Contrasting Reactivity of Fluoropyridines at Palladium and Platinum: $\mathrm{C}-\mathrm{F}$ Oxidative Addition at Palladium, $\mathrm{P}-\mathrm{C}$ and $\mathrm{C}-\mathrm{F}$ Activation at Platinum. Organometallics 2004, 23, 6140-6149.

(33) Gafurov, Z. N.; Sinyashin, O. G.; Yakhvarov, D. G. Electrochemical Methods for Synthesis of Organoelement Compounds and Functional Materials. Pure Appl. Chem. 2017, 89, 10891103.

(34) Yakhvarov, D. G.; Khusnuriyalova, A. F.; Sinyashin, O. G. Electrochemical Synthesis and Properties of Organonickel $\sigma$ Complexes. Organometallics 2014, 33, 4574-4589.

(35) Budnikova, Y. H.; Yakhvarov, D. G.; Sinyashin, O. G. Electrocatalytic Eco-Efficient Functionalization of White Phosphorus. J. Organomet. Chem. 2005, 690, 2416-2425.

(36) Yakhvarov, D. G.; Budnikova, Y. G.; Sinyashin, O. G. Organonickel $\sigma$-Complexes - Key Intermediates of Electrocatalytic Cycles. Russ. J. Electrochem. 2003, 39, 1261-1270.

(37) Bailey, W. D.; Luconi, L.; Rossin, A.; Yakhvarov, D.; Flowers, S. E.; Kaminsky, W.; Kemp, R. A.; Giambastiani, G.; Goldberg, K. I. Pyrazole-Based PCN Pincer Complexes of Palladium(II): Mono- and Dinuclear Hydroxide Complexes and Ligand Rollover C-H Activation. Organometallics 2015, 34, 3998-4010.

(38) Rossin, A.; Peruzzini, M.; Zanobini, F. Nickel(II) Hydride and Fluoride Pincer Complexes and their Reactivity with Lewis Acids $\mathrm{BX}_{3}$. $\mathrm{L}\left(\mathrm{X}=\mathrm{H}, \mathrm{L}=\right.$ thf; $\left.\mathrm{X}=\mathrm{F}, \mathrm{L}=\mathrm{Et}_{2} \mathrm{O}\right)$. Dalton Trans. 2011, 40, 44474452.

(39) Shao, D.-D.; Niu, J.-L.; Hao, X.-Q.; Gong, J.-F.; Song, M.-P. Neutral and cationic chiral NCN pincer nickel(II) complexes with 1,3-bis (2'-imidazolinyl)benzenes: synthesis and characterization. Dalton Trans. 2011, 40, 9012-9019.

(40) Zhou, W.; Zheng, S.; Schultz, J. W.; Rath, N. P.; Mirica, L. M. Aromatic Cyanoalkylation through Double C-H Activation Mediated by $\mathrm{Ni}(\mathrm{III})$. J. Am. Chem. Soc. 2016, 138, 5777-5780.

(41) Vabre, B.; Petiot, P.; Declercq, R.; Zargarian, D. Fluoro and Trifluoromethyl Derivatives of POCOP-Type Pincer Complexes of Nickel: Preparation and Reactivities in $\mathrm{S}_{\mathrm{N}} 2$ Fluorination and Direct Benzylation of Unactivated Arenes. Organometallics 2014, 33, 51735184

(42) Martínez-Prieto, L. M.; Melero, C.; del Río, D.; Palma, P.; Cámpora, J.; Álvarez, E. Synthesis and Reactivity of Nickel and Palladium Fluoride Complexes with PCP Pincer Ligands. NMR-Based Assessment of Electron-Donating Properties of Fluoride and Other Monoanionic Ligands. Organometallics 2012, 31, 1425-1438.

(43) Yang, M.-J.; Liu, Y.-J.; Gong, J.-F.; Song, M.-P. Unsymmetrical Chiral PCN Pincer Palladium(II) and Nickel(II) Complexes with Aryl-Based Aminophosphine-Imidazoline Ligands: Synthesis via Aryl $\mathrm{C}-\mathrm{H}$ Activation and Asymmetric Addition of Diarylphosphines to Enones. Organometallics 2011, 30, 3793-3803.

(44) Sanford, J.; Dent, C.; Masuda, J. D.; Xia, A. Synthesis, Characterization and Application of Pincer-Type Nickel Iminophosphinite Complexes. Polyhedron 2011, 30, 1091-1094.

(45) Zhang, B.-S.; Wang, W.; Shao, D.-D.; Hao, X.-Q.; Gong, J.-F.; Song, M.-P. Unsymmetrical Chiral PCN Pincer Palladium(II) and Nickel(II) Complexes of (Imidazolinyl)aryl Phosphinite Ligands: Synthesis via Ligand $\mathrm{C}-\mathrm{H}$ Activation, Crystal Structures, and Catalytic Studies. Organometallics 2010, 29, 2579-2587.

(46) Niu, J.-L.; Chen, Q.-T.; Hao, X.-Q.; Zhao, Q.-X.; Gong, J.-F.; Song, M.-P. Diphenylprolinol-Derived Symmetrical and Unsym- metrical Chiral Pincer Palladium(II) and Nickel(II) Complexes: Synthesis via One-Pot Phosphorylation/Metalation Reaction and CH Activation. Organometallics 2010, 29, 2148-2156.

(47) Smith, J. B.; Miller, A. J. M. Connecting Neutral and Cationic Pathways in Nickel-Catalyzed Insertion of Benzaldehyde into a C-H Bond of Acetonitrile. Organometallics 2015, 34, 4669-4677.

(48) Mougang-Soumé, B.; Belanger-Gariépy, F.; Zargarian, D. Synthesis, Characterization, and Oxidation of New $\mathrm{POCN}_{\text {imine }}$-Type Pincer Complexes of Nickel. Organometallics 2014, 33, 5990-6002.

(49) Spasyuk, D. M.; Gorelsky, S. I.; van der Est, A.; Zargarian, D. Characterization of Divalent and Trivalent Species Generated in the Chemical and Electrochemical Oxidation of a Dimeric Pincer Complex of Nickel. Inorg. Chem. 2011, 50, 2661-2674.

(50) Spasyuk, D. M.; Zargarian, D. Monomeric and Dimeric Nickel Complexes Derived from a Pincer Ligand Featuring a Secondary Amine Donor Moiety. Inorg. Chem. 2010, 49, 6203-6213.

(51) Spasyuk, D. M.; Zargarian, D.; van der Est, A. New POCNType Pincer Complexes of Nickel(II) and Nickel(III). Organometallics 2009, 28, 6531-6540.

(52) Ananthnag, G. S.; Mague, J. T.; Balakrishna, M. S. A Cyclodiphosphazane Based Pincer Ligand, [2,6-\{ $\mu$ - $\left({ }^{\mathrm{t}} \mathrm{BuN}\right)_{2} \mathrm{P}$ $\left.\left.\left({ }^{\mathrm{t}} \mathrm{BuHN}\right) \mathrm{PO}\right\}_{2} \mathrm{C}_{6} \mathrm{H}_{3} \mathrm{I}\right]: \mathrm{Ni}^{\mathrm{iI}}, \mathrm{Pd}^{\mathrm{II}}, \mathrm{Pt}^{\mathrm{II}}$ and $\mathrm{Cu}^{\mathrm{I}}$ Complexes and Catalytic Studies. Dalton Trans. 2015, 44, 3785-3793.

(53) Salah, A.; Zargarian, D. \{2,6-Bis[(Diphenylphosphanyl)Oxy]Phenyl- $\left.\kappa^{3} \mathrm{P}, \mathrm{C}^{1}, \mathrm{P}^{\prime}\right\}$ Iodidonickel(II). Acta Crystallogr., Sect. E: Struct. Rep. Online 2011, 67, m437.

(54) Pandarus, V.; Zargarian, D. New Pincer-Type Diphosphinito (POCOP) Complexes of Nickel. Organometallics 2007, 26, 43214334.

(55) van der Boom, M. E.; Liou, S.-Y.; Shimon, L. J. W.; Ben-David, Y.; Milstein, D. Nickel promoted C-H, C-C and C-O bond activation in solution. Inorg. Chim. Acta 2004, 357, 4015-4023.

(56) Fossey, J. S.; Richards, C. J. Synthesis and X-Ray Crystal Structure Analysis of the First Nickel Bisoxazoline Pincer Complex. J. Organomet. Chem. 2004, 689, 3056-3059.

(57) Grove, D. M.; Van Koten, G.; Zoet, R.; Murrall, N. W.; Welch, A. J. Unique Stable Organometallic Nickel(III) Complexes; Syntheses and the Molecular Structure of $\left[\mathrm{Ni}\left[\mathrm{C}_{6} \mathrm{H}_{3}\left(\mathrm{CH}_{2} \mathrm{NMe}_{2}\right)_{2}-0, o^{\prime}\right] \mathrm{I}_{2}\right]$. J. Am. Chem. Soc. 1983, 105, 1379-1380.

(58) Aakeröy, C. B.; Beer, P. D.; Beyeh, N. K.; Brammer, L.; Branca, M.; Bryce, D. L.; Del Bene, J. E.; Edwards, A. J.; Erdelyi, M.; Esterhuysen, C.; Fourmigué, M.; Kennepohl, P.; Lee, L. M.; Mosquera, M. E. G.; Murray, J. S.; Mustoe, C. L.; Pennington, W. T.; Politzer, P.; Riley, K. E.; Rosokha, S. V.; Scheiner, S.; Taylor, M. S.; Tsuzuki, S.; Vargas-Baca, I.; Xu, Y. The Halogen Bond in Solution: General Discussion. Faraday Discuss. 2017, 203, 347-370.

(59) Robertson, C. C.; Wright, J. S.; Carrington, E. J.; Perutz, R. N.; Hunter, C. A.; Brammer, L. Hydrogen Bonding vs. Halogen Bonding: the Solvent Decides. Chem. Sci. 2017, 8, 5392-5398.

(60) Cerreia Vioglio, P.; Szell, P. M. J.; Chierotti, M. R.; Gobetto, R.; Bryce, D. L. ${ }^{79 / 81} \mathrm{Br}$ Nuclear Quadrupole Resonance Spectroscopic Characterization of Halogen Bonds in Supramolecular Assemblies. Chem. Sci. 2018, 9, 4555-4561.

(61) Cerreia Vioglio, P.; Catalano, L.; Vasylyeva, V.; Nervi, C.; Chierotti, M. R.; Resnati, G.; Gobetto, R.; Metrangolo, P. Natural Abundance ${ }^{15} \mathrm{~N}$ and ${ }^{13} \mathrm{C}$ Solid-State NMR Chemical Shifts: High Sensitivity Probes of the Halogen Bond Geometry. Chem.-Eur. J. 2016, 22, 16819-16828.

(62) Vioglio, P. C.; Chierotti, M. R.; Gobetto, R. Solid-state Nuclear Magnetic Resonance as a Tool for Investigating the Halogen Bond. CrystEngComm 2016, 18, 9173-9184.

(63) Bryce, D. L.; Viger-Gravel, J. Solid-state NMR study of halogenbonded adducts. Top. Curr. Chem. 2015, 358, 183-203.

(64) Valerio, G.; Raos, G.; Meille, S. V.; Metrangolo, P.; Resnati, G. Halogen Bonding in Fluoroalkylhalides: A Quantum Chemical Study of Increasing Fluorine Substitution. J. Phys. Chem. A 2000, 104, $1617-1620$

(65) Olson, E. J.; Bühlmann, P. Getting More out of a Job Plot: Determination of Reactant to Product Stoichiometry in Cases of 
Displacement Reactions and n:n Complex Formation. J. Org. Chem. 2011, 76, 8406-8412.

(66) Shukla, S.; Loc, N. H.; Boix, P. P.; Koh, T. M.; Prabhakar, R. R.; Mulmudi, H. K.; Zhang, J.; Chen, S.; Ng, C. F.; Huan, C. H. A.; Mathews, N.; Sritharan, T.; Xiong, Q. Iron Pyrite Thin Film Counter Electrodes for Dye-Sensitized Solar Cells: High Efficiency for Iodine and Cobalt Redox Electrolyte Cells. ACS Nano 2014, 8, 1059710605.

(67) El-Hallag, I. S. Electrochemical Oxidation of Iodide at a Glassy Carbon Electrode in Methylene Chloride at Various Temperatures. J. Chil. Chem. Soc. 2010, 55, 57-63.

(68) Schultz, J. W.; Fuchigami, K.; Zheng, B.; Rath, N. P.; Mirica, L. M. Isolated Organometallic Nickel(III) and Nickel(IV) Complexes Relevant to Carbon-Carbon Bond Formation Reactions. J. Am. Chem. Soc. 2016, 138, 12928-12934.

(69) Zhou, W.; Schultz, J. W.; Rath, N. P.; Mirica, L. M. Aromatic Methoxylation and Hydroxylation by Organometallic High-Valent Nickel Complexes. J. Am. Chem. Soc. 2015, 137, 7604-7607.

(70) Liu, H.; Shen, W.; Quayle, W. H.; Lunsford, J. H. Study of Trans-Dichlorobis(Ethylenediamine)Nickel(III) in Zeolite Y. Inorg. Chem. 1984, 23, 4553-4556.

(71) Kuwamura, N.; Kitano, K. i.; Hirotsu, M.; Nishioka, T.; Teki, Y.; Santo, R.; Ichimura, A.; Hashimoto, H.; Wright, L. J.; Kinoshita, I. Redox-Controlled, Reversible Rearrangement of a Tris(2pyridylthio)methyl Ligand on Nickel to an Isomer with an "N,SConfused" 2-Pyridylthiolate Arm. Chem.-Eur. J. 2011, 17, 1070810715 .

(72) Lappin, A. G.; Mcauley, A. The redox chemistry of nickel. In Advances In Inorganic Chemistry; Academic Press Inc., 1988; Vol. 32.

(73) D’Accriscio, F.; Borja, P.; Saffon-Merceron, N.; FustierBoutignon, M.; Mézailles, N.; Nebra, N. C-H Bond Trifluoromethylation of Arenes Enabled by a Robust, High-Valent $\mathrm{Ni}^{\mathrm{IV}}$ Complex. Angew. Chem., Int. Ed. 2017, 56, 12898-12902.

(74) Xu, H.; Diccianni, J. B.; Katigbak, J.; Hu, C.; Zhang, Y.; Diao, T. Bimetallic C-C Bond-Forming Reductive Elimination from Nickel. J. Am. Chem. Soc. 2016, 138, 4779-4786.

(75) Lee, C.-M.; Chiou, T.-W.; Chen, H.-H.; Chiang, C.-Y.; Kuo, T.S.; Liaw, W.-F. Mononuclear Ni ${ }^{\mathrm{II}}$-Thiolate Complexes with Pendant Thiol and Dinuclear $\mathrm{Ni}^{\mathrm{II} / \mathrm{II}}$-Thiolate Complexes with $\mathrm{Ni}$...Ni Interaction Regulated by the Oxidation Levels of Nickels and the Coordinated Ligands. Inorg. Chem. 2007, 46, 8913-8923.

(76) Hikichi, S.; Yoshizawa, M.; Sasakura, Y.; Komatsuzaki, H.; Moro-oka, Y.; Akita, M. Structural Characterization and Intramolecular Aliphatic C-H Oxidation Ability of $\mathrm{M}^{\mathrm{III}}(\mu-\mathrm{O})_{2} \mathrm{M}^{\mathrm{III}}$ Complexes of $\mathrm{Ni}$ and $\mathrm{Co}$ with the Hydrotris-(3,5-dialkyl-4-Xpyrazolyl)borate Ligands $\mathrm{Tp}^{\mathrm{Me} 2, \mathrm{X}}(\mathrm{X}=\mathrm{Me}, \mathrm{H}, \mathrm{Br})$ and $\mathrm{Tp}^{\mathrm{iPr} 2}$. Chem.-Eur. J. 2001, 7, 5011-5028.

(77) Diccianni, J. B.; Hu, C.; Diao, T. Binuclear, High-Valent Nickel Complexes: Ni-Ni Bonds in Aryl-Halogen Bond Formation. Angew. Chem. 2017, 129, 3689-3693.

(78) Zhou, W.; Watson, M. B.; Zheng, S.; Rath, N. P.; Mirica, L. M. Ligand Effects on the Properties of Ni(III) Complexes: AerobicallyInduced Aromatic Cyanation at Room Temperature. Dalton Trans. 2016, 45, 15886-15893.

(79) Ammann, C.; Meier, P.; Merbach, A. A simple Multinuclear NMR Thermometer. J. Magn. Reson. 1982, 46, 319-321.

(80) CrysAlis CCD 1.171.31.2 (release 07-07-2006), CrysAlis171.NET; Oxford Diffraction Ltd., 2006.

(81) CrysAlis RED 1.171.31.2 (release 07-07-2006), CrysAlis171.NET; Oxford Diffraction Ltd., 2006.

(82) Altomare, A.; Burla, M. C.; Camalli, M.; Cascarano, G. L.; Giacovazzo, C.; Guagliardi, A.; Moliterni, A. G. G.; Polidori, G.; Spagna, R. SIR97: a New Tool for Crystal Structure Determination and Refinement. J. Appl. Crystallogr. 1999, 32, 115-119.

(83) Sheldrick, G. M. SHELXTL, Version 2014/7; University of Göttingen, 2014.

(84) Nardelli, M. Parst: A System of Fortran Routines for Calculating Molecular Structure Parameters from Results of Crystal Structure Analyses. Comput. Chem. 1993, 7, 95-98.
(85) Farrugia, L. J. ORTEP-3 for Windows - a version of ORTEP-III with a Graphical User Interface (GUI). J Appl Cryst 1997, 30, 565.

(86) Frisch, M. J.; Trucks, G. W.; Schlegel, H. B.; Scuseria, G. E.; Robb, M. A.; Cheeseman, J. R.; Montgomery, J. J. A.; Vreven, T.; Kudin, K. N.; Burant, J. C.; Millam, J. M.; Iyengar, S. S.; Tomasi, J.; Barone, V.; Mennucci, B.; Cossi, M.; Scalmani, G.; Rega, N.; Petersson, G. A.; Nakatsuji, H.; Hada, M.; Ehara, M.; Toyota, K.; Fukuda, R.; Hasegawa, J.; Ishida, M.; Nakajima, T.; Honda, Y.; Kitao, O.; Nakai, H.; Klene, M.; Li, X.; Knox, J. E.; Hratchian, H. P.; Cross, J. B.; Adamo, C.; Jaramillo, J.; Gomperts, R.; Stratmann, R. E.; Yazyev, O.; Austin, A. J.; Cammi, R.; Pomelli, C.; Ochterski, J. W.; Ayala, P. Y.; Morokuma, K.; Voth, G. A.; Salvador, P.; Dannenberg, J. J.; Zakrzewski, V. G.; Dapprich, S.; Daniels, A. D.; Strain, M. C.; Farkas, O.; Malick, D. K.; Rabuck, A. D.; Raghavachari, K.; Foresman, J. B.; Ortiz, J. V.; Cui, Q.; Baboul, A. G.; Clifford, S.; Cioslowski, J.; Stefanov, B. B.; Liu, G.; Liashenko, A.; Piskorz, P.; Komaromi, I.; Martin, R. L.; Fox, D. J.; Keith, T.; Al-Laham, M. A.; Peng, C. Y.; Nanayakkara, A.; Challacombe, M.; Gill, P. M. W.; Johnson, B.; Chen, W.; Wong, M. W.; Gonzalez, C.; Pople, J. A. Gaussian09, Revision C.01; Gaussian, Inc.: Wallingford, CT, 2009.

(87) Casida, M. E.; Jamorski, C.; Casida, K. C.; Salahub, D. R. Molecular excitation energies to high-lying bound states from timedependent density-functional response theory: Characterization and correction of the time-dependent local density approximation ionization threshold. J. Chem. Phys. 1998, 108, 4439-4449.

(88) Perdew, J. P.; Burke, K.; Ernzerhof, M. Generalized Gradient Approximation Made Simple. Phys. Rev. Lett. 1996, 77, 3865-3868.

(89) Hay, P. J.; Wadt, W. R. Ab Initio Effective Core Potentials for Molecular Calculations. Potentials for the Transition Metal Atoms Sc to Hg. J. Chem. Phys. 1985, 82, 270-283.

(90) McLean, A. D.; Chandler, G. S. Contracted Gaussian basis sets for molecular calculations. I. Second row atoms, $Z=11-18$. J. Chem. Phys. 1980, 72, 5639-5648. 


\section{Halogen Bonding Interactions and}

\section{Electrochemical Properties of Unsymmetrical}

\section{Pyrazole Pincer NiII Halides: a Peculiar}

\section{Behaviour of the Fluoride Complex (PCN)NiF}

Lapo Luconi, ${ }^{a}$ Claudio Garino, ${ }^{b}$ Paolo Cerreia Vioglio, ${ }^{c}$ Roberto Gobetto, ${ }^{b}$ Michele R. Chierotti, ${ }^{b, *}$

Dmitry Yakhvarov, ${ }^{d, e, *}$ Zufar N. Gafurov, ${ }^{d, e}$ Vladimir Morozov, ${ }^{e}$ Il'yas Sakhapov, ${ }^{e}$ Andrea Rossin ${ }^{a, *}$ and Giuliano Giambastiani ${ }^{a, d, *}$

${ }^{a}$ Istituto di Chimica dei Composti Organometallici (ICCOM-CNR), Via Madonna del Piano 10, 50019 Sesto Fiorentino, Italy.

${ }^{b}$ Department of Chemistry and NIS Centre, University of Torino, V. Giuria 7, 10125, Torino, Italy.

${ }^{c}$ CNRS, Aix-Marseille Université, Institute de Chimie Radicalaire, Avenue Escadrille NormandieNiemen 521, 13397 Marseille, France

${ }^{d}$ Kazan Federal University, Kremlyovskaya str. 18, 420008 Kazan, Russia.

${ }^{e}$ Arbuzov Institute of Organic and Physical Chemistry, FRC Kazan Scientific Center of RAS, Arbuzov str. 8, 420088 Kazan, Russia

\section{Supporting Information}


Table S1. Selected bond distances $(\AA)$ and angles $\left(^{\circ}\right)$ for complexes 1-4. See Figure 1 in the main text for atom numbering. $\mathrm{X}=\mathrm{F}, \mathrm{Cl}, \mathrm{Br}, \mathrm{I}$.

\begin{tabular}{lcccc}
\hline & $\mathbf{1} \cdot \mathrm{H}_{2} \mathrm{O}$ & $\mathbf{2}$ & $\mathbf{3}$ & $\mathbf{4}$ \\
\hline $\mathrm{Ni}(1)-\mathrm{X}(1)$ & $1.8724(16)$ & $2.2322(16)$ & $2.3627(13)$ & $2.559(2)$ \\
$\mathrm{Ni}(1)-\mathrm{P}(1)$ & $2.1436(10)$ & $2.1677(15)$ & $2.1658(17)$ & $2.175(3)$ \\
$\mathrm{Ni}(1)-\mathrm{N}(1)$ & $1.903(2)$ & $1.919(4)$ & $1.924(5)$ & $1.923(9)$ \\
$\mathrm{Ni}(1)-\mathrm{C}(1)$ & $1.856(3)$ & $1.885(5)$ & $1.880(6)$ & $1.877(10)$ \\
$\mathrm{N}(1)-\mathrm{N}(2)$ & $1.372(3)$ & $1.361(5)$ & $1.358(7)$ & $1.390(12)$ \\
$\mathrm{X}(1)-\mathrm{Ni}(1)-\mathrm{N}(1)$ & $92.44(8)$ & $92.94(13)$ & $92.86(15)$ & $93.2(2)$ \\
$\mathrm{X}(1)-\mathrm{Ni}(1)-\mathrm{P}(1)$ & $100.33(6)$ & $101.45(6)$ & $101.45(6)$ & $101.62(10)$ \\
$\mathrm{C}(1)-\mathrm{Ni}(1)-\mathrm{N}(1)$ & $83.60(11)$ & $82.76(19)$ & $82.6(2)$ & $83.2(4)$ \\
$\mathrm{C}(1)-\mathrm{Ni}(1)-\mathrm{P}(1)$ & $83.63(9)$ & $83.24(15)$ & $83.62(19)$ & $82.8(3)$ \\
$\mathrm{N}(1)-\mathrm{Ni}(1)-\mathrm{P}(1)$ & $166.98(7)$ & $164.62(13)$ & $164.41(16)$ & $163.6(3)$ \\
$\mathrm{C}(1)-\mathrm{Ni}(1)-\mathrm{X}(1)$ & $176.05(10)$ & $174.18(15)$ & $173.48(18)$ & $172.7(3)$ \\
\hline
\end{tabular}
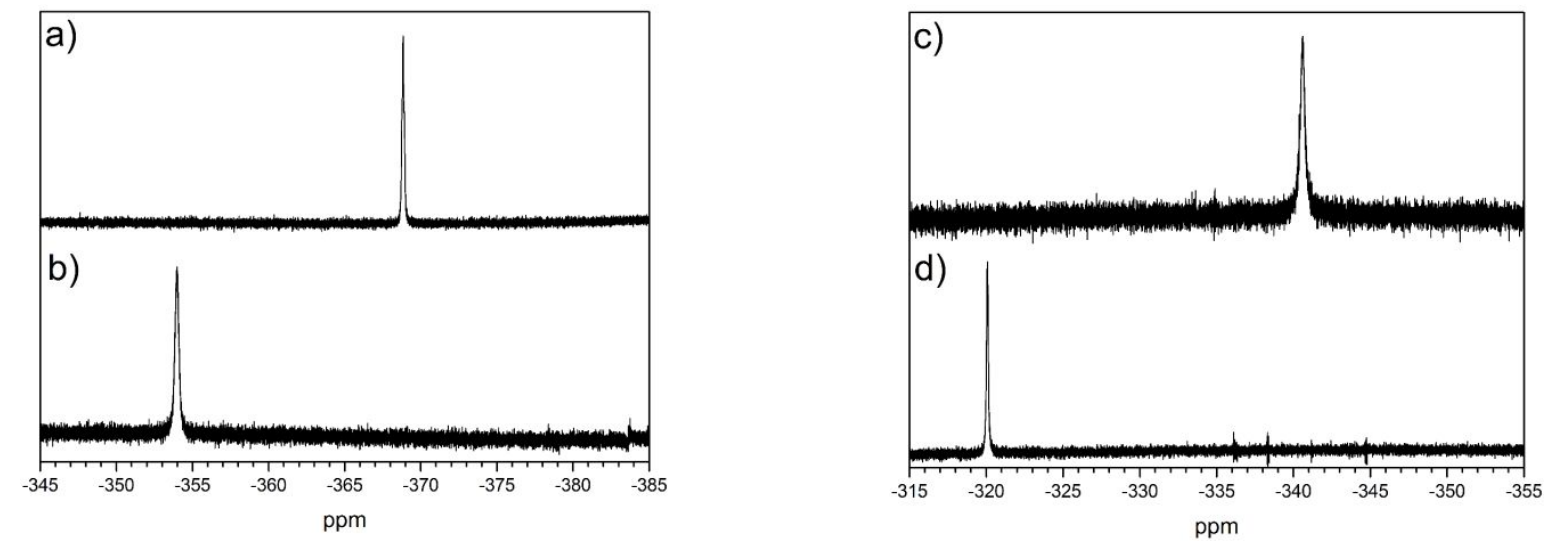

Figure S1. Plots of the fluoride region of the ${ }^{19} \mathrm{~F}$ NMR spectra of ( $\left.{ }^{\mathrm{B} u P C P}\right) \mathrm{NiF}$ (left) and 1 (right) at 233 $\mathrm{K}$ with increasing equivalents of IPFB in THF- $d_{\delta}$ (a) pure $\left({ }^{t B u P C P}\right) \mathrm{NiF}$; (b) $\left({ }^{t B u P C P}\right) \mathrm{NiF}$ with an excess of IPFB; (c) pure 1; (d) 1 with an excess of IPFB. 


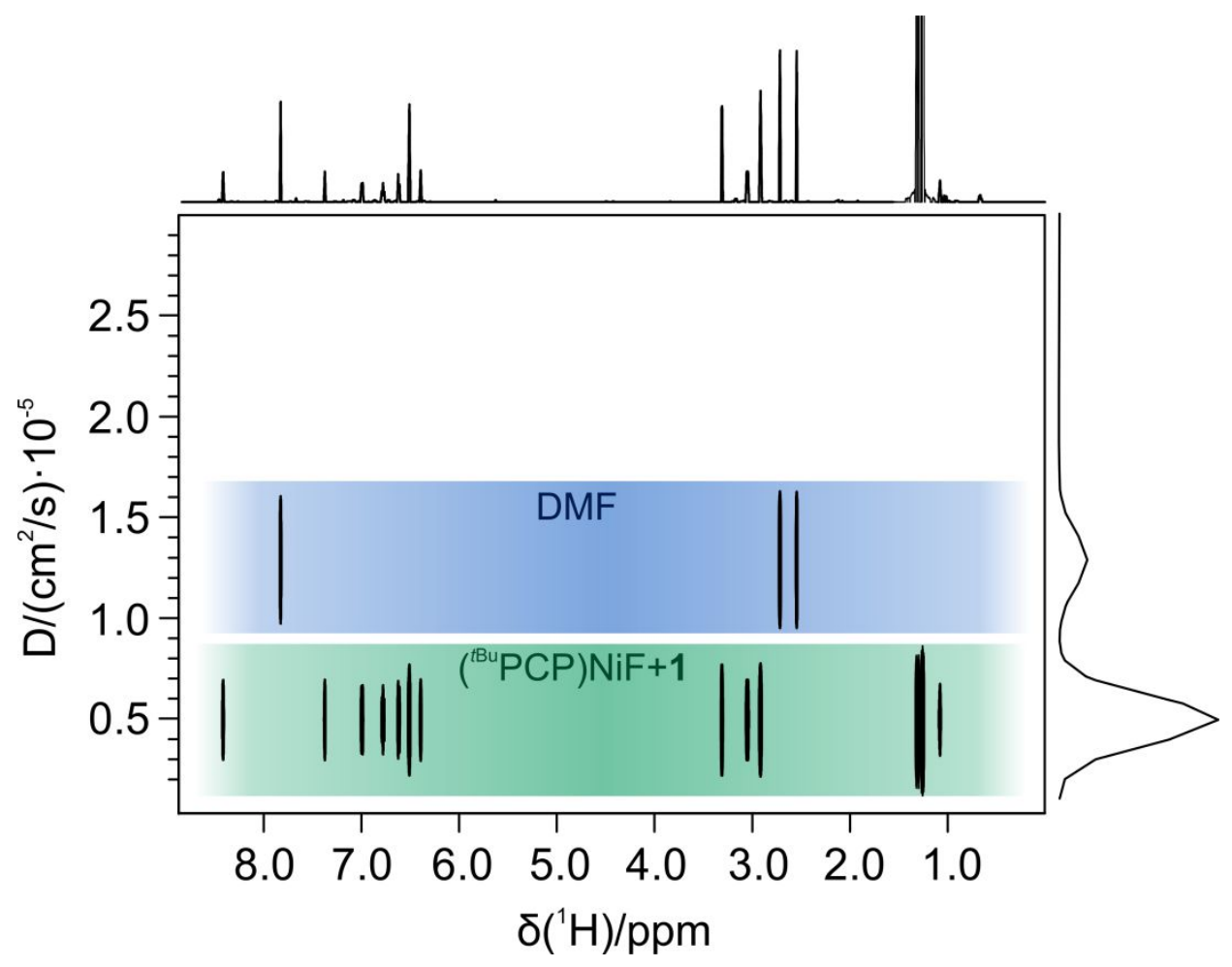

Figure S2. 2D DOSY NMR measurement of an equimolar solution of (BBuPCP)NiF and 1 in DMF- $d_{7}$. The horizontal axis represents chemical shifts, whereas the vertical axis diffusion coefficients; the dark spots are the resonances of the solution components spread in the second dimension according to their measured diffusion coefficient.

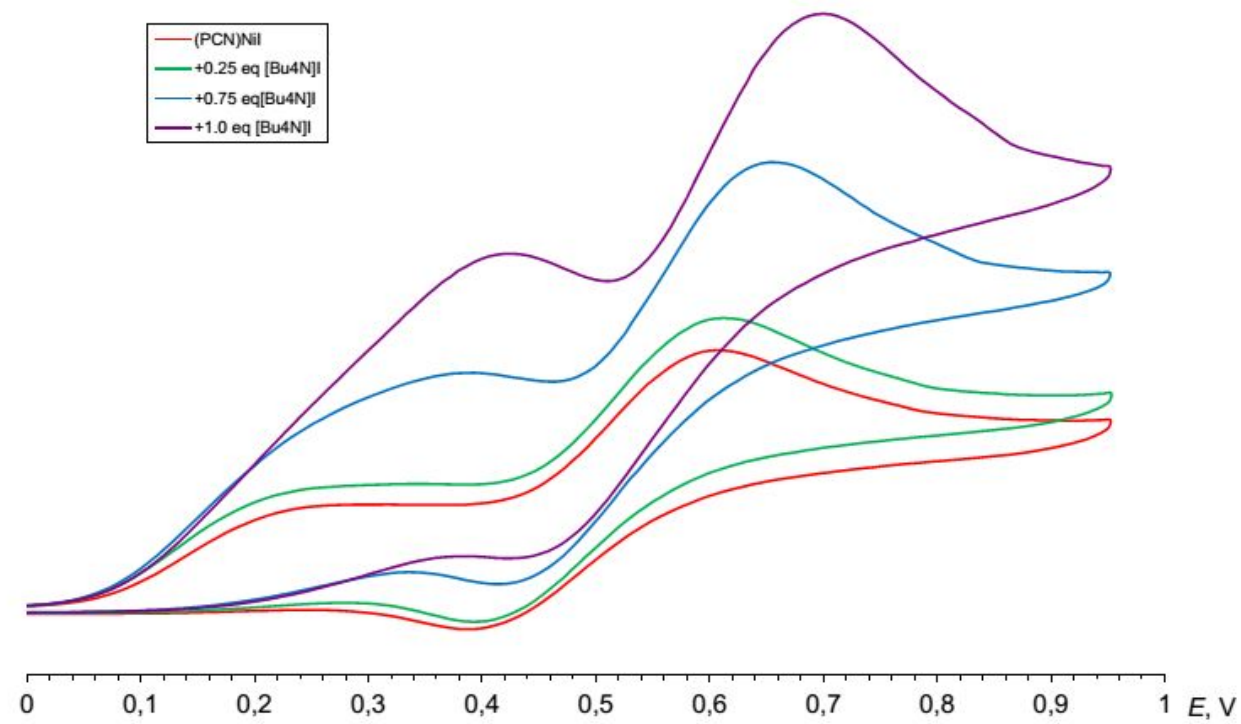

Figure S3. CV curves of $4\left[5 \cdot 10^{-3} \mathrm{M}\right]$ in the presence of increasing amounts of tetrabutylammonium iodide (TBAI). The $\mathrm{CV}$ curves were recorded in the presence of $\left(\mathrm{NBu}_{4}\right) \mathrm{BF}_{4}\left[10^{-1} \mathrm{M}\right]$ without IR compensation at the first scan at constant potential scan rate $50 \mathrm{mV} \cdot \mathrm{s}^{-1}(\mathrm{GC}$ working electrode, $\mathrm{T}=293 \mathrm{~K})$. Peak potentials are referred to $\mathrm{Ag} / \mathrm{AgNO}_{3}, 0.01 \mathrm{M}$ in $\mathrm{CH}_{3} \mathrm{CN}$ reference electrode. 
Table S2. EPR data details.

\begin{tabular}{|l|c|c|c|c|c|}
\hline & $\mathbf{E}_{\mathbf{0 . 5}}$ & $\begin{array}{c}\text { Line width of main } \\
\text { signal }\end{array}$ & $\begin{array}{c}\text { g-factor of the main } \\
\text { signal }\end{array}$ & $\begin{array}{c}\text { Line width of } \\
\text { the second } \\
\text { signal }\end{array}$ & $\begin{array}{c}\text { g-factor of } \\
\text { the second } \\
\text { signal }\end{array}$ \\
\hline $\mathbf{F}$ & $1,5 \mathrm{~V}$ & $62 \mathrm{G}$ & 2.188 & - & - \\
\hline $\mathbf{C l}$ & $0,8 \mathrm{~V}$ & $60 \mathrm{G}$ & 2.177 & $75 \mathrm{G}$ & 2.24 \\
\hline $\mathbf{B r}$ & $0,8 \mathrm{~V}$ & $27 \mathrm{G} ; 31 \mathrm{G} ; 39 \mathrm{G} ; 48 \mathrm{G}$ & 2.150 & $75 \mathrm{G}$ & 2.24 \\
\hline $\mathbf{I}$ & $0,5 \mathrm{~V}$ & $62 \mathrm{G}$ & 2.188 & - & - \\
\hline
\end{tabular}

\section{Comparison of experimental and simulated EPR spectra for complexes 1-4.}

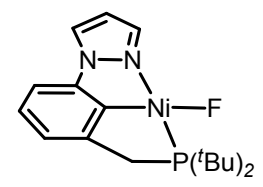

1

Winsim v.1.0, 2002

Public EPR Soltware Tools

Thealth Sciences

National Institutes of Health, USA

htpp:/lepr.niehs.nih.gowt

Spectral Parameters:

Field Center: $3105.400 \mathrm{G}$

Scan Range: $1001.600 \mathrm{C}$

Data Points: 4096

$\begin{array}{ll}\text { Mod. Amp:: } & \mathrm{G} \\ \text { Mod. Freq: } & \mathrm{KHz}\end{array}$

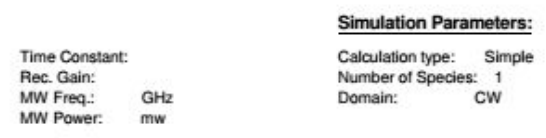

Species number: 1

Lorentzian : 91.551

Line width : 61.355 G G-shim

G-shitt : $: 28.281$

MW Power:

Comment: eprdata

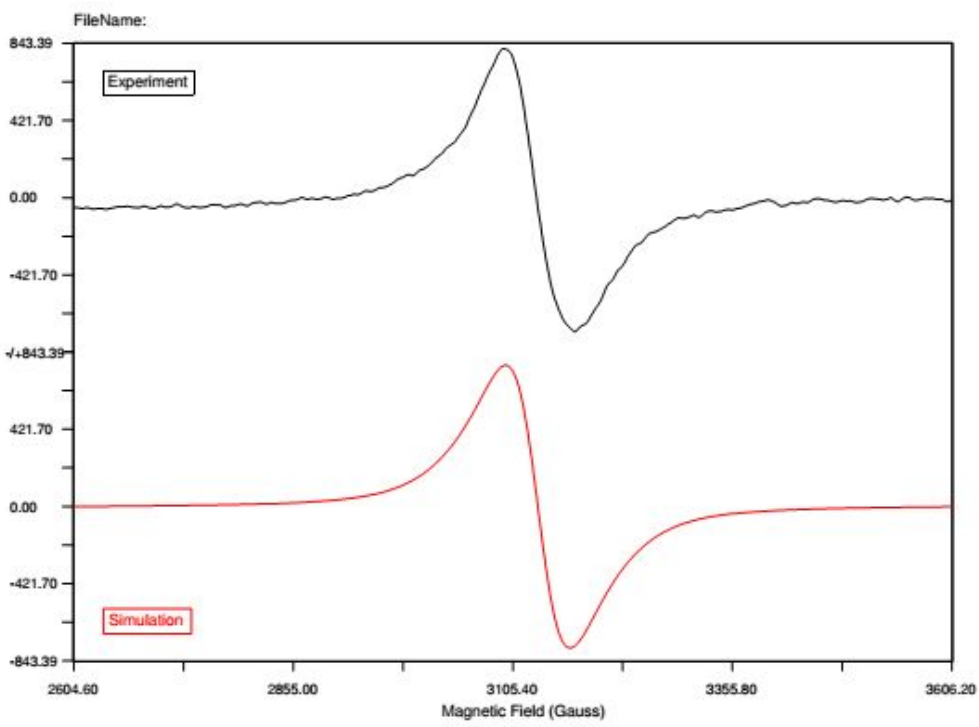

Figure S4. 


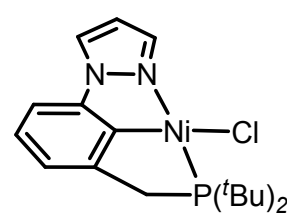

2

Winsim v.1.0, 2002

Public EPR Sotware Tools

National Institue Environmental Health Sciences

National Institutes of Health, USA

http:llepr.niehs.nih.gowi

Spectral Parameters:

Field Center: $3106.226 \mathrm{G}$

Scan Range: $999.756 \mathrm{C}$

Data Points: $a^{4096}$

Time Constant:

Rec. Gain:

MW Power: $\quad$ GH

Simulation Parameters:

Calculation type: Simple

Number of Species: 22

come

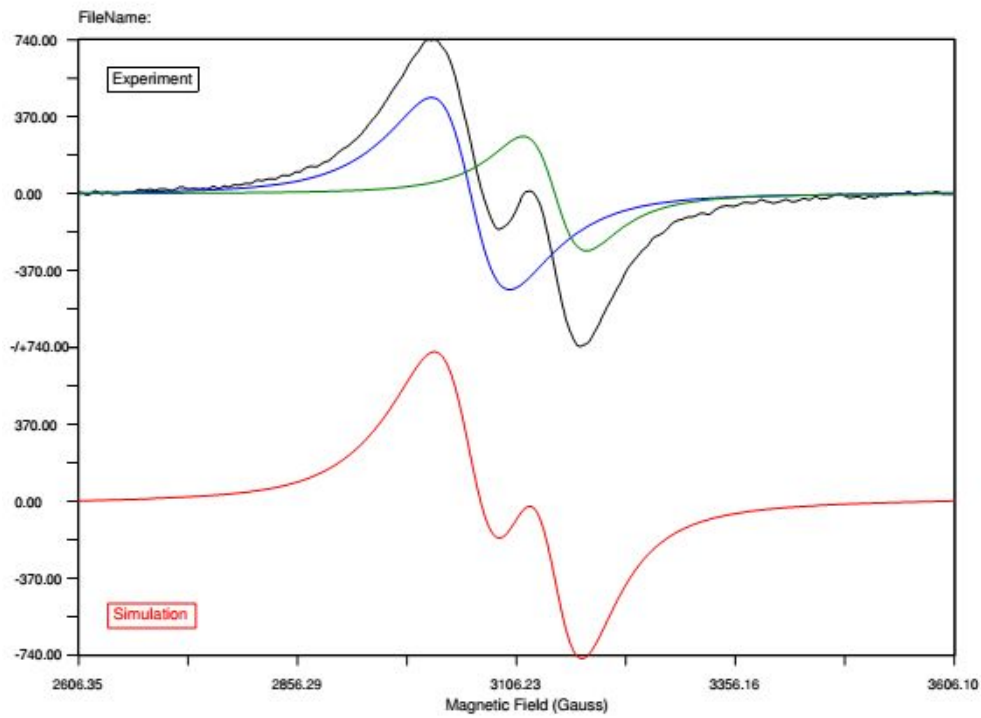

Figure S5.

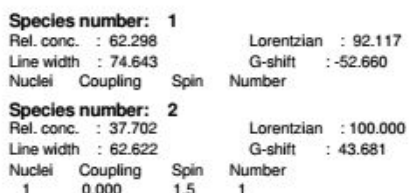

Nuclei Coupling Spin Number 


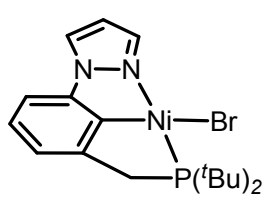

3

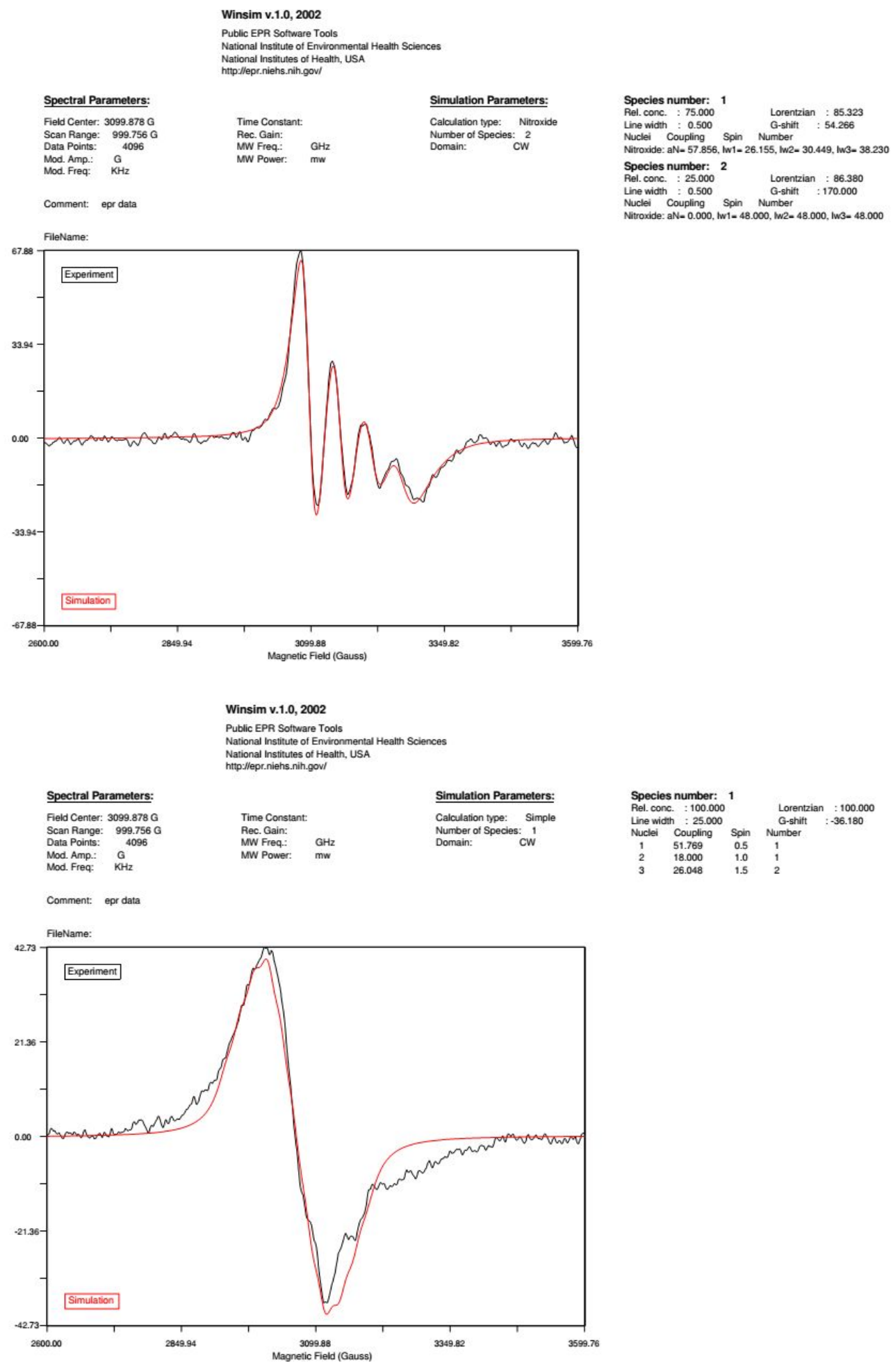

Winsim v.1.0, 2002

Spectral Parameters:

Time Constant:

ec. Gain:

imulation Parameters:

Number of Species: 2

Rel. conc.: $75.000 \quad$ Lorentzian : 85.323 Whe widith : $0.500 \quad$ G-shift $\quad: 54.266$ Nitroxide: aN= 57.856, iw1 $=26.155$, W22- 30.449, Iw3 38.230 Species number: 2 Nuclei Coupling Spin Number Comment: epr 


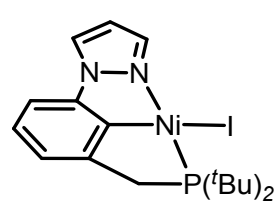

4

\section{Winsim v.1.0, 2002}

Public EPR Software Tools

onmental Heath Sclences

National Institutes of Health, USA

Spectral Parameters:

Field Center: $3106.250 \mathrm{G}$

Scan Range: 1001.900

$\begin{array}{ll}\text { Mod. Amp:: } & G \\ \text { Mod. Freq: } & \mathrm{KHz}\end{array}$

Comment: epr data

FileName:

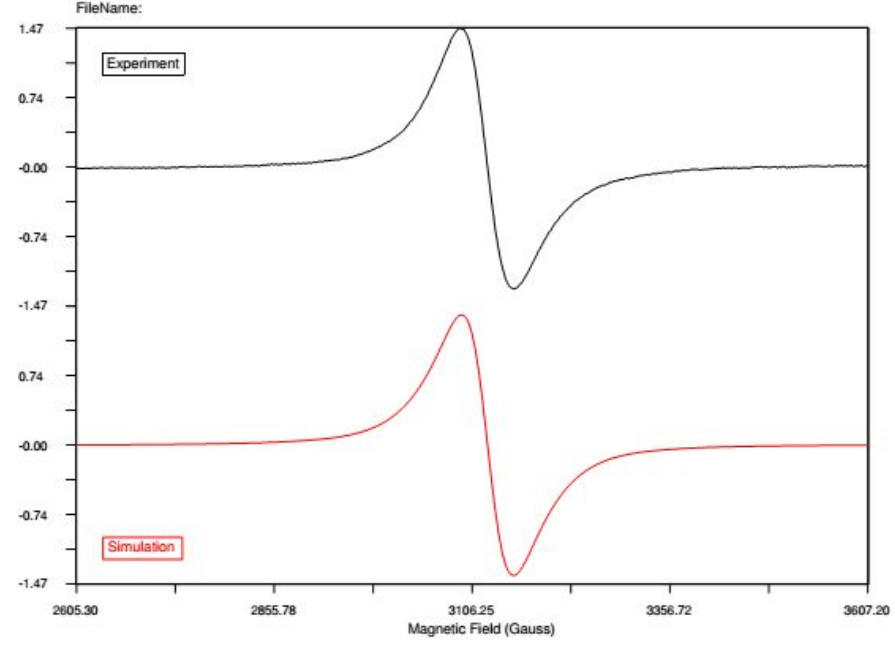

Figure S7.

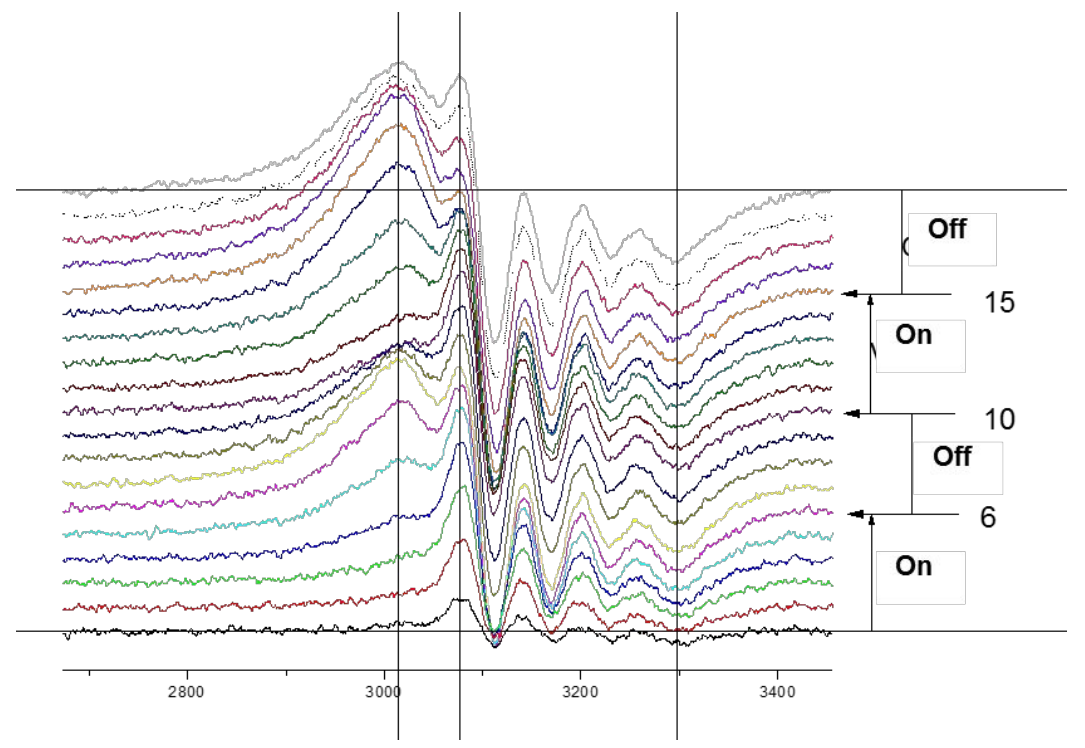


Figure S8. Monitoring of the oxidation process of complex $3\left[5 \cdot 10^{-3} \mathrm{M}\right]$ using in situ EPR spectro-electrochemistry in DMF in the presence of $\left(\mathrm{NBu}_{4}\right) \mathrm{BF}_{4}$ $\left[10^{-1} \mathrm{M}\right]$. On - current is on, Off - current is off. Time dependence plot.

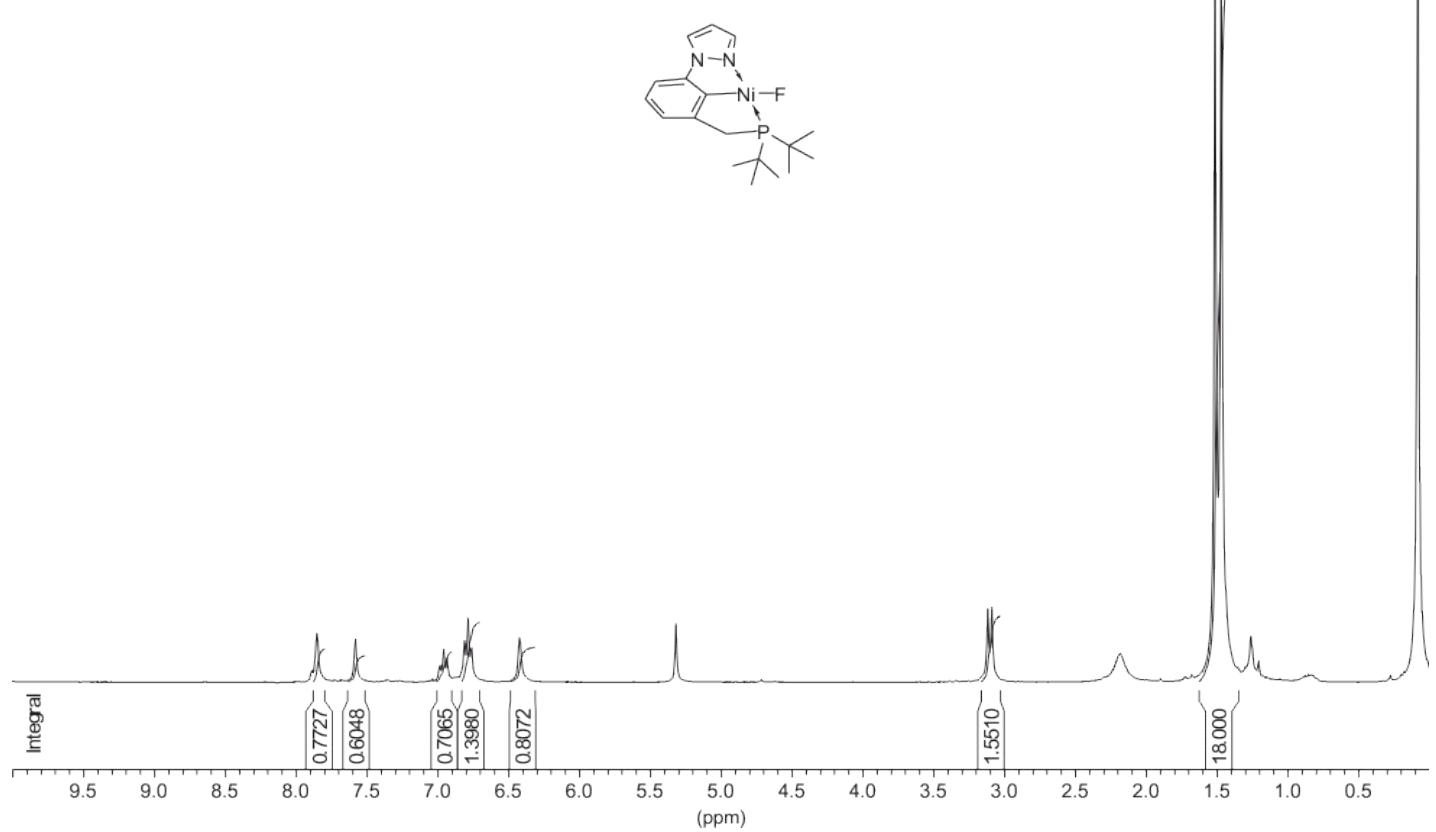

Figure S9. ${ }^{1} \mathrm{H}-\mathrm{NMR}$ spectrum $\left(300 \mathrm{MHz}, \mathrm{CD}_{2} \mathrm{Cl}_{2}, 298 \mathrm{~K}\right)$ of 1 . 


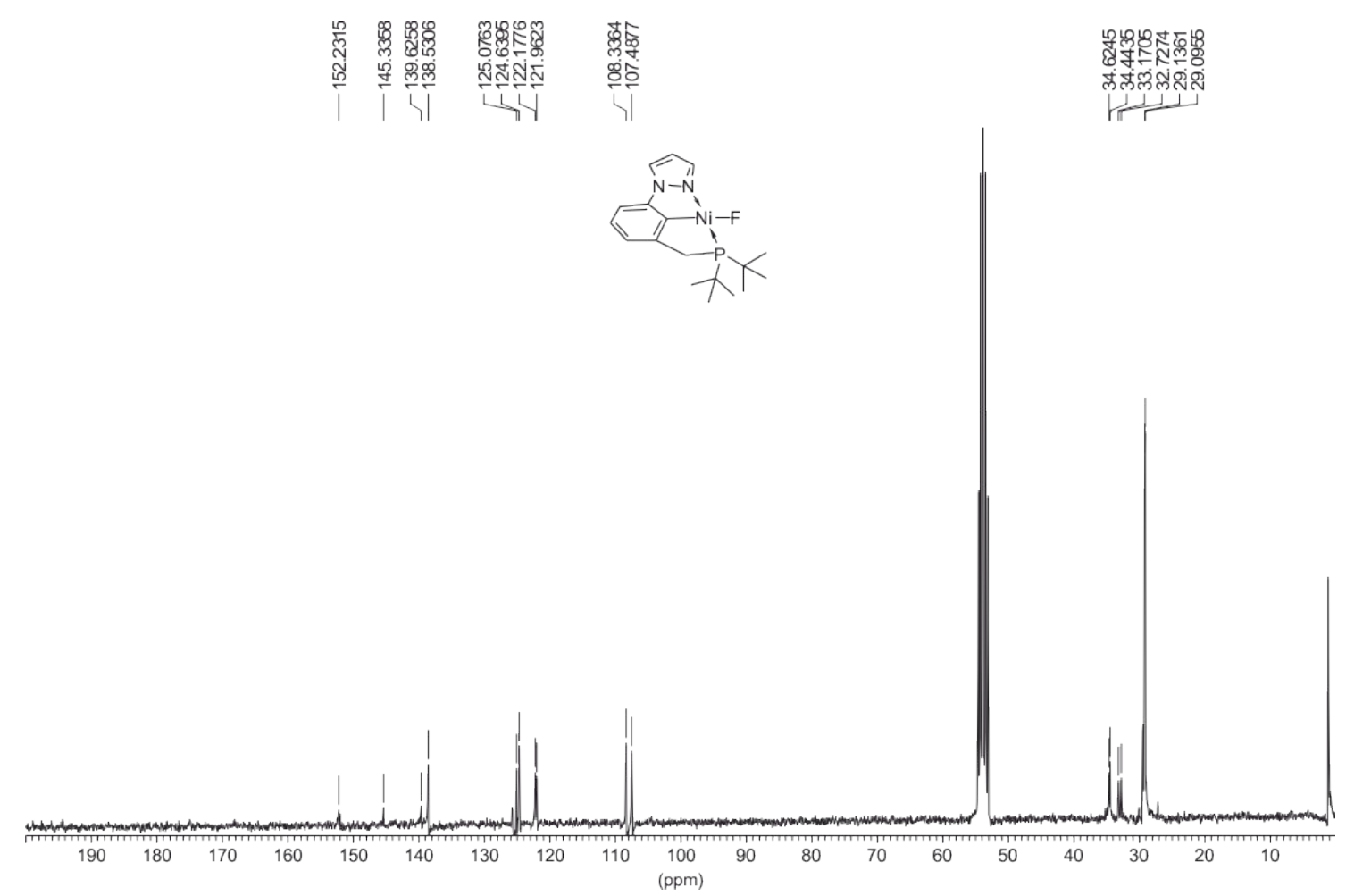

Figure S10. ${ }^{13} \mathrm{C}\left\{{ }^{1} \mathrm{H}\right\}-\mathrm{NMR}$ spectrum (75 MHz, $\left.\mathrm{CD}_{2} \mathrm{Cl}_{2}, 298 \mathrm{~K}\right)$ of 1.
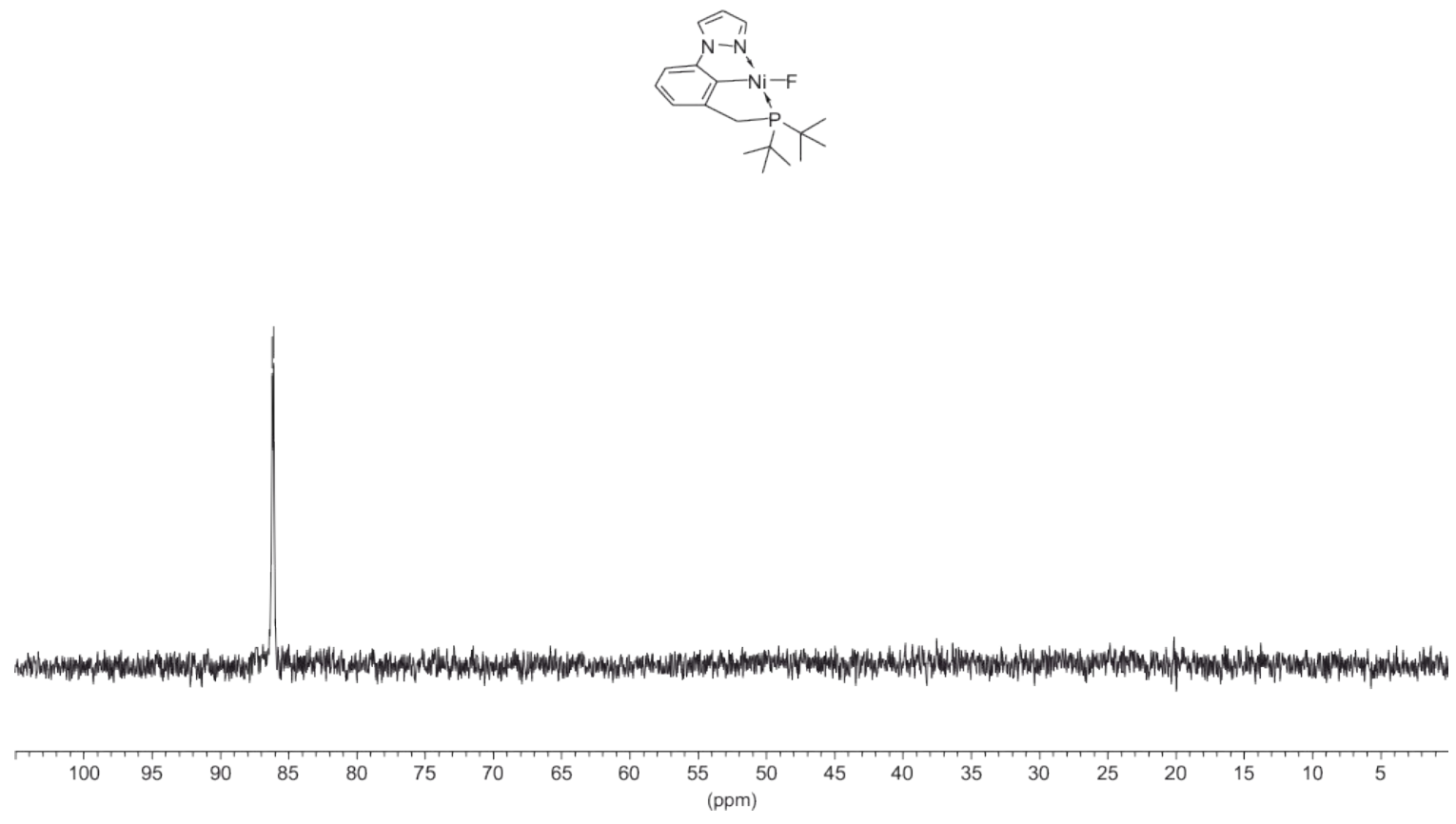

Figure S11. ${ }^{31} \mathrm{P}\left\{{ }^{1} \mathrm{H}\right\}-\mathrm{NMR}$ spectrum (121 MHz, $\mathrm{CD}_{2} \mathrm{Cl}_{2,}$ 298K) of 1. 


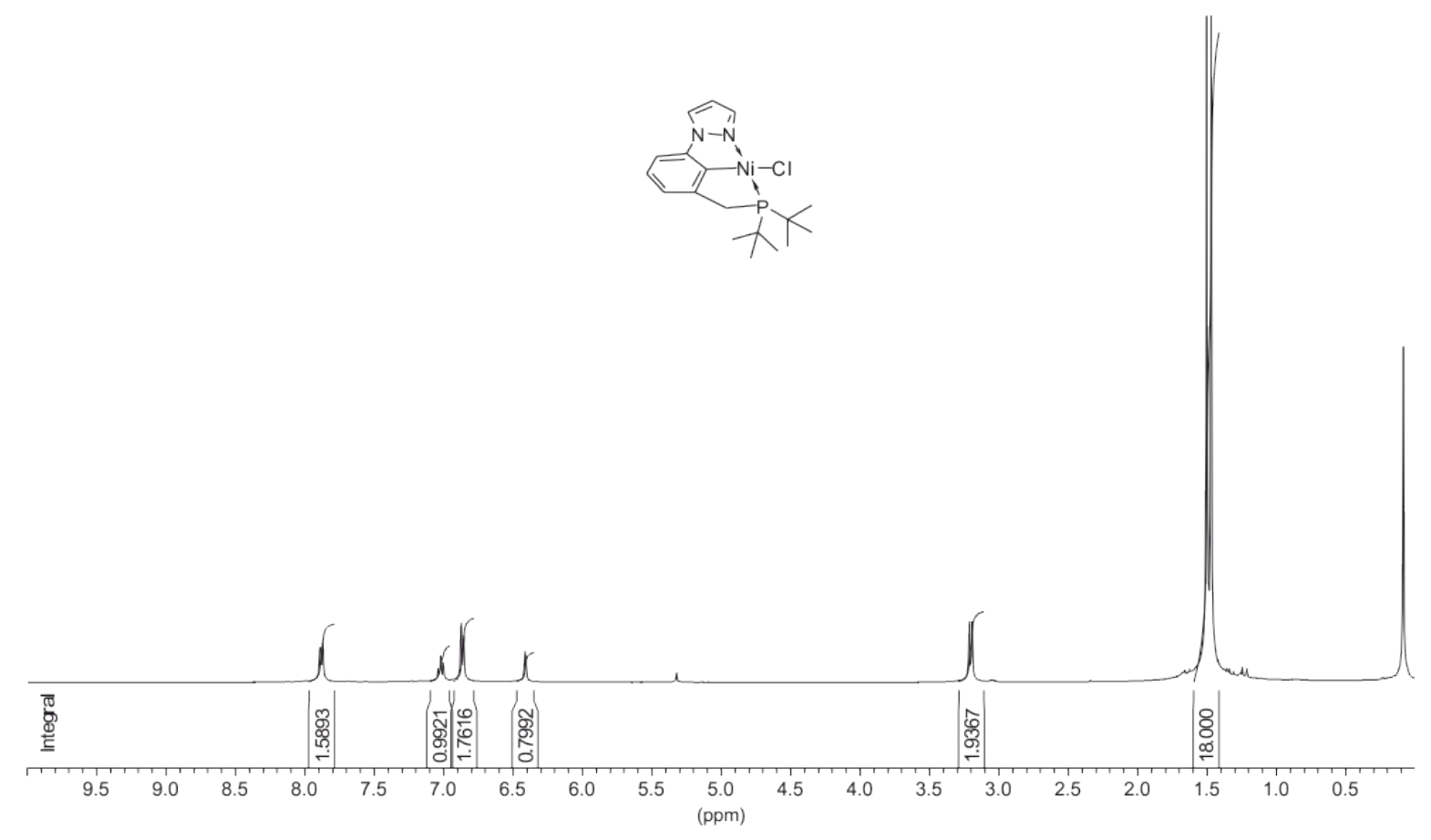

Figure S12. ${ }^{1} \mathrm{H}-\mathrm{NMR}$ spectrum $\left(400 \mathrm{MHz}, \mathrm{CD}_{2} \mathrm{Cl}_{2}, 298 \mathrm{~K}\right)$ of 2.

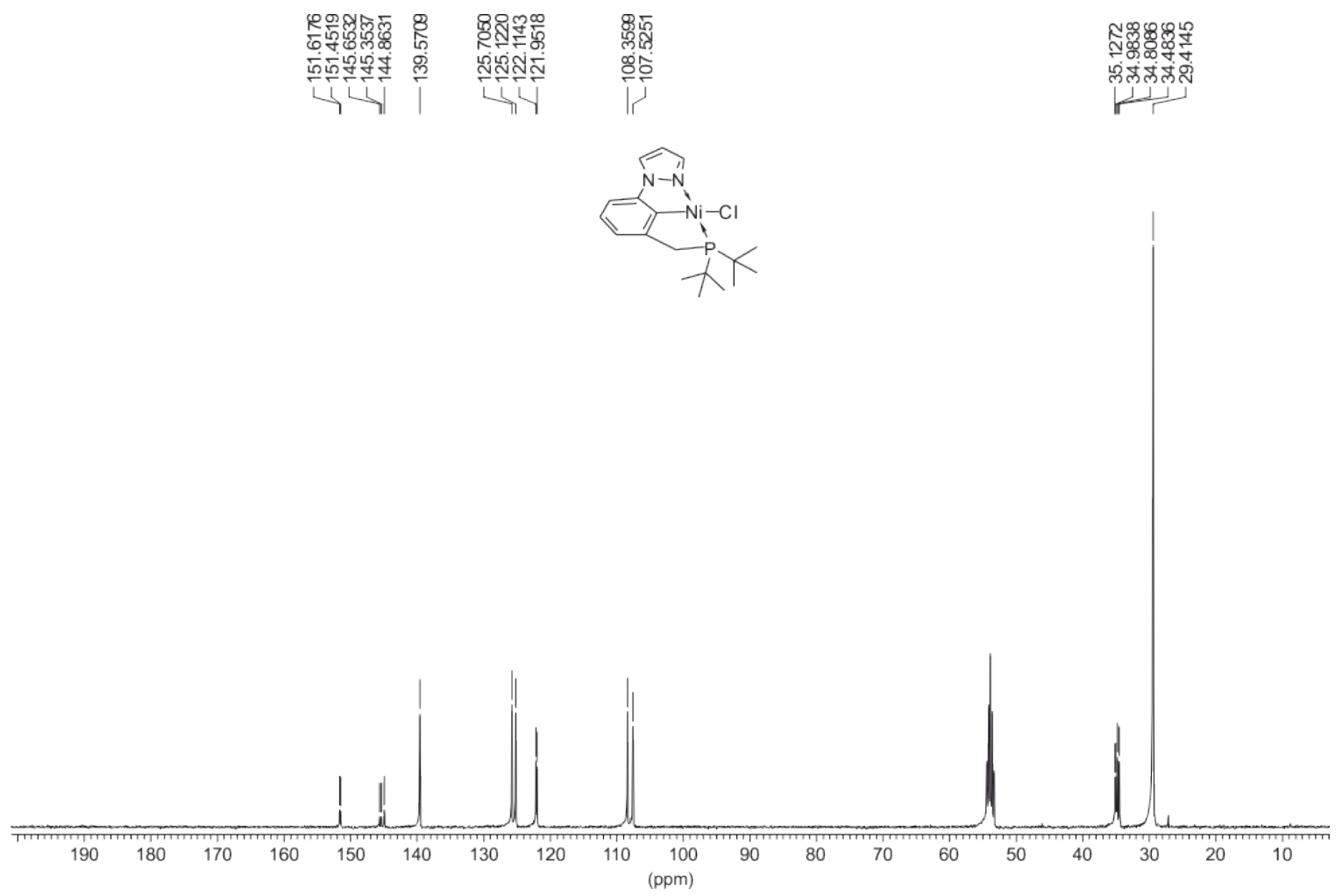


Figure S13. ${ }^{13} \mathrm{C}\left\{{ }^{1} \mathrm{H}\right\}-\mathrm{NMR}$ spectrum $\left(100 \mathrm{MHz}, \mathrm{CD}_{2} \mathrm{Cl}_{2}, 298 \mathrm{~K}\right)$ of 2.

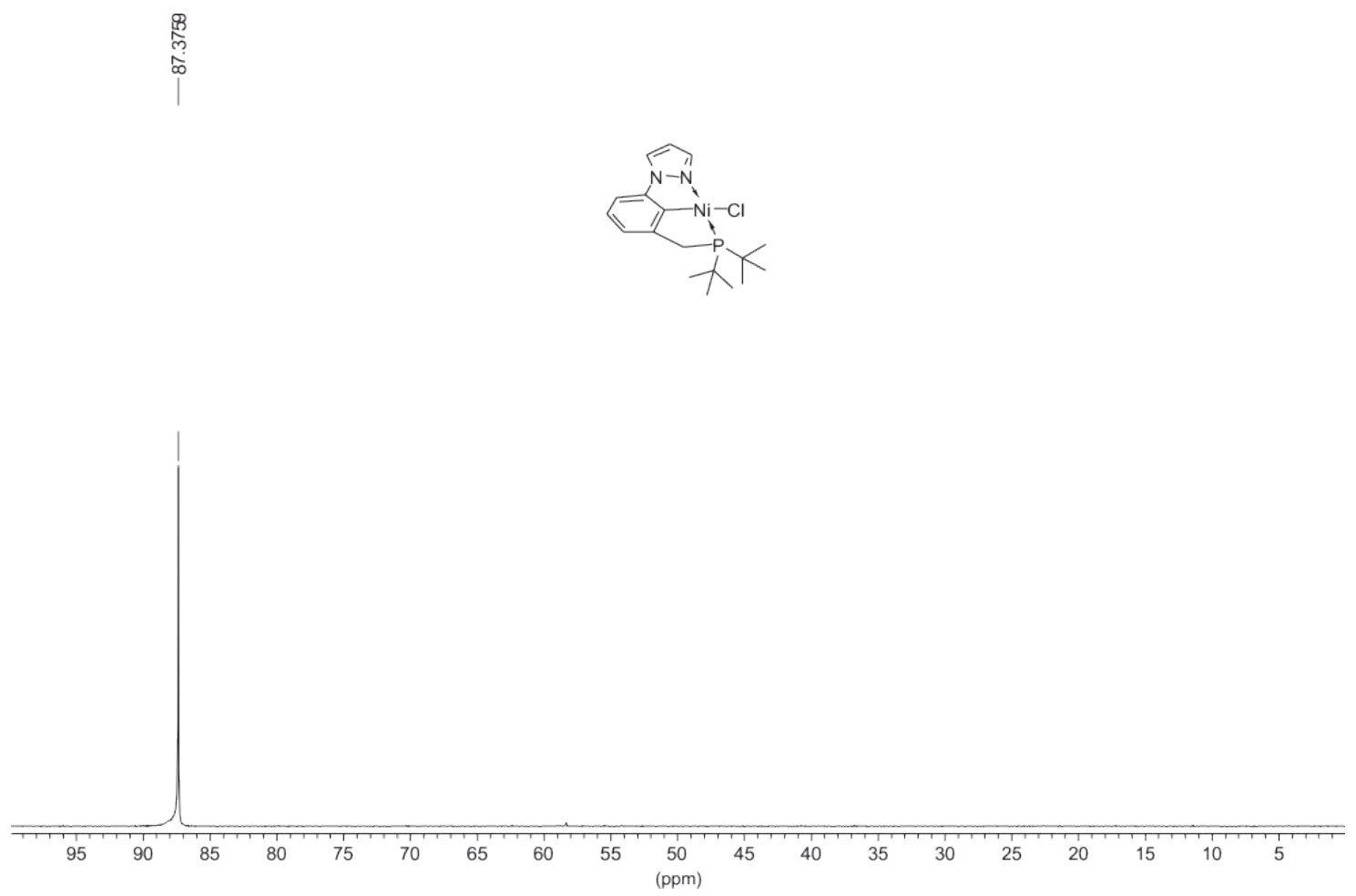

Figure S14. ${ }^{31} \mathrm{P}\left\{{ }^{1} \mathrm{H}\right\}-\mathrm{NMR}$ spectrum $\left(161 \mathrm{MHz}, \mathrm{CD}_{2} \mathrm{Cl}_{2}, 298 \mathrm{~K}\right)$ of $\mathbf{2}$.

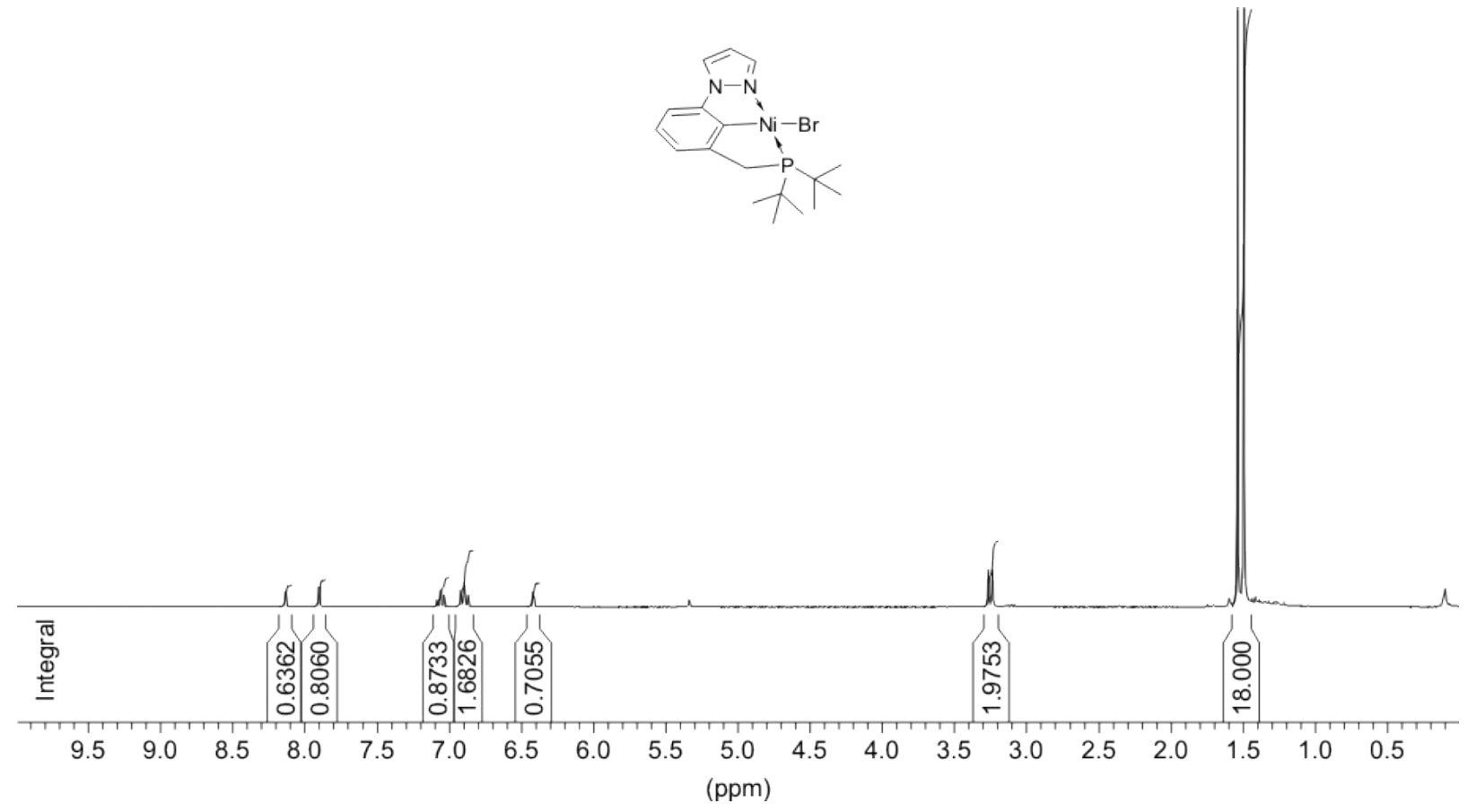

Figure S15. ${ }^{1} \mathrm{H}-\mathrm{NMR}$ spectrum $\left(300 \mathrm{MHz}, \mathrm{CD}_{2} \mathrm{Cl}_{2}, 298 \mathrm{~K}\right)$ of $\mathbf{3}$. 


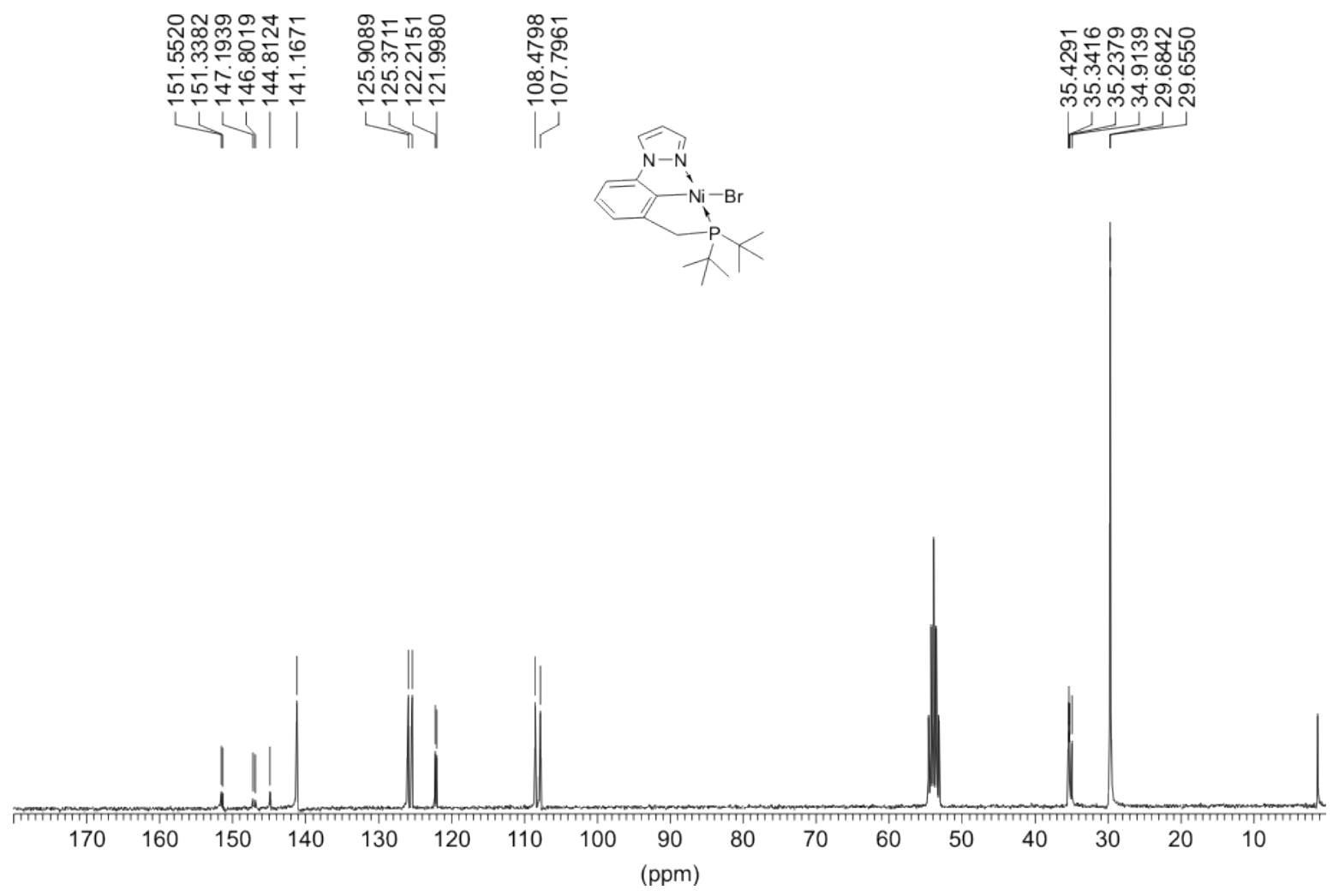

Figure S16. ${ }^{13} \mathrm{C}\left\{{ }^{1} \mathrm{H}\right\}-\mathrm{NMR}$ spectrum $\left(75 \mathrm{MHz}, \mathrm{CD}_{2} \mathrm{Cl}_{2}, 298 \mathrm{~K}\right)$ of $\mathbf{3}$.

$\underset{\substack{\stackrel{5}{*} \\ \infty \\ \infty \\ \infty}}{\infty}$
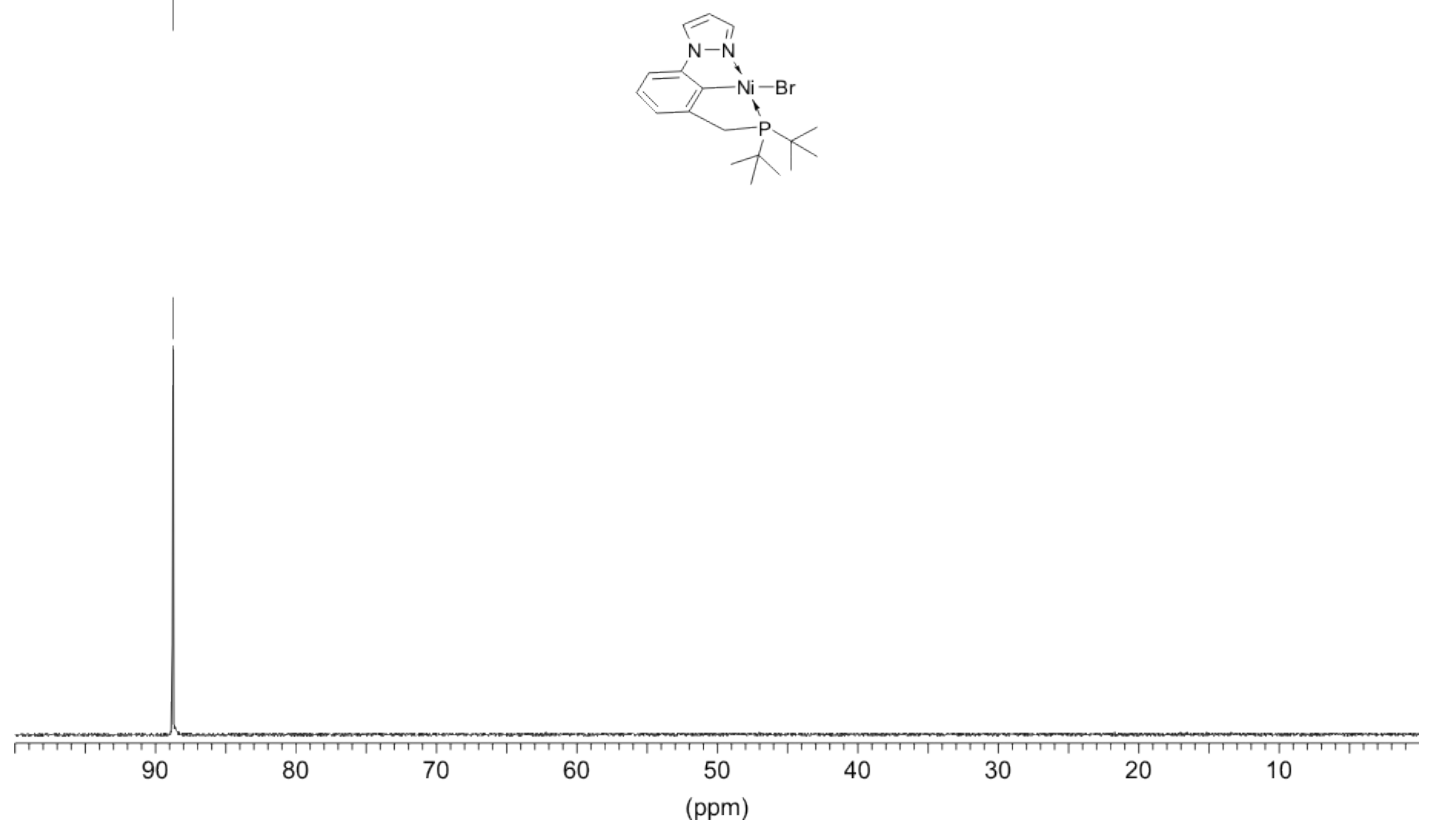

Figure S17. ${ }^{31} \mathrm{P}\left\{{ }^{1} \mathrm{H}\right\}-\mathrm{NMR}$ spectrum $\left(121 \mathrm{MHz}, \mathrm{CD}_{2} \mathrm{Cl}_{2}, 298 \mathrm{~K}\right)$ of 3. 


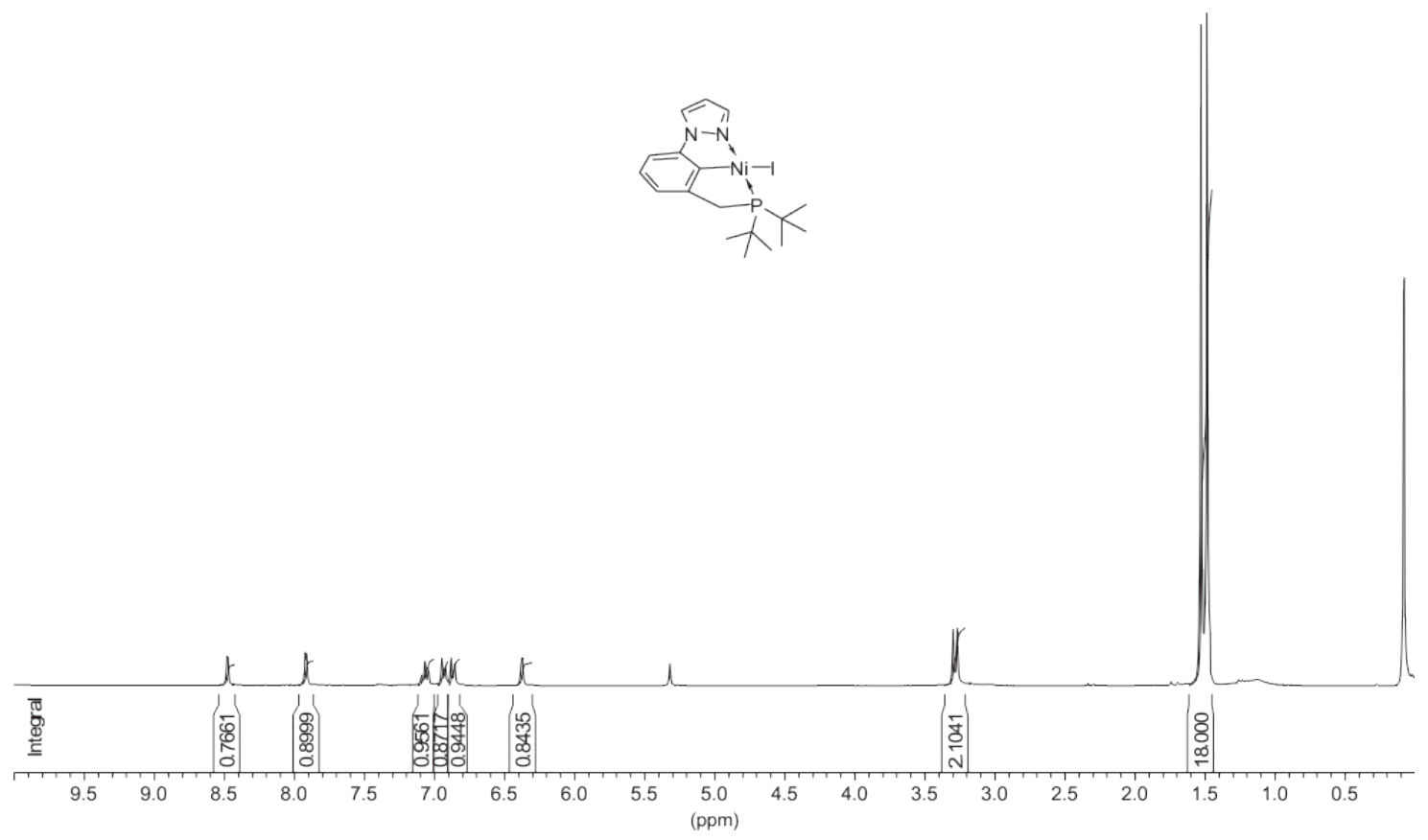

Figure S18. ${ }^{1} \mathrm{H}-\mathrm{NMR}$ spectrum $\left(300 \mathrm{MHz}, \mathrm{CD}_{2} \mathrm{Cl}_{2}, 298 \mathrm{~K}\right)$ of 4.

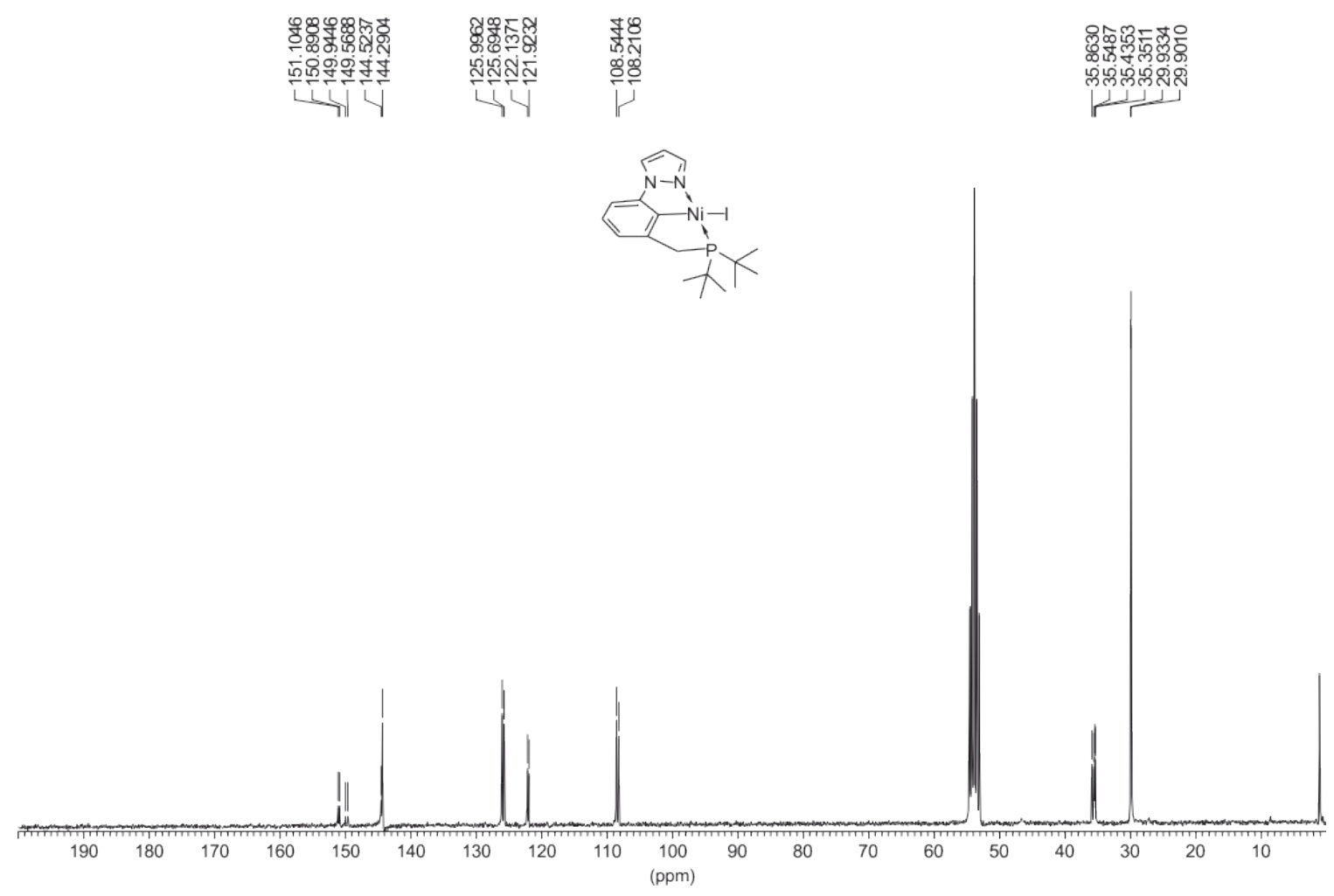

Figure S19. ${ }^{13} \mathrm{C}\left\{{ }^{1} \mathrm{H}\right\}-\mathrm{NMR}$ spectrum $\left(75 \mathrm{MHz}, \mathrm{CD}_{2} \mathrm{Cl}_{2}, 298 \mathrm{~K}\right)$ of 4 . 


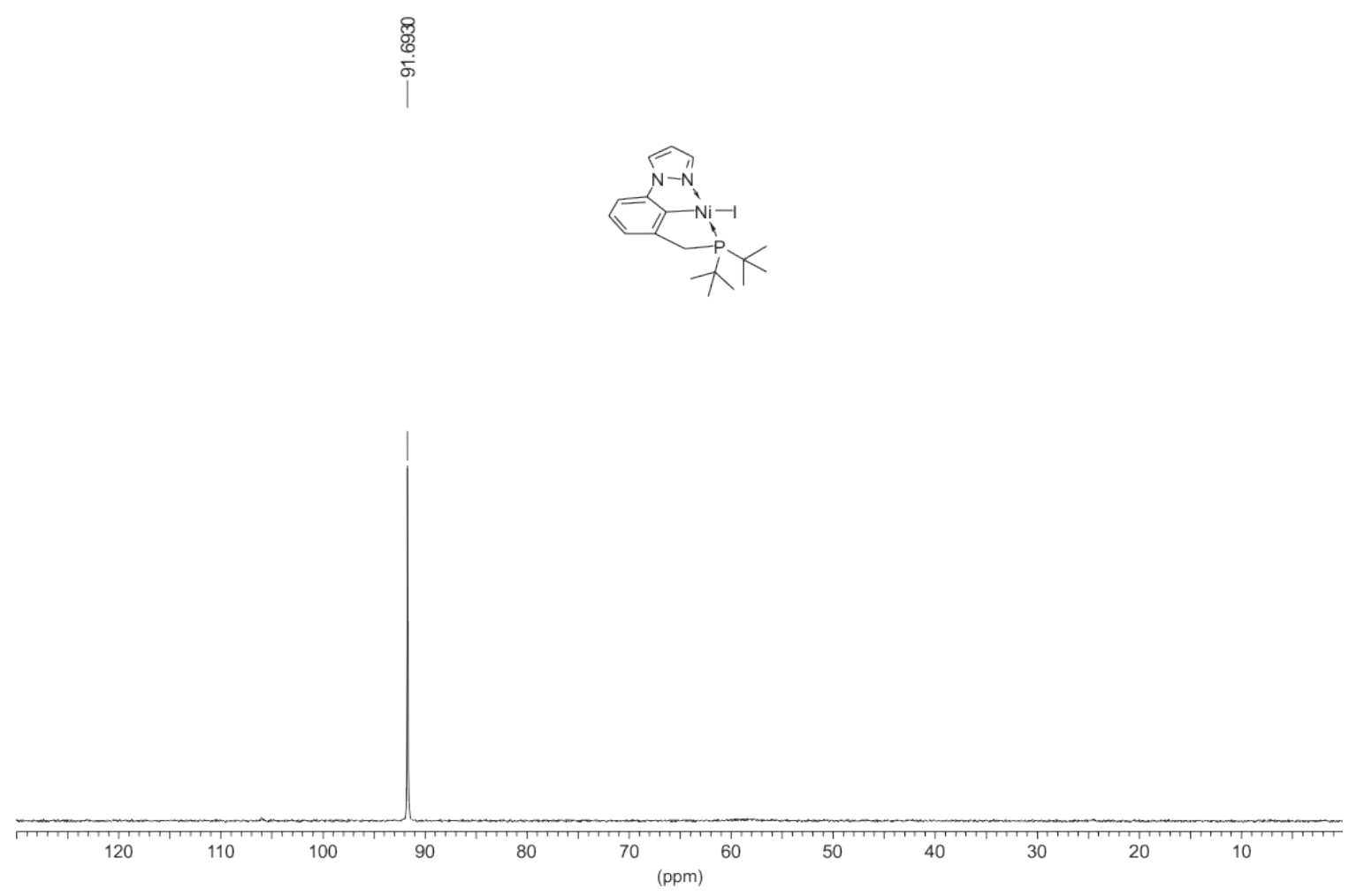

Figure S20. ${ }^{31} \mathrm{P}\left\{{ }^{1} \mathrm{H}\right\}-\mathrm{NMR}$ spectrum $\left(121 \mathrm{MHz}, \mathrm{CD}_{2} \mathrm{Cl}_{2}, 298 \mathrm{~K}\right)$ of 4. 